Andrews University

Digital Commons @ Andrews University

\title{
A Leadership Model for Initiating Change in the Seventh-day Adventist Church in Zambia
}

Edwin Shimunzhila

Andrews University

Follow this and additional works at: https://digitalcommons.andrews.edu/dmin

Part of the Practical Theology Commons

\section{Recommended Citation}

Shimunzhila, Edwin, "A Leadership Model for Initiating Change in the Seventh-day Adventist Church in Zambia" (2011). Professional Dissertations DMin. 522.

https://dx.doi.org/10.32597/dmin/522

https://digitalcommons.andrews.edu/dmin/522

This Project Report is brought to you for free and open access by the Graduate Research at Digital Commons @ Andrews University. It has been accepted for inclusion in Professional Dissertations DMin by an authorized administrator of Digital Commons @ Andrews University. For more information, please contact repository@andrews.edu. 
ABSTRACT

A LEADERSHIP MODEL FOR INITIATING CHANGE IN THE SEVENTH-DAY ADVENTIST CHURCH IN ZAMBIA

by

Edwin Shimunzhila

Adviser: Zebron Ncube 


\author{
ABSTRACT OF GRADUATE STUDENT RESEARCH \\ Project Dissertation \\ Andrews University \\ Seventh-day Adventist Theological Seminary
}

Title: A LEADERSHIP MODEL FOR INITIATING CHANGE IN THE SEVENTHDAY ADVENTIST CHURCH IN ZAMBIA

Name of researcher: Edwin Shimunzhila

Name and degree of faculty adviser: Zebron Ncube, DMin

Date completed: July 2011

\title{
Topic
}

The task of this project dissertation is to develop a leadership model for initiating and effecting change in the Seventh-day Adventist Church in Zambia.

\section{Purpose}

The purpose of this project dissertation is to develop a leadership model for the successful initiation and effecting of change in the Seventh-day Adventist Church in 
Zambia. Strategies will be developed that will help pastors and lay leaders facilitate the successful initiation of change.

\section{Sources}

The research method I chose to use in this dissertation is theoretical. Extracting information from what other scholars have written on change and the change process will be presented in the Zambian context. This method considers current and relevant information from books, articles, journals, online data, and available data from the Zambia Union Conference.

The process will include the following:

1. A theological reflection on initiating change will center on three biblical themes including (a) the Joseph and Moses methods of initiating change; (b) Jesus, Peter, and Paul initiating change across racial barriers; and (c) initiating change as understood in the writings of Ellen G. White.

2. A current review of literature contributes to a successful initiation of change. This will include anthropological literature on Zambian culture, which will help pastors and elders when initiating change.

3. I will discuss an analysis of leadership and church growth in Zambia. I will discuss the development of intervention tools and strategies for initiating change.

\section{Conclusions}

Both the Old and New Testaments provide leaders who exemplified leadership qualities that help pastors and lay leaders when initiating change. Change is inevitable because communities, governments, and businesses are changing. The church is not static 
but changes over time. Culture plays a critical role when initiating change. Formulating of strategies and skills to enable the twenty-first century pastor and lay leader to initiate successful change. 
Andrews University

Seventh-day Adventist Theological Seminary

\title{
A LEADERSHIP MODEL FOR INITIATING CHANGE IN THE SEVENTH-DAY ADVENTIST CHURCH IN ZAMBIA
}

\author{
A Project Dissertation \\ Presented in Partial Fulfillment \\ of the Requirements for the Degree \\ Doctor of Ministry
}

by

Edwin Shimunzhila

July 2011 
(C) Copyright by Edwin Shimunzhila 2011

All Rights Reserved 


\title{
A LEADERSHIP MODEL FOR INITIATING CHANGE IN THE
}

\section{SEVENTH-DAY ADVENTIST CHURCH IN ZAMBIA}

A project dissertation presented in partial fulfillment of the requirements for the degree

Doctor of Ministry

\author{
By
}

Edwin Shimunzhila

APPROVAL BY THE COMMITTEE:

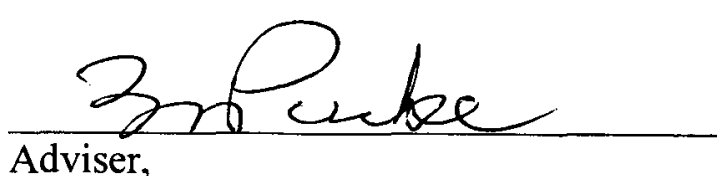

Adviser,

Zebron Ncube
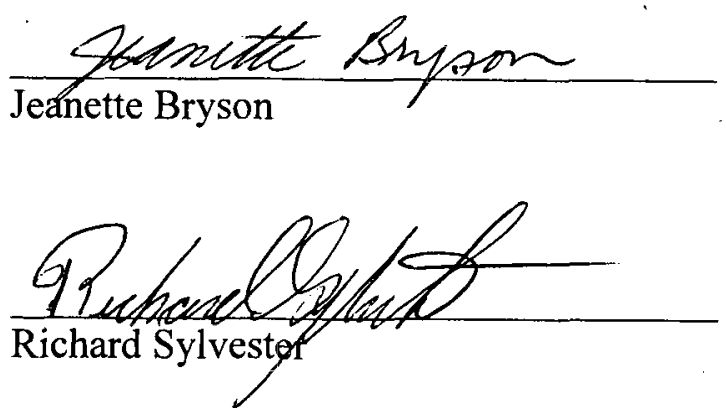

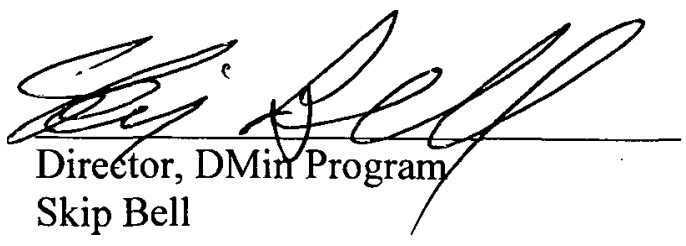

Denis Fortin.

Dean, SDA Theological Seminary Dennis Fortin

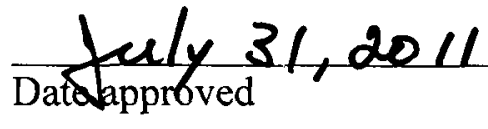




\section{DEDICATION}

To my wife Kalinda Shimunzhila a companion in Ministry, and to our children Mainza, Maangwe, Moonga, Mutobwe; my grand-children Nakaluwe, Nchimunya, and Edwin Jr. for their support. To my Lord and Savior, Jesus Christ, the source of wisdom. 


\section{TABLE OF CONTENTS}

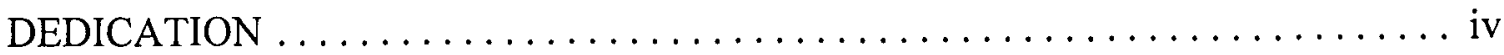

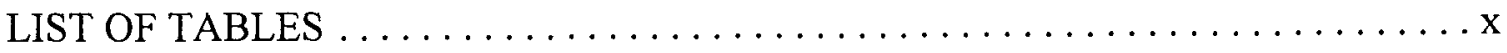

ACKNOWLEDGMENTS $\ldots \ldots \ldots \ldots \ldots \ldots \ldots \ldots \ldots \ldots \ldots \ldots \ldots \ldots \ldots$

Chapter

I. INTRODUCTION $\ldots \ldots \ldots \ldots \ldots \ldots \ldots \ldots \ldots \ldots \ldots \ldots \ldots \ldots \ldots \ldots \ldots \ldots$

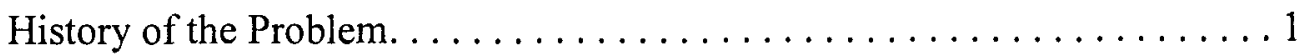

Purpose of the Project Dissertation ....................... 4

Statement of the Problem. ......................... 4

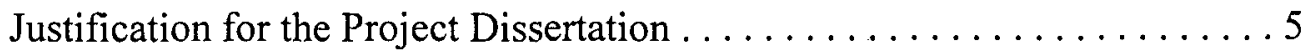

Expectations From This Project Dissertation $\ldots \ldots \ldots \ldots \ldots \ldots \ldots$

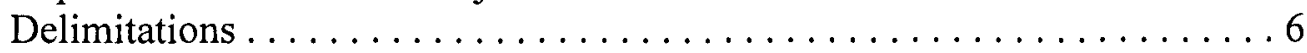

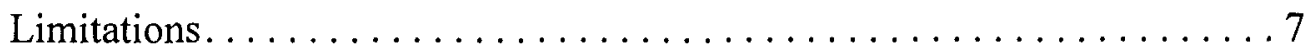

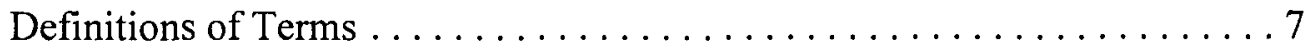

Methodology ................................. 10

Outline of the Dissertation. . . . . . . . . . . . . . . . . . 10

II. THEOLOGICAL REFLECTIONS ON INITIATING CHANGE $\ldots \ldots \ldots \ldots 14$

Initiating Change in the Old Testament. . . . . . . . . . . . . . . 14

Introduction .................................. 14

Joseph as a Change Agent ...................... 14

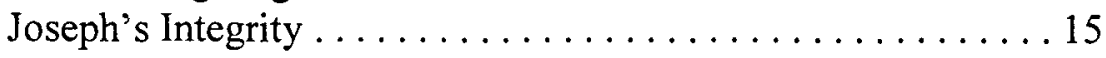

Joseph's Inclusiveness . . . . . . . . . . . . . . . 16

Moses as an Agent of Change ...................... 17

The Patience of Moses ...................... 17

The Inclusiveness of Moses . . . . . . . . . . . . . . . . 19

Moses as a Listener ........................ 20

Summary of Moses as a Leader . . . . . . . . . . . . . . . . 21

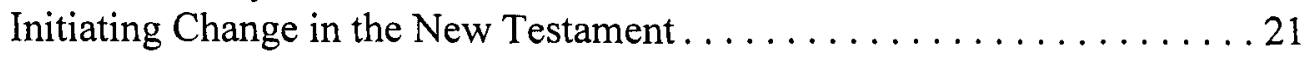

Jesus and Leadership Practices $\ldots \ldots \ldots \ldots \ldots \ldots \ldots \ldots . \ldots \ldots 22$

Acceptance (John 4:5-42) . . . . . . . . . . . . . . . 23

Discernment and Discretion..................24

Jesus and Conflict Resolution ..................25

Peter and Leadership to the Gentiles (Acts 10:1-48) ......... 27 


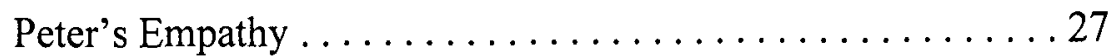

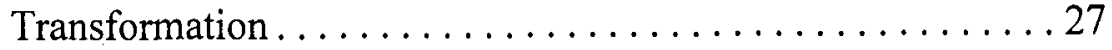

Cultural Sensitivity....................... 28

Mission Focus. . . . . . . . . . . . . . . . . . . . . . . . 29

Inclusiveness. . . . . . . . . . . . . . . . . . . 30

Cross-cultural Skills . . . . . . . . . . . . . . . . 31

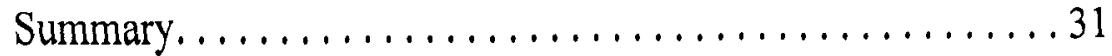

Paul as a Change Agent .......................... 32

Conflict Resolution. . . . . . . . . . . . . . . . . . . 32

Inclusiveness. . . . . . . . . . . . . . . . . . . . 33

Educator ................................... 34

Confidence .............................. 34

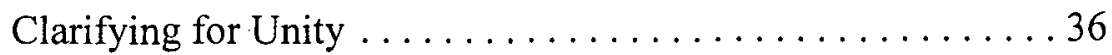

Summary.................................

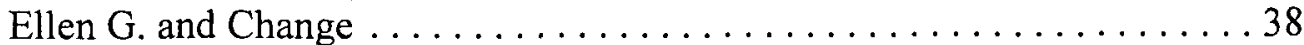

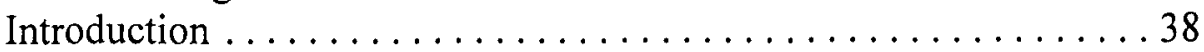

Counselor ............................... 38

Persistence and Determination..................... 40

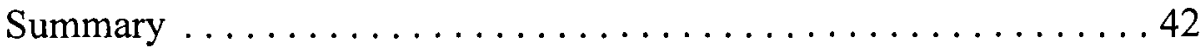

Conclusion ............................ 42

Elements of Initiating Successful Change $\ldots \ldots \ldots \ldots \ldots 42$

\section{LITERATURE CONTRIBUTING TO A SUCCESSFUL}

INITIATING OF CHANGE $\ldots \ldots \ldots \ldots \ldots \ldots \ldots \ldots \ldots \ldots \ldots \ldots$

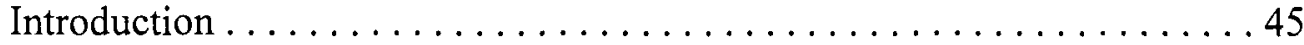

Literature on Initiating Organizational Change $\ldots \ldots \ldots \ldots \ldots \ldots \ldots 46$

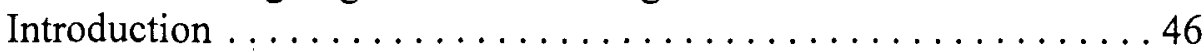

Definitions of Change ........................ 46

Nature of Change ...........................47

Change is Biblical....................... 47

Change is Dynamic and Inevitable................ 49

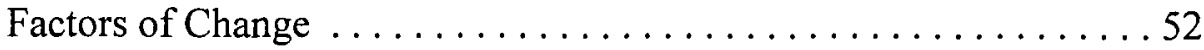

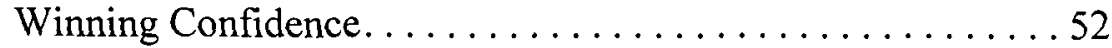

Behavior Change ........................... 53

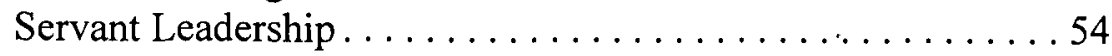

Strategies for Managing Change in the Organization ............ 55

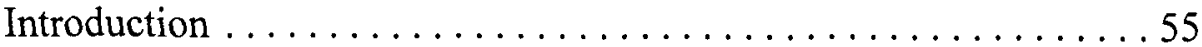

Initial Stages to Initiate Change $\ldots \ldots \ldots \ldots \ldots \ldots \ldots \ldots 6$

Strategies That Work .......................... 57

Strategy 1: Assess Church Situation............... 57

Strategy 2: Communicate Your Vision .............. 57

Strategy 3 : Be Inclusive .....................60 60

Strategy 4: Develop Other Skills ................ 61

Strategy 5: Understand Types of People . . . . . . . . . . . . . 64

Why is There Resistance to Change?..............66 
Handling Resistance to Change ..................69 69

Change and Culture ............................ 70

Culture is Learned $\ldots \ldots \ldots \ldots \ldots \ldots \ldots \ldots \ldots \ldots \ldots \ldots \ldots \ldots$

Cultural Differences........................... 72

Western, African Leadership Structure and Culture ........... 72

Western Leadership Structure and Culture. ........... 72

African Leadership Structure and Culture . . . . . . . . . . 73

Zambian Leadership Structure and Culture . . . . . . . . . . . . . 76

Household. . . . . . . . . . . . . . . . . . . . . . . 77

Village .............................. 77

Chiefdom ................................ 78

Impact of Culture in the Church. . . . . . . . . . . . . . . 78

Cultural Practices .............................79

Role of Local Leadership . . . . . . . . . . . . . . . . . . 8 81

Role of Women. . . . . . . . . . . . . . . . . . . . . . 81

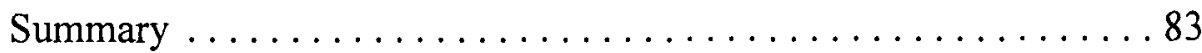

IV. ANALYSIS OF LEADERSHIP AND CHURCH GROWTH IN

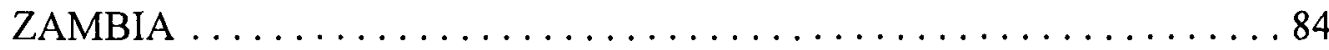

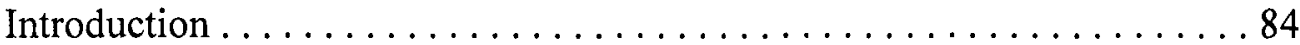

Contributions of Missionaries . . . . . . . . . . . . . . . . 84

Leadership Development. . . . . . . . . . . . . . . . . . . . 85

Summary .............................. 87

Profile of Zambia Union Conference at Initiating Change . . . . . . . . 88

Servant Leadership .......................... 90

Management and Marketing Strategies . . . . . . . . . . 91

Church Growth and Change in Zambia . . . . . . . . . . . . . . . 92

Structure Organization ......................992

Church Programs ...........................93

Church Statistics.......................93

Demographic Information of Pastors................. 95

Theological Background ..................... 95

Leadership and Management Training $\ldots \ldots \ldots \ldots \ldots \ldots \ldots . \ldots 96$

Statistics on Training $\ldots \ldots \ldots \ldots \ldots \ldots \ldots \ldots \ldots \ldots \ldots, \ldots \ldots \ldots$
Conclusion. $\ldots \ldots \ldots \ldots \ldots \ldots \ldots \ldots \ldots \ldots \ldots \ldots \ldots \ldots \ldots \ldots$

V. DEVELOPMENT OF INTERVENTION STRATEGIES FOR

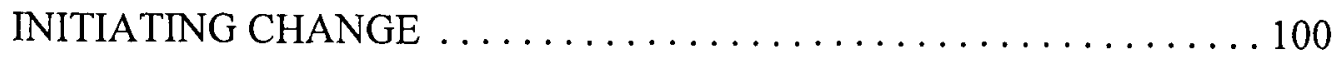

Introduction ............................... 100

Workshops for Pastors and Elders on Initiating Change.......... 100

Principles of Leadership and Initiating Change in OT. . . . . . . . 101

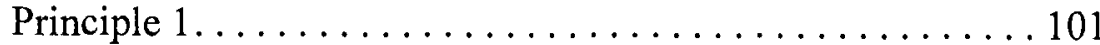

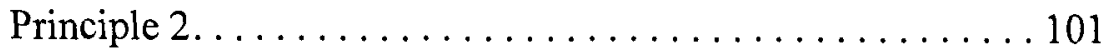

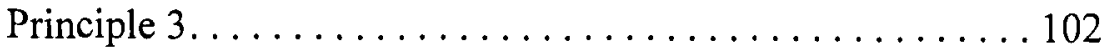




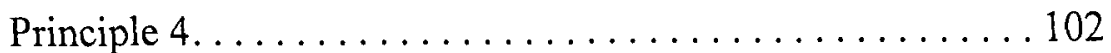

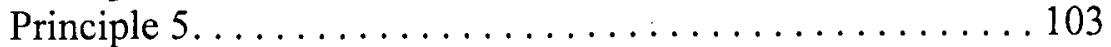

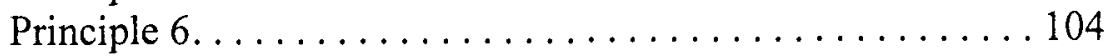

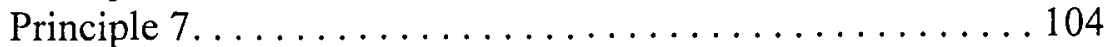

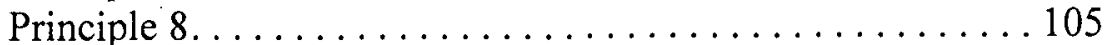

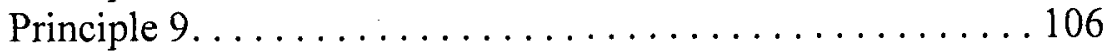

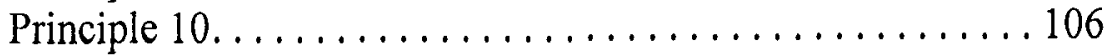

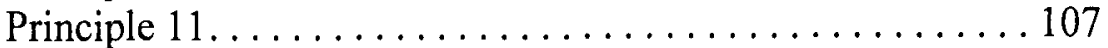

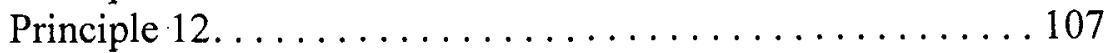

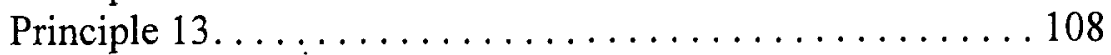

Principles of Leadership and Initiating Change in NT. ......... 109

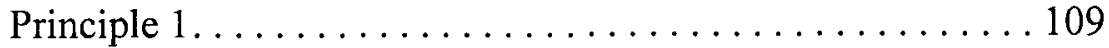

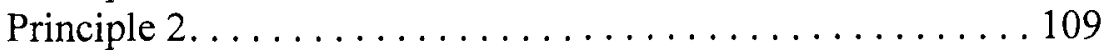

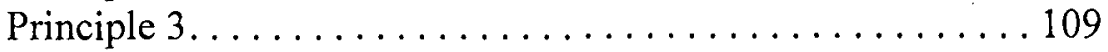

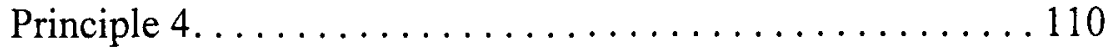

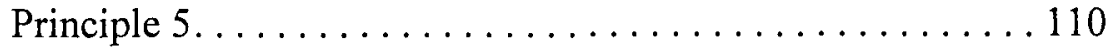

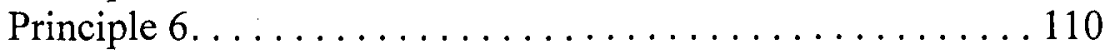

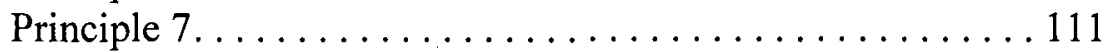

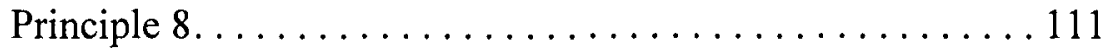

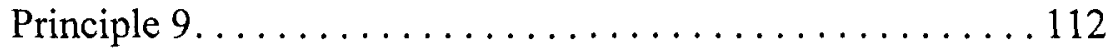

Spirit of Prophecy Counsel on Initiating Change $\ldots \ldots \ldots \ldots \ldots 112$

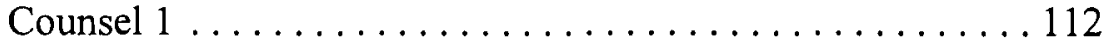

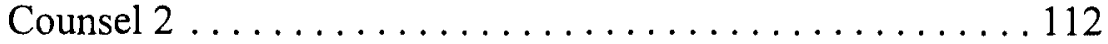

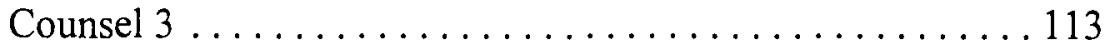

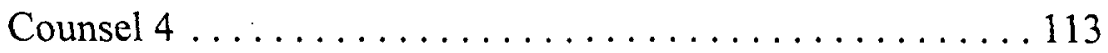

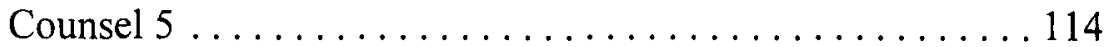

Spiritual and Cultural Steps Leading to Initiating Change ........... 114

The Spiritual Steps Leading to Initiating Change ........... 114

Step 1: Emphasize Spiritual Formation for the Leader ...... 114

Step 2: Develop Three Arenas of Movements in

Spiritual Formation.................... 116

Step 3: Develop the Breath of the Holy Spirit-Prayer . . . . . 117

The Cultural Steps Leading to Initiating Change. .......... 117

Step 1: Consider the Cultural Practices of Each Church ... . . 118

Step 2: Consider the Culture of the Community ......... 118

Step 3: Understand and Know the Elderly People in the

Church............................... 119

Step 4: Apply the Joseph Model................. 120

Teach Effective Methods for Initiating Change. . . . . . . . . . . 120

Method 1: Use Old Guard Method................. 120

Method 2: Use Adaptive Change Method ............ 121

Method 3: Use Marketing Method ............... 122

Method 4: Have an Inner-Circle. . . . . . . . . . . . . . . 122

Conclusion................................. 123 
VI. SUMMARY, CONCLUSION, AND RECOMMENDENTIONS. .

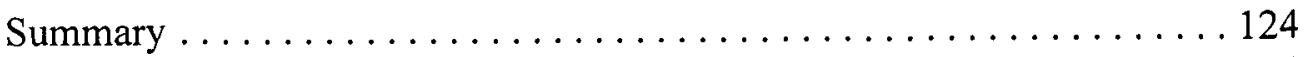

Essential Change Elements ...................... 124

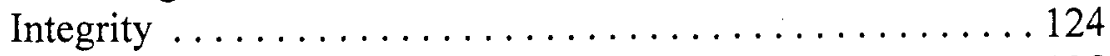

Leadership Credibility ....................... 125

Listening to the Members...................... 125

Clear Communication. . . . . . . . . . . . . . . . . 125

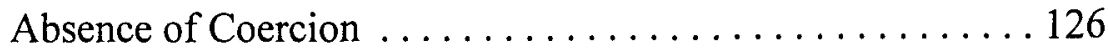

Inclusiveness of Process.................... 126

Cultural Sensitivity.......................... 127

Anticipation of Resistance . . . . . . . . . . . . . . . 127

Leadership Influence . . . . . . . . . . . . . . . . . 128

The Process of Change. . . . . . . . . . . . . . . . . . . . . . . 129

Adaptive Change ........................... 129

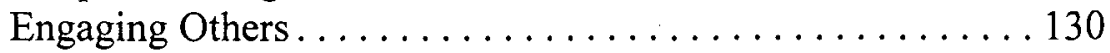

Demonstrating Change $\ldots \ldots \ldots \ldots \ldots \ldots \ldots \ldots \ldots \ldots \ldots \ldots$

Training for Change Competence .................... 131

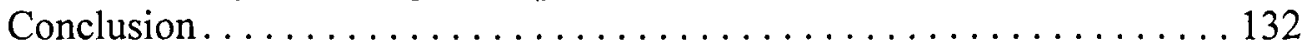

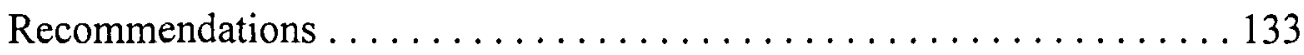

Zambia Union Conference. . . . . . . . . . . . . . . . . . . 133

Rusangu University ........................... 133

Local Conferences/Mission Fields. .................. 134

Local Churches. ........................... 134

Appendix

A. WORKERS MEETINGS IN LOCAL CONFERENCE/FIELD

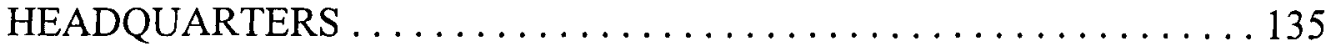

B. DAILY SEMINAR TIME TABLE. ................... 137

C. TOOLS TO BE USED DURING THE SEMINARS AND

WORKSHOPS....................................... 139

D. CREATING A STRONG VISION $\ldots \ldots \ldots \ldots \ldots \ldots \ldots \ldots \ldots \ldots \ldots \ldots$

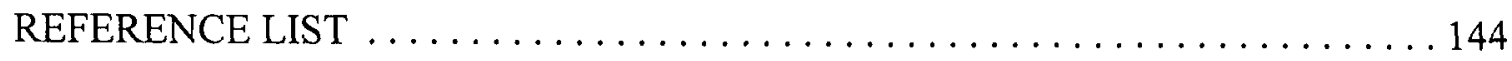

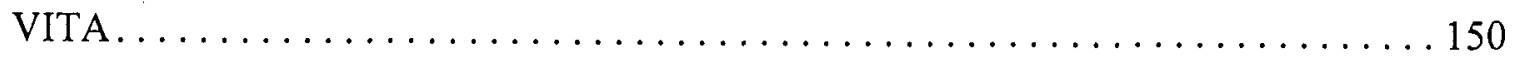




\section{LIST OF TABLES}

1. Zambia Union Conference Leadership Comparison Statistics............ 86

2. Zambia Union Conference Membership and Church Statistics ............ 94

3. Zambia Union Conference Pastoral Theological Background Statistics ........ 95

4. Pastors' Leadership and Management Trainings Conducted From 2005 to

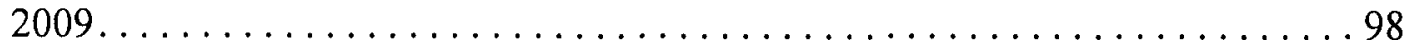




\section{ACKNOWLEDGMENTS}

My acknowledgement goes to my Almighty God who through the Holy Spirit inspired me to come up with and complete this project dissertation.

I am grateful to my beloved wife, Kalinda Shimunzhila, who is also a companion in the ministry, for her inspiration and encouragement in the completion of this dissertation. I am also grateful for my children Mainza, Maangwe, Moonga, Mutobwe and grandchildren Nakaluwe, Ncimunya and Edwin Jr. who have been supportive, encouraging and prayerful as I completed the dissertation.

I acknowledge the contributions of my advisers-Dr. Zebron Ncube, Professors Jeanette Bryson, Stanley E. Patterson and David Penno.

I acknowledge the encouragement of Mr. and Mrs. Stein Liyanda, Mr. and Mrs. Alfred Mudenda, Mr. and Mrs. Habadu Nchimunya, Mrs Hariet Chitalu, Mr. Harrison Muyeba, and Reeves Malambo for their moral and spiritual support to complete this dissertation.

I acknowledge the material and spiritual support from the Central Zambia Conference and the University Adventist Church in Lusaka. I also acknowledge all those members of the church that prayed and encouraged me to finish this dissertation. 


\section{CHAPTER I}

\section{INTRODUCTION}

Pue (2005) rightly states that change is good for the spiritual life of church members, and a leader must understand the times in which we live and respond to changes that come about in the community (pp. 210, 211). Paulsen (2009) adds that the world is not on "stand still;" thus, the life of the church "is dynamic" and it is in motion always (p. 13). Therefore, initiation of change is inevitable to every organization including the Zambia Seventh-day Adventist Church, regardless of Christian tradition and cultural heritage.

\section{History of the Problem}

The Seventh-day Adventist Church in Zambia holds on to cultural tradition such as traditional songs in preference to Advent Hymnals, and the Lord's Supper ceremony where women are to put on headgear before participating into it. Furthermore, new programs from the General Conference of the Seventh-day Adventist Church were introduced by church leaders and accepted though little resistance at times. These programs include (a) Junior Missionary Volunteers (JMV), (b) Adventist Youth (AY), and (c) Lay Activities to Personal Ministries. The method used by church leaders at the time involved educating the members. On the other hand, efforts by church leaders to 
initiate and effect change, especially the role of women in church worship, met with resistance from church members who want to maintain the cultural tradition.

Apart from holding to cultural tradition, the church wants to preserve its cultural heritage. Though the church in Zambia is multicultural, there is one common denominator: Patriarchalism. That is, the man is the head of the family and makes decisions. It has been said that Zambia has a strong culture due to the universal acceptance of the man as the head of the household.

Throughout its colonial and postcolonial history, Zambian women have always been treated with a little less respect than men. The cultural orientation of Zambia being male dominated and patriarchal, women were not given their due respect and position in society despite making significant contributions to it (Zambia Women, 2009).

Johnsson (2010) states that the 1990 Indianapolis fifty-fifth General Conference "delegates voted 1,173 to 377 that, because of the widespread lack of support in the world church at the time, the ordination of women to the gospel ministry would not be approved." He further states that at the 1995 General Conference Session in Utrecht, Netherlands, when the North American Division requested leeway to determine what would be best for the work in its territories," debate drifted to ordination of women and the motion lost massively, 1,481 no to 673 yes (pp.16-18). With this vote from the church in the business session, the church in Zambia remained strong in its stance on male leadership in line with its culture.

Johnsson (2010) states that the 2000 business session in Toronto, Canada, complicated the issue in Zambia when "a new Department of women's ministries was added" to the other departments of the world church (p. 18). This department was 
perceived by some pastors and lay leaders as a gateway to the ordination of women and would enable them to become church leaders. In addition, because of holding to their tradition in their understanding of 1 Cor 14:34, 35 and the strong Zambian culture that dictates that women are not to dominate over men in the church and community, the church leaders questioned as to how best to introduce this new department without conflict. The pastors and lay leaders faced the dilemma of having to respect the cultural tradition and culture of the country and, on the other hand, the decisions being made by the World Church.

Central Zambia Conference leaders were the first to introduce the new department of women's ministries. I was present when the introduction was done in Lusaka, the capital city of Zambia, at a large gathering of about 1,000 Dorcas workers and Adventist men's organization leaders and members. The way it was introduced was simple-to vote for or against the establishment of a department of women's ministries. After giving the background from the General Conference point of view, the vote was called. The delegates were Dorcas workers and members of the Adventist men's organization, and they unanimously voted against the new department of women's ministries. The rejection spread to other local conferences and mission fields in Zambia and parts of Malawi. Similarly, E. Mwale, East Zambia Field president (In personal communication, August $13,2010)$ said a large number of church elders gathered in the town of Chipata where leaders from the East Zambia Field office introduced the change, and there was no discussion allowed. The elders rejected the new department that led to the disbanding of ten organized churches in the East Zambia Field and one in Malawi. 
The department of women's ministries is just one example where pastors and lay leaders in Zambia find resistance to initiate and effect change in the church. The church leaders have tried to bring new programs according to current trends without conflicting with the Bible, Spirit of Prophecy, and the Church Manual. However, members still want to cling to the old programs and patterns. Very few churches have made significant changes to most programs, even after receiving instructions as to how and why the changes are to be made.

\section{Purpose of the Project Dissertation}

The purpose of this project dissertation is to develop a leadership model to successfully initiate and effect change in the Seventh-day Adventist Church in Zambia. Another objective is to develop strategies that will help pastors and lay leaders to a successful initiation of change.

\section{Statement of the Problem}

Pastoral and lay leadership in Zambia have not been successful in effecting change, especially in some programs that come from the Seventh-day Adventist Church Headquarters at the General Conference in Washington, DC. An example is the introduction of the department for women's ministries in the Zambia Union Conference, which many saw as a replacement of the cherished, vibrant, and active Dorcas Society, an organization involved in soul winning, nurturing, and community services. Attempts to introduce women's ministries met strong resistance and led to regrettable conflicts between clergy and laity, resulting in the disbanding of ten congregations in the East Zambia Mission Field alone. While a large portion of the membership resented the 
change, responsibility for the conflict seems to lie squarely on the church leadership due to the way the change was initiated from the very beginning. Such unnecessary conflicts that threaten the mission of the church will continue unless pastors and lay leaders follow a different leadership model in Zambia.

\section{Justification for the Project Dissertation}

The Seventh-day Adventist Church in Zambia is no exception to the changes that take place in the world and the General Conference of the Seventh-day Adventist Church. Church leadership in Zambia has not been successful in effecting change, especially some programs that come from the General Conference of the Seventh-day Adventist Church.

Presently, pastors and church elders experience unnecessary resistance from church members, whenever change is initiated. Conflicts slow down and derail the mission of the church in Zambia. The case in point is the East Zambia Field, where 10 churches were disbanded because of the introduction of the department of women's ministries. While the churches in Zambia rejected the change, it seems that only East Zambia Field churches were disbanded, perhaps because they were said to be rebellious. The pastors in Zambia, especially in the East Zambia Field, spend much time in resolving internal issues rather than doing evangelism and soul winning among those who have not heard the message.

The Zambian culture also continues to be a challenge to church leadership, especially when change is initiated. It is perceived that changes that come from the General Conference of the Seventh-day Adventist Church are Western and not African. 
This project dissertation will help the church leaders in Zambia reduce tensions that are going on in some churches where women are not allowed to preach from the pulpit during the divine service on Sabbath. Therefore, time devoted to this project is worthwhile, for the sake of unity, education, and spirituality in the Zambia Union Conference of the Seventh-day Adventist Church.

\section{Expectations From This Project Dissertation}

This project dissertation will help advance the spread of the gospel in the Zambia Union Conference of the Seventh-day Adventist Church. It will transform the dynamics of church leadership among pastors and elders by providing them with necessary tools. It will provide a stage for adapting to modern church leadership skills rather than resorting to old ones that no longer meet the test of time. It will provide techniques to better manage challenges during transitions and when initiating change by providing proper education to pastors and lay leaders. It will help pastors learn how to facilitate a teambased approach to leadership skills by working in unity with lay leaders. It will help develop interactive skills for leaders and members by good communication. Finally, it will enhance curriculum development for the Rusangu University that is focused on preparing pastors for leadership and management.

\section{Delimitations}

This project dissertation was delimited to the Zambian Union Conference in the Southern Africa-Indian Ocean Division (SAID) of the Seventh-day Adventist Church. This included all the pastors and lay-leaders in the Zambia Union Conference. 


\section{Limitations}

The major limitation of this dissertation was that it was not field-based but was an intensive program. The time was limited to be in the field to interview a number of pastors and lay leaders and collect the actual data. Only a few individuals were interviewed to give a sample analysis of the situation on initiating change and these were by appointment. There was no questionnaire sent out to individuals to get relevant information for the study.

Furthermore, this dissertation was limited to church leaders who in most cases initiate change. The dissertation was also limited to asking and answering the following questions: Why initiate change? Where to initiate change? When to initiate change? How to initiate change?

\section{Definitions of Terms}

Adaptive Change: Heifetz, Grashow, \& Linsky (2009) state that leadership engages people to make a difference to that which must be preserved and that which must be changed according to the situation (p. 15).

Adaptive Leadership: Heifetz et al. (2009) state this kind of leadership helps leaders to strive toward adapting to "new environment, and to new dreams" that need mobilization of "new strategies" (p. 14).

Conference: In this project dissertation, it refers to a self-supporting suborganization or unit of the Zambia Union Conference. Zambia Union Conference is made up of two conferences (Central and Southern) and five none self-supporting Mission Fields (Copperbelt, Northern, Luapula, Wetern, and Eastern). Sometimes it is called a local conference and is made up of a number of churches and companies. It serves an 
administrative role for pastors and local churches. The delegates from local churches appoint the officers of the conference at duly called sessions.

Change: Macionis (2007), from a sociological perspective, defines change to mean "the transformation of culture and social institutions over time" (p. 483). The operational fields of change, according to Holberton (2001) are: "strategy, structure, people, systems, culture," and much more (p. 13).

Culture: Northouse (2007) states that culture is a way people live in the community and it includes their beliefs, values, rules, norms, symbols, and traditions (p. 303).

Division: This is a sub-organization of the General Conference composed of Union Conferences and Union Missions.

General Conference: This is the highest administrative body of the Seventh-day Adventist Church. Now, it is composed of thirteen Divisions. At its General Conference session, it makes recommendations to be adopted by the churches around the world.

Lay Leader: In this dissertation, a lay leader is one elected to serve a congregation on voluntary basis and assists and gets directives from the pastor of the church.

Leader: Leader is one that is empowered by the Holy Spirit and is credible and capable to influence others to follow God's direction.

Leadership: According to Bell (2003) leadership does not refer to a particular position, administration, and statesmanship but to the practices of God-driven pastors and members as they use their spiritual gifts for the church to be effective in its mission (pp. 5-11). 
Mission Field: An area considered a sub-organization or unit because it is financially dependent. In this case, a mission receives financial assistance from the Union Conference.

Multicultural Congregation: This refers to a local church composed of different ethnic groups of people with different cultural backgrounds. There is no cultural group that dominates the other.

Pastor: In this dissertation, the pastor is a full-time minister or worker employed by the church organization. The person may or may not be ordained to the ministry. They may also be in charge of a congregation or district in all its activities. He or she may serve as a departmental director or administrator of a conference.

Status Quo: Ridley and Goodwin (2003) state that people are comfortable in their usual environment and are naturally inclined to resist any change that may come (p. 19). In this project dissertation, people want to maintain the usual way of doing things without giving consideration to change.

Union Conference: This is an economically independent and administrative unit of the division. Delegates from the local conferences and mission fields appoint the officers and departmental leaders.

Missionary: Mish (2003) states that this is a person sent out for a religious mission by an organization (p. 795).

Southern Africa-Indian Ocean Division: This is a sub-organization of the General Conference of the Seventh-day Adventist Church. 


\section{Methodology}

The research method I chose to use in this dissertation is theoretical: Extracting information from what other scholars have written on change and the change process will be presented in the Zambian context. This method considers current and relevant information from books, articles, journals, on-line data, newspapers, and available data from the Zambia Union Conference. The process will include the following:

1. A theological reflection on initiating change. This reflection will center on four biblical themes which include (a) the Joseph and Moses methods of initiating change, (b) the Servant Leadership of Jesus, which changed the lives of people, (c) Jesus, Peter, and Paul initiating change across racial barriers, and (d) initiating change as it is seen in the writings of Ellen G. White.

2. A current review of literature contributing to a successful initiation of change. This will include:

1. Anthropological literature on Zambian culture, which will help pastors and elders when initiating change.

2. An analysis of leadership and church growth in Zambia.

3. The development of intervention tools and strategies for initiating change.

As a result of this project dissertation, it is hoped that future seminars and workshops for pastors and lay leaders will be conducted in all conferences. Materials on strategies for initiating change for pastors and lay leaders will be developed.

\section{Outline of the Dissertation}

This dissertation is divided into six chapters. Chapter I: "Introduction" introduced giving an overview of the dissertation. It began with the history of the problem to be 
studied, purpose of the dissertation, statement of the problem, justification for the problem, and expectations from this project. Furthermore, it included delimitations, limitations, some definition of terms used, and methodology.

Chapter II: "Theological Reflection on Initiating Change" is divided into the following three major sections apart from the introduction and summary:

1. The first is the theological reflection on Old Testament leaders, Joseph in Egypt, Moses in Egypt and leading the Israelites to the Promised Land of Canaan, and finally Jethro when he met Moses in wilderness.

2. The second section presents leaders in the New Testament with (a) Jesus responding to the Samaritan Woman, and (b) Peter and Paul working with Gentile converts.

3. The third section focuses on initiating change as it is presented in the writings of Ellen G. White.

Chapter III: "Contributing to a Successful Initiation of Change" is divided into the following three major sections:

1. The first section focuses on literature having to do with organizational change, answering such questions as: Why initiate change? Where to change? What to change? When to change?

2. The second section presents strategies for managing organizational change. In this section, the question is: How to initiate change?

3. The third section deals with change as it relates to culture. This section is based on literature from and about Zambia in reference to the practice of leadership in the 
family and church. Also included is a review of literature about the Western culture as it relates to Zambian culture and change.

Chapter IV: "Analysis of Leadership and Church Growth in Zambia" is divided into two sections. The first section is leadership and includes (a) an introduction hat discusses the effects of colonialism, (b) contribution of missionaries, and (c) leadership development. The analysis considers two issues:

1. Holding to church and community traditions.

2. The manner in which women's ministries was introduced in Zambia Union Conference.

The section also discusses servant leadership, management and marketing strategies, adaptive change and structure organization. The second section of the chapter discusses (a) theological background of pastors, and (b) leadership training.

Chapter V: "Development of Intervention Strategies for Initiating Change." The chapter is divided into the following three sections:

1. The first section describes the workshops for pastors and elders on initiating change. This section focuses on workshops that present the principles of leadership and change that was initiated and recorded in the Old and New Testaments. It concludes with counsel from the Spirit of Prophecy on initiating change.

2. The second section presents workshops on spiritual and cultural steps leading to initiating change.

3. The third section instructs the reader how to use effective teaching methods to effectively initiate change. 
Chapter VI: "Summary, Conclusions and Recommendations" is divided into two sections:

1. The first section is a summary of information gleaned from theological reflections and literature that point out the essential steps to effectively initiating sustainable change.

2. The second section shares recommendations drawn from chapter conclusions. 


\title{
CHAPTER II
}

\section{THEOLOGICAL REFLECTIONS ON INITIATING CHANGE}

\section{Initiating Change in the Old Testament}

\author{
Introduction
}

Both the Old and the New Testaments have many examples of leaders who tried to initiate change. For the purpose of this study, I selected Joseph and Moses in the Old Testament to develop a model for initiating change in the Seventh-day Adventist Church in Zambia. The discussion continues in the New Testament with Jesus, Peter, and Paul as leaders who initiated change. In addition, Ellen G. White is included because she played an authoritative role and provided leadership in the Seventh-day Adventist Church, and she initiated change in the church.

\section{Joseph as a Change Agent}

To begin the introduction to the qualities that characterize biblical leaders and the effect these traits have on change, let's look at Joseph. Israel was a nation under a theocracy from small beginnings in Abraham, Isaac, and Jacob. It was during the time of Joseph that Israel grew numerically strong when in Egypt. Jacob and his family settled in Egypt and, due to Joseph's position of power, they were given the land in Goshen. Joseph was a change-agent whom God used to fulfill the covenant He made with Abraham and 
reiterated to Isaac and Jacob. Among many strong qualities that Joseph had, ones that seem to stand out in his leadership role are integrity and inclusiveness.

\section{Joseph's Integrity}

In this section, I am going to discuss integrity as a leadership model based on the life of Joseph. Haynes (1962) states that Joseph was Jacob's favorite son because he "had a natural sweetness of disposition" and lovely character (p. 28). White (1958) describes Joseph's character from childhood as "pure, active, and joyous" and she adds that he was of "moral earnestness and firmness" (p. 209). As a youth, he dedicated his whole life to godliness and that made him grow as a noble youth of integrity and trust.

Therefore, integrity in Joseph as a leader did not just happen later on in his life. It is something that he acquired very early in his life, and it showed up in various situations that Joseph found himself, such as (a) his brother's bad behavior, (b) the allurement of Potiphar's wife, and (c) the confrontation with his brothers.

His brother's behavior prompted him to bring "a bad report of them to his father" (Gen 37:2). Why did he report them to their father? On one hand, White (1958) states that "the evil conduct of his brothers troubled him greatly" (p. 209) and that is why he reported them. Furthermore, Nichol $(1978,1: 428)$ adds that Joseph was afraid that his brothers' evil deeds might dishonor the family name in the community. Haynes (1962) states, "he was jealous for the family" and could not conceal their evil deeds, so Joseph reports to Jacob to protect the family name (p. 29). The Bible states that because he reported them to their father, they hated him more (Gen 37:4).

Later Joseph served as a slave in Egypt in the house of Potiphar, and the Lord was with him (Gen 39:1-3). White (1958) adds in relation to Gen 39:3-6 that, from childhood, 
Joseph expressed and developed qualities of leadership in his daily life in Egypt, such as gentleness, fidelity, and truthfulness (p. 209). Even though he lived an upright life, he was allured to commit adultery with the master's wife (Gen 39:6-18). Joseph

(a) maintained his pure character, (b) did not succumb to sin, and (c) ran away (Gen 39:8-9, 12). Northouse (2007) states that Joseph maintained his integrity, "the quality of honesty and trustworthiness" (p. 20).

A spirit of forgiveness also proves Joseph's integrity. The very people that sold him as a slave, when he ascended to a position of leadership in Egypt, he forgave. He did not retaliate against their evil deeds. A person of integrity has the capacity to stand for what is right when everybody else does wrong. A person of integrity does not give in when under pressure to compromise principles or values. A person of integrity extends unconditional forgiveness to those who would do harm or when subjected to criticism. Moran, Harris, and Moran (2007) concludes that "trust and confidence are essential elements needed for successful" change in the church by leaders (p. 615).

\section{Joseph's Inclusiveness}

After Joseph presents the meaning of the dreams, Pharaoh wants to discuss possible solutions. Joseph engages Pharaoh and the entire cabinet in the process (Gen 41:33-38. White (1958) states, "For some time the matter of the appointment was under consideration" (p. 221). Nichol (1978, 1:447) adds that after discussions with his cabinet "the king proposed the appointment of Joseph as minister of food, and granted him emergency powers." Joseph accepted the responsibility and executed the strategies needed for survival during the drought to come (Gen 41:39-49). Joseph organized the 
construction of silos for storage and created a long-range "national plan of food administration and general welfare for the famine years" (Haynes, 1962, p. 114).

Because Joseph involved others in the process of decision making, it was easy for him to get support for the massive project. He made sure that those affected by the decision were included in the discussion.

\section{Moses as an Agent of Change}

Moses went through difficulties in dealing with the Israelites from Egypt through to the wilderness. He became God's agent to liberate the Israelites from bondage in Egypt and lead them to the Promised Land of Canaan. He taught him how to lead and develop effective leadership qualities. He became an agent of change for the Israelites.

His leadership began in Egypt, when he tried to liberate the Israelites through force by killing an Egyptian who was fighting a Hebrew. This was not the plan of God. Hence, circumstances forced him to flee to Midian, where he stayed for forty years. This was a leadership training session for him.

In this section, I am looking at three qualities of leadership that stand out in the life of Moses: (a) patience, (b) inclusiveness, and (c) listening.

\section{The Patience of Moses}

Moses grew up in the palace. As a grown man, he went to see his own people and saw how they were suffering from the leadership of Pharaoh (Exod 2:11). He chose to suffer with his own people rather than live in the palace as an adopted son to Pharaoh's daughter (Heb 11:24-26). White (1958) observes that Moses was troubled in his mind and thought of how to free Israel from slavery. He visited them in their places of labor and 
assured them that God would soon deliver them from injustice and oppression (p. 246). One day when he saw an Egyptian beating a Hebrew, he was greatly troubled in his mind and ended up killing the Egyptian (Exod 2:12). At this stage, Moses was impatient; hence, he took the matter into his own hands.

White (1958) states that to him, the military training he got was enough to liberate the children of Israel from slavery through military force (p. 247). By killing an Egyptian whom he found beating a Hebrew (Exod 2:12), Moses felt he was ready enough to mobilize the children of Israel to rise against slave masters. He tried to pressure his influence to the Israelites and convince them that God was using him for deliverance, but his efforts did not yield any good result (Acts 7:25). White adds that the use of force was not God's plan (p. 247). Moses fled to Midian and stayed there for forty years (Exod 2:15). In this wilderness setting, he learned to control his emotions.

In Midian, while Moses was tending the flock of his father-in-law Jethro in the desert area and near mount Horeb, he encountered the presence of God in a flame of fire in a bush (Exod 3:1-3). It was at this time that God called him to be his agent of deliverance for the children of Israel (Exod 3:10). During the forty years in Midian, looking after the flock of Jethro, Moses learned patience.

During the plagues, Moses exercised patience as he visited Pharaoh several times (Exod 7:8 - 11:2). In all visits, Pharaoh did not let the Children of Israel go out of Egypt; instead, God hardened his heart. Moses was not upset but continued visiting and talking to Pharaoh with his brother Aaron. After the Midian experience, Moses exhibited patience and unhurriedness to bring meaningful and successful change--a quality required of a leader. 
The Red Sea experience is another situation where Moses exercised patience. The children of Israel crossed the Red Sea and traveled through the wilderness with God as their guide, leading by flame at night and a cloud by day. As the Israelites were in the midst of crossing the Red Sea, the Egyptian army pursued them (Exod 14:9-22). Maxwell (2007) commenting on these verses states that Moses was under pressure from his people on how to handle the various crises. Moses was at peace with God and himself. His confidence in God gave him the ability to remain calm through complaints and challenges (p. 84).

After the crossing of the Red Sea, the Israelites had a shortage of water in the wilderness. When they came to Marah, they found water, but it was bitter; they could not drink it. They again complained against Moses, and he talked to God. God heard their complaint. God gave instructions to Moses, and through a miracle, the bitter water was pure (Exod 15:23-25). In this incidence, Moses exercised patience, for he did not rebuke them when they complained. Moreover, when complaints came to Moses, one after another over various issues, whether the need was food or conflict resolution, Moses would turn to God and allow him to lead (Exod 16:3-13).

\section{The Inclusiveness of Moses}

After the forty years in Midian, Moses went back to Egypt because those who had sought to kill him were dead (Exod 4:19). In the meantime, God assigned Aaron to go and meet Moses as recorded in Exod 4:27. Moses tells Aaron all that the Lord has said. Moses begins to show his inclusiveness in that the two brothers meet with the elders and then the people prior to proceeding (Exod 4:28-31). 
After meeting with the elders and the general assembly of the people, Moses, as an agent of change for God, went with his brother Aaron to meet Pharaoh and ask him to let the Israelites go to worship their God in the wilderness (Exod 5:1). Pharaoh hardened his heart and did not let the people go (Exod 5:2). The first nine plagues poured upon the Egyptians, but Pharaoh did not let the people go (Exod 7-10). Pharoah would not release the people until the tenth plague and the death of the first-born sons (Exod 12:29-32). Thus, the exodus of the Israelites started as recorded in Exod 13:20-22.

The inclusiveness of Moses is seen (a) first in his willingness to assign a major role to someone other than himself, (b) his willingness to counsel with the elders, and (c) then in the "mixed multitude" that traveled with him throughout Egypt.

\section{Moses as a Listener}

As Moses and the Israelites travel away from Egypt, his family joins him. Jethro, his father-in-law, observes Moses' leadership style and suggests the following:

You shall select from all the people able men, such as fear God, men of truth, hating covetousness; and place such over them to be rulers of thousands, rulers of hundreds, rulers of fifties, and rulers of tens. In addition, let them judge the people at all times. Then it will be that every great matter they shall bring to you, but every smaller matter they themselves shall judge. Therefore, it will be easier for you, for they will bear the burden with you. (Exod 18:21, 22)

It seems that Jethro knew that Moses had been trained to work in a hierarchal system, with the pharaoh of Egypt serving as the sole leader. He also had observed that Moses was a good listener and learner when taught how to care for the sheep; so, he made these suggestions for a shared leadership. Moses not only listened, but he put into practice what he was told. It was as if Jethro had assessed the situation and then organized a short workshop on leadership for Moses. 
White (1958) states a change of leadership style may result in "establishing more perfect order" (p. 301). When reading the account found in Deut 1:13-15 it suggests that at first Moses assumed all the leadership roles of the Israelites because that is how surrounding nations practiced as a cultural issue. Moses at this time heeded the counsel from Jethro and included other leaders in his administration (Exod 18:24-26). This was a new method of separation of duties because Moses could not handle the bulk of issues brought to him by the Israelites alone.

Moses adopts a collaborative approach by involving others in decision making (Exod 18:25-26). After meeting his father-in-law in the wilderness (Exod 18:13-23), Moses' method of leadership changes immediately from micro-managing to empowering chosen leaders from the congregation (Exod.18:24-27). His role now is that of judge and counselor.

\section{Summary of Moses as a Leader}

Moses begins his connection with the Israelites from the context of the Pharaoh's training. His natural tendency toward autocratic leadership, coupled with his impatience, proves disastrous. He learns patience and the ability to listen as he herds sheep in Midian. Later, these qualities serve him well as the leader of Israel.

\section{Initiating Change in the New Testament}

In the New Testament, there are insights into the qualities that characterize leaders who were change agents, either in the spiritual lives of individuals or in the culture of the people as they receive the gospel. The leadership models, including the 
servant leadership model of Jesus, Peter, and Paul, highlight some elements of initiating successful change in the cultural context.

Jesus introduces servant leadership by His lifestyle. He is willing to be interrupted and willing to help. The various aspects of servant leadership are addressed in John 8:1-59. Maxwell (2007) compares the secular leadership model to that of servant leadership model (p. 1316).

The secular leadership model indicates that the leader gains influence through leverage power. The leader possesses confidence through competition and success. The leader acquires authority through claiming rights and position. The leader grows an organization through demand of people. Whereas, the servant leadership model suggests that the leader gains influence by loving people (Phil 2:3-11). The leader possesses confidence by depending on God (2 Cor 3:4-6). The leader acquires authority through servanthood (Matt 20:20-28). The leader grows an organization through developing people (Acts 19:8-10).

\section{Jesus and Leadership Practices}

In most cases, it seems that Jesus appeared to lose the battle for change. It is not surprising to see pastors and lay leaders in Zambia not succeeding in initiating change. In this section, I am going to discuss some practices that appeared to have hindered change. These practices are exhibited in the interaction between Jesus and the Samaritan Woman, and Jesus' healing on the Sabbath. 


\section{Acceptance (John 4:5-42)}

Jesus reached across cultural boundaries. The meeting with the Samaritan woman is a good example of how Jesus handled the cultural issue. Jesus and his disciples crossed over to the other side of the country, but they had to pass through Samaria. Samaria was a Gentile country, which had no common dealings with the Jewish nation. As they were passing through Samaria, they got tired and thirsty; so, when they came to Jacobs' well, they hoped to get drinking water. Jesus sent his disciples into town to buy food while $\mathrm{He}$ remained at the well. A Samaritan woman came to draw water and found Jesus at the well. When Jesus asked the woman for drinking water it was shocking because Samaritans and Jews did not share the same spaces. Bypassing cultural guidelines, a dialogue takes place that leads the Samaritan woman to an understanding of salvation, and that consequentially leads to the conversion of many men from the town.

White (1940) states that culture held that "the Jews and the Samaritans were bitter enemies," and they had nothing in common with each other. Jews regarded Samaritans as an impure race; in other words they were unclean (p. 183). Jesus had been aware of this cultural difference between Jews and Samaritans when He sat at the well to wait for someone to offer Him a drink of water.

The question the Samaritan woman asks Jesus, "How is it You, being a Jew, ask a drink from, a Samaritan woman?" (v. 9) and the silence of the disciples (v. 27) points to a problem dealt with immediately. Jesus here encountered a cultural issue while demonstrating acceptance.

Heifetz et al. (2009) suggest that it is better first to (a) assess the situation, (b) take the best of the tradition, people identity and the history of the people, and (c) incorporate 
them into the change situation (pp. 22, 23). In addition, they add that the leader should "connect with the values, beliefs, and anxieties of the people you are trying to move" for change (p. 38). Jesus, being culturally sensitive, cut short the cultural problem that existed in preference to a spiritual change in the life of this woman (John 4:9, 10).

\section{Discernment and Discretion}

Communication involves both speaking and listening. Jesus' conversation with the Samaritan woman demonstrates His acceptance of her cultural background because He carries on a conversation with her. He is exhibiting the quality of listening. Jesus took time to listen to the woman at the well. He understood the art of carrying on a conversation. He listened and redirected the cultural topic to that of a spiritual nature (John 4:10). One of the reasons for the success of this maneuver was His willingness to take time to listen (White, 1940, p. 188). It is important for leaders initiating change to have a listening ear that allows others to speak.

After allowing the woman to speak, Jesus responded by saying that "the hour is coming" (John 4:21). It was now His opportunity to educate the woman to differentiate the spiritual from cultural matters. White (1940) adds that, at this time, He aimed at lifting her thoughts "above matters of form and ceremony, and questions of controversy" (p. 189). As indicated in the Scripture (John 4:7-26), Jesus did not dominate the discussion; instead, He included the woman and even encouraged her to take part. This is exemplified in the flow of the conversation:

1. He starts by asking for water to drink (v. 7).

2. The woman responds in a cultural manner (v. 9).

3. Instead, Jesus responds in a spiritual manner (v. 10). 
4. The woman responds by seeking for clarity regarding physical and spiritual water (vv. 11, 12).

5. Jesus continues emphasizing on spiritual rather than physical matter; He speaks of the "living water" (vv. 13, 14).

6. The woman asks for the living water (v. 15).

7. Jesus changes the subject to make a point regarding social issues (vv. 16-18).

8. The discussion changes from spiritual, social, and now back to cultural issues as in verse 9 (vv. 19-22).

9. Finally, the purpose of the conversation is revealed as she acknowledges Him as the Messiah (vv. 23-26).

In the final analysis, because of clear communication, White (1940) observed that Jesus brought dramatic change, not only to the woman but also in the lives of many Jews and Samaritans. He had broken the cultural line of partition between the two peoples. It was after the experience with the Samaritan woman that the Jews and Gentiles mingled together (p. 193).

\section{Jesus and Conflict Resolution}

In the time of Christ, the Talmudic beliefs of the Jewish nation had taken preference over the biblical laws. Jesus knows the intent of the law. Jesus confronts opposition from the Pharisees, Scribes, and other Jewish leaders (John 8:1-59). In John 5:2, a narrative begins that shows how Jesus chose to bring new life and beliefs to the Jews, bring freedom to the people from the hardships and confront Jewish legalism. Jewish legalism had hindered needed change in the lives of many common people. 
The Jews felt that Jesus was creating conflict because of His healing of the sick on Sabbath. They rejected the ministry of Jesus because He broke their tradition of not caring for the sick on Sabbath. On this particular day, Jesus demonstrated to the Jewish leaders that the Sabbath was not to be a burden. However, healing on the Sabbath day, and instructing the healed man to take up his bed, broke the Sabbath legislation according to the Jewish tradition.

Jesus, through this act of healing on the Sabbath day, demonstrated that He was destroying the tradition that hindered many to accept Him as the Messiah. He had a direct conflict; most of the people would have missed the lesson. By simply healing this man, Jesus avoided direct conflict. He earned His credibility from the results and not from rhetoric.

On other occasions, Jesus engaged the Jewish leaders in conversation. At times, He was a model of diplomacy as He addressed issues; at other times, He confronted the Scribes and Pharisees. John 8:1-59 presents His confrontation with the Pharisees, Scribes, and other Jewish leaders.

Jesus is our model in dealing with conflicts that derail change in the church. From His example I learned that a leader must be a good communicator (John 5:48, 49). The leader must be clear and direct to the issue at hand. The leader should not cultivate the spirit of selfishness (John 5:49, 50). The leader should not draw undue attention to himself or herself. The leader should invite members to participate in the change process (John 5:51). More importantly, the leader must act as well as lay out the issue and ask for decisions. Finally, the leader should trust in the Lord (John 5:52-54). 
Peter and Leadership to the Gentiles (Acts 10:1-48)

Peter accepted the invitation to be God's agent of the gospel to the Gentiles, starting in the home of Cornelius. While in the home of Cornelius, Peter exemplified some leadership qualities to the people who gathered to hear him speak the Word of God. These qualities included empathy, transformation, cultural sensitivity, mission-focused, and inclusiveness. This section, however, will address the quality of empathy.

\section{Peter's Empathy}

In the course of his ministry, Peter and other disciples visited some congregations in Lydia and Joppa. While doing some visitations to believers in Lydia, he received a message that one of the believers by the name of Dorcas had died. Peter went to Joppa, and upon arriving at the funeral house, he found widows weeping. Peter felt compassion for the mourners, prayed unto God to restore her life, and Dorcas was brought to life again.

\section{Transformation}

Before Peter could take the gospel to the Gentiles, Peter had to examine himself. He had to have prejudice removed from his mind; it required boldness and courage to allow his strong cultural beliefs to be transformed. Peter had to choose to obey and trust in God; then, transformation took place.

A willingness to be taught is one of the critical qualities of a leader. In this case, God needed Peter to learn that the Gentiles were all precious in God's sight. He was teachable and experienced a total transformation in his life and ministry (White, 1911, p. 136). 


\section{Cultural Sensitivity}

In the first instance, for Peter to attend to Cornelius' call to visit in his home took a willingness to be culturally sensitive. To be in the home of a Gentile was an unacceptable gesture to the Jewish nation. White (1911) observed that in the minds of the apostles, including Peter, "the middle wall of partition, broken down by the death of Christ, still existed, and their labors had been confined to the Jews, as they looked upon the Gentiles as excluded from the blessings of the gospel" (p. 136).

Nevertheless, he went to Cornelius' home. He arouses the interest of the hearers in the house of Cornelius by talking about the cultural barrier between Jews and Gentiles. The Jews and Gentiles, according to their culture, could not mingle together (Acts 10:28). Heifetz et al. (2009) suggest that it is better to first assess the situation, take the best of the tradition, acknowledge people's identity, and their history, and then incorporate them into the change situation (pp. 22, 23).

White (1911) states that when Peter arrived at Cornelius' home, he spoke first of the custom of the Jews and Gentiles that prevailed at that time, before preaching Christ's life, ministry, betrayal, resurrection and ascension (p. 138). This order of presentation shows Peter's willingness to approach the subject with respect for the people. He then self-actualized, sharing his experience with the vision (Acts 10:27-29). This approach opened the way for Cornelius to share in the conversation. Cornelius explained how $\mathrm{He}$ fasted and saw an angel of the Lord with a message for him (Acts 10:30-33). Together, the sharing led to Peter's sermon culminating in the coming of the Holy Spirit (Acts 10:34-46). 


\section{Mission Focus}

Though the discussion in the first place dominated on clarity on tradition and culture of the Gentiles and Jews, Peter focused on his mission to preach the gospel. He did not dwell much on the issue of culture, but instead dwelt on the gospel. Peter said, "In truth I perceive that God shows no partiality. But in every nation whoever fears Him and works righteousness is accepted by Him" (Acts 10:34, 35). The saying is an indication of Peters' mission to the people who gathered in the house. He shows that they are also part of the gospel and that he accepts all people regardless of culture differences.

White (1911) states Peter continued preaching (a) Jesus Christ's life, (b) ministry, (c) betrayal, (d) crucifixion, (e) resurrection, (f) ascension to heaven, and (g) ministry in heaven (p. 138). With the expounding of the scriptures, the people in the home received the message with clear understanding, especially on the wall of partition that separated them from the Jews. The meaning of the vision according to Peter and the people became so vivid in their minds.

Because of his focus on the gospel, the people experienced the manifestation of the outpouring of the Holy Spirit upon the Gentiles. The people in the house began to speak in tongues and praise God, and the Jews that came with Peter were shocked to find that even the Gentiles could receive the power of the Holy Spirit (Acts 10:44). According to their custom, the baptism of the Holy Spirit was a Jewish privilege; hence, it came as a surprise to them that Gentiles could also receive the Holy Spirit (Acts 10:45, 46). Peter then suggested that these converts be baptized because they had received the Holy Spirit as the Jews did (Acts 10:47, 48). 
Finally, the door the Jews had closed against the Gentile converts was now open.

Hence White (1911) further states that:

The time had come for an entirely new phase of work to be entered upon by the church of Christ. The door that many of the Jews converts had closed against the Gentiles was now to be thrown open. And the Gentiles who accepted the gospel were to be regarded as on equality with the Jewish disciples, without the necessity of observing the rite of circumcision. (p. 136)

\section{Inclusiveness}

The message was not for Peter alone; it was for all those that came to listen to the gospel. Peter remained in Joppa Joppa for some time in the home of Simon the tanner where he continued his ministry. When he was called to go and preach the gospel in Caesarea, he started in the home of Cornelius. Cornelius was a Gentile who worshiped God and sent messengers for Peter to come and preach the gospel. While in Joppa, Peter had a vision. He saw the heavens opened and a vessel coming down with unclean creatures for him to eat. Well versed in the Scriptures, he knew the difference between clean and unclean animals; he refused to eat unclean animals. God pointed out that any animal declared clean by God, was transformed into a clean animal. From that time, Peter was accepting of peoples outside the Jewish community. Hence, everyone in the house participated as Peter was preaching. The congregation, not Cornelius, asked Peter to continue preaching for some days (Acts 10:48). Everyone was involved in the process of conversion.

White (1911) states Peter explained the meaning of inclusiveness to the church leaders. Peter "laid the whole matter before them." He related to them the works of the Lord to the Gentiles through the vision he was shown. When they heard this account, the Jews who had converted to Christianity changed their minds and believed him. They 
discovered that they had a wrong perception of the Gentile converts, which was "contrary to the spirit of the gospel", and they glorified God (pp. 141, 142).

\section{Cross-cultural Skills}

It requires somebody with good communication skills to counter opposition. Peter faced strong opposition from the Jews, who were the circumcised Christians, for taking the message to the uncircumcised Gentiles (Acts 11:1-3). White (1911) states that Peter offended the Jewish brethren by visiting the home of "the unclean" Gentile, from their perspective. They feared that the association with the Gentiles would have an effect on the reception to his preaching (p. 141). Peter was direct and able to bridge the cultural issues that existed between the Jews and Gentiles.

\section{Summary}

Peter could be our model for initiating change. He obeyed God, and he underwent transformation. As a result, he exhibited a cultural sensitivity that he had not previously possessed. He was mission focused (task oriented), yet he included every member present in the change process. He was a good communicator. Therefore, Peter is an example of how leaders initiating successful change should first experience change in themselves before changing others. He was empathetic and sensitive to cultural issues.

The Seventh-day Adventist Church in Zambia is multicultural; therefore, there is a need for a leader to be culturally sensitive. The leader should focus on the mission in the process of change, even if other issues creep in. Such issues should not divert the leader in the process of change. The leader should involve church members in the change 
process and be empathetic to their needs. Above all, successful change takes place if the leader initiating change has good communication skills.

\section{Paul as a Change Agent}

Paul encountered many practices that hinder change. In this section, I am going to discuss Paul and cultural issues that hinder change in an organization. On the road to Damascus, Paul encountered Jesus before becoming a missionary. He had to adapt to Christian culture first (Acts 22:1-2) before going to other parts of the region. Sampley (2003) states he was both a Jew and a Roman citizen; therefore, he was able to write letters in Greek. The adaptability in Jewish and Roman communities made him communicate well to "various cultural mixed groups" (p. 25). In doing this, he was able to convince the people that he was not a persecutor but a disciple of Christ.

\section{Conflict Resolution}

As Paul started his missionary work, he encountered cultural issues that created conflict that hindered his work. In Antioch, he faced opponents on the issue of circumcision of the Gentile converts. White (1911) states that Paul and Barnabas preached in Antioch where many classes of people worshipped (p. 188). The wall of partition existed between the Jews and Gentiles. White (1911) further states that the partition bordered on Jewish laws and ceremonies forcing Gentile converts to accept the Jewish laws (p. 189). The cultural issue became a big issue for the church in Antioch, and for Paul and Barnabas.

The issue of the circumcision of Gentile converts was introduced by some Jewish Christians from Judea (Acts 15:1, 2) and caused contention. White (1911) observed that 
there was much discussion over the issue of circumcision of Gentile Christians (p. 188). The fact here is that from the onset of the cultural conflict both apostles and church members were involved in the process of resolution. The involvement of the members began from the onset of change - an important point to remember for leaders wishing to initiate change.

\section{Inclusiveness}

Paul used a small group of leaders to work out issues. This inner circle was comprised of apostles only. Nichol $(1978,6: 307)$ comments on the word "declared" in Acts 15:4 as it is compared with Acts 15:6, which implies that there was a small gathering before the large meeting. Nichol states that these texts "seem to indicate a preliminary meeting was held where Paul and Barnabas told missionary stories to the Apostles. This can be amplified in Gal 2:2, where Paul states that he met "privately" with "them." He addresses the rest of the laity delegates in Acts 15:6 as "brethren."

White (1911) states that the council discussed the issue before them and resolved "not to impose the ceremonial law on Gentile converts" (p. 194). Nichol (1978, 6:309) also comments on Acts 15:12 to say the emphasis here is placed on the fact that a discussion took place in the council, which included apostles, elders, and other members. This was after he discussed separately with apostles. In addition, James, who was the chair of the council, declared, "we should not trouble those from among the Gentiles who are turning to God" (Acts 15:19). 


\section{Educator}

Paul often found himself in a position of educating others. The Jerusalem Council was such an opportunity. He educated the church leaders on cultural issues (Acts 15:7, 12, 13). From his influence and teaching, Christians were educated as to how to live and practice Christianity. White (1911) states that "apostles and elders" agreed to go out and educate the Gentile Christians on the change that came from the Jerusalem council (p. 195), and Paul was one of the educators.

The changes that took place at the Council influenced the church worldwide. White (1911) states the change brought at the general council in Jerusalem made the cause of God to prosper (p. 197). The city of Antioch received additional messengers to Paul and Barnabas. These were Judas and Silas (Acts 15:25-27). White also states that Peter joined them at some time (p. 197). The workforce increased in the Gentile territory.

White (1911) states the church in Antioch was growing fast and was experiencing unity. Both Jews and Gentiles worshipped together. Paul and Barnabas assembled the Gentile Christian believers and taught them the mighty works of God done through their ministry (p. 189). The issue that was contentious had been resolved and the Jewish and Gentile Christians worshipped in harmony (Acts 15:30, 31).

\section{Confidence}

Paul faced resistance to change, but he had confidence in his ability to lead and trusted in the power of God. Leaders initiating change face challenges and often have strong resistance. Paul in his missionary work faced resistance from the elders. When the Jerusalem council resolution decided that Gentile converts should not be troubled with 
the Jewish law of circumcision in order to be saved, some of the Jewish elders were not pleased. White (1911) states the following:

Not all, however, were pleased with the decision; there was a faction of ambitious and self-confident brethren who disagreed with it. These men assumed to engage in the work on their own responsibility. They indulged in much murmuring and faultfinding, proposing new plans and seeking to pull down the work of the men whom God had ordained to teach the gospel message. (p. 196)

Even today, churches experience similar controversies whenever there is change, even if it is simply a change of programs in a department of the church. Not every elder in the church will accept change initiated by the church pastor and conference leaders. There will be those who will oppose and come up with their own plans and ideas to confuse the church. It would seem that they want to impose their plans and ideas on believers.

Paul also faced resistance from his fellow apostles and Jewish Christians, but not the Gentiles (Acts 15:31). White (1911) states that Paul "in a large measure, caused this change" from Jewish "ceremonies and traditions" to a new faith (p. 197).

Paul presented the change with confidence. Then, when Peter joined Paul and Barnabas at some time in Antioch, he also spoke with surety and gained the trust of the church members. Some disciples were not very pleased with the change of events at the council. White (1911) states "even the disciples were not all prepared to accept willingly the decision of the council" (p. 197). However, the outcome of the council brought great change in the history of the church. As is shown in this incidence, whenever there is change in any organization, resistance from some prominent pastors is inevitable. Some pastors are on the side of the opposition transition party. Hence, there is a need for the 
leader to speak with confidence and clearly communicate the need for the particular change.

Confidence on the part of a leader engenders trust in the members. It is necessary for leaders to address the fears of the members. For example, White (1911) states that the Jewish leaders feared that the Gentile Christians would eventually exceed Jewish converts. They also feared that the Jewish identity from other people in the region would diminish. They feared they would lose their standing as the divinely appointed nation among all nations of the world would disappear. They feared they would lose their outlined Hebrew way of worship that included certain rituals. They believed that God alone was the only one authorized to change worship specifications (p. 189).

All of the fears expressed by the new Christians were legitimate and very real to those expressing concern. Leaders have to listen and have the confidence to address the issues in order to have them resolved. The confidence of Paul made this transition possible.

\section{Clarifying for Unity}

The other issue Paul faced in his missionary work was disunity regarding the food offered to idols. This also became a hindrance to his missionary work among the Gentile Christians. Paul had ministered to the Corinthian church during his many missionary travels. Polhill (1999) observed that the city of Corinth was full of temples dedicated to Egyptian gods. Among other gods worshipped was Venus.. The issue of food offered to idols and idol worship "derived primarily from the Greco-Roman culture of the city" brought problems of disunity in the church (p. 233). 
Paul writes to the Corinthians and addresses their concerns. The discussion includes the explanation of strategies they were to follow when initiating change in order to have unity. Polhill (1999), commenting on 1 Cor 8 , explains that Paul agreed with their theology but modified it by introducing love and not "knowledge" (vv. 1-3) as a governing principle. "For the Christian, love is supreme; it governs all knowledge" (p. 242). He further directs them to acknowledge only one true God-the Creator of all things (vv. 4-7). They needed to have true knowledge of God, or the Gentile Christians would go back to idol worship, where they ate sacrificed food because of lack of "knowledge" of the Corinthian "strong" (p. 243).

\section{Summary}

There are principles from the leadership of Paul when he handled the issue of circumcision, which are:

1. The leader is to educate members on change initiated.

2. The leader initiating change should consult other leaders.

3. The leader initiating change should be inclusive of all the church members.

4. Leaders should not to impose change but educate the members.

5. Leaders are to be culturally sensitive.

As a leader confident in his calling and in the power of God, Paul was able to lead and influence the unification of the people.

An example in Zambia is a change that took place among the Ila people, who keep large heads of cattle. They slaughter some of the cattle for mourners to eat during a funeral. Some felt that the meat was offered for idol worship before it was given to the mourners. Even today, some Christian converts eat the meat at funerals while others 
refuse. This belief by non-Ila speaking people has hindered the message to the Ila people. The pastor and lay leaders who initiate change in such a situation as exists in Zambia should follow the leadership example of the New Testament church leaders,

\section{Ellen G. White and Change}

Introduction

Because the writings of Ellen $G$. White play an authoritative role in the Seventh-day Adventist Church, an explanation needs to be given as to how she initiated change in the church.

\section{Counselor}

The children of Israel were looking for a monarchy like the surrounding nations, contrary to God's principles upon which the nation of Israel had been founded as a theocracy (1 Sam 8:4-9). White (1958) explains that:

A theocracy is a government that derives its power immediately from God. The government of Israel was a true theocracy. That was really a government of God. At the burning bush, God commissioned Moses to lead His people out of Egypt. By signs and wonders and mighty miracles multiplied, God delivered Israel from Egypt and led them through the wilderness and finally into the Promised Land. (pp. 761-762)

White (1958) warns church leaders of some dangers that might come to them and their institutions if they advocate for change in their own way. She points out how the children of Israel were under the leadership of God, but He appointed Moses as their supreme leader. Appointed leaders received instructions from Moses and enforced the laws. However, they wanted a change of leadership and not a direct rule from God through Moses. They wanted to have a king like the surrounding nations. However, God "did not consent to a change in the principles upon which the state was founded" (p. 603). 
White (1958) further states God allowed them to have a king like other nations, and he gave them Saul. He permitted the children of Israel to follow their own choice when they rejected His authority. After the leadership of Joshua, sin perverted the children of Israel. They completely forgot their God who brought them out of the land of bondage in Egypt to the Promised Land where they could worship Him freely. Though there were judges appointed to lead them in day-to-day affairs, they still wanted to do things in their own ways. They went into intermarriages with surrounding nations. They also "adopted many of the customs of their heathen neighbors and thus sacrificed to a great degree their own peculiar, holy character" (p. 603).

White draws from the biblical examples to counsel leaders in the church. She says that those who do not want to change the existing policies and attitudes will, like the Israelites, reach a point where they do not want to listen to any counsel from God and the Spirit of Prophecy. Their aim is to maintain a status quo with no change.

White (1903) advised the sanitarium leaders to move out of Battle Creek. Time for change had come, and it was time to move the institution out of the city:

For years light has been coming to me that we should not center so much in one place. I have stated distinctly that an effort should not be made to make Battle Creek the sign and symbol of so much. The Lord is not very well pleased with Battle Creek. Not all that has been done in Battle Creek is well pleasing to him. And when the Sanitarium there was burned, our people should have studied the messages of reproof and warning sent them in former years, and taken heed. (RH, April 14)

This was another counsel on change that was rejected by church leaders that resulted in the burning of the sanitarium at Battle Creek. Therefore, to avoid a similar situation today, church leaders need to be cautious and prayerful as they seek guidance of the Holy Spirit. Pastors and lay leaders should not reject change because of status quo and putting their own interests ahead of the church. This puts their leadership in danger. 
Another example is when the leaders at the publishing house did not want to change their idea of moving out of Battle Creek. White (1903) foresaw danger in not taking the change of their attitude seriously and the following quote describes the consequences:

Before the fire came which swept away the Review and Herald factory, I was in distress for many days. I was in distress while the council was in session to get the right matter before the meeting, hoping, if it were a possible thing, to call our brethren to repentance, and avert calamity. It seemed to me that it was almost a life and death question. It was then that I saw the representation of danger, a sword of fire turning this way and that way. I was in an agony of distress. The next news was that the Review and Herald building had been burned by fire, but that not one life had been lost. In this, the Lord spoke mercy with judgment. The mercy of God was mingled . with judgment to spare the lives of the workers, that they might do the work which they had neglected to do, and which it seemed impossible to make them see and understand. (RH, April 14)

Ellen White's counsel on change was not accepted when she told the people at the Review and Herald building the dangers that might befall them and the publishing house. Consequently, the fire destroyed the factory, and this was viewed as a punishment from God. Leaders initiating change need to adhere to the counsel of Ellen G. White.

\section{Persistence and Determination}

White tried to initiate change that was at times rejected with terrible consequences, such as the previous example of the burning of the Review and Herald building. She understood that changes needed to take place; yet, her advice was often not followed. She did not give up. She understood the need for change, but she also understood that the people must choose to accept the guidance.

White advised that positive change can only be achieved if the pastors and the lay leaders are in harmony with the will of God. White encouraged prayer and meditation on the part of leaders; thus allowing change to take place in their minds first. White's 
willingness to once again give advice regarding the need to move an institution is an example of her persistence. According to the record, White (1903) gives counsel to the leaders to move the school out of Battle Creek. She said that it was time for the leaders in Battle Creek to accept change:

For years the warning has been given to our people, Get out of Battle Creek. But, because of the many interests established there, it was convenient to remain, and men could not see why they should move. At last, Brother Magan and Brother Sutherland began to think of the advisability of moving from Battle Creek. They came to me, asking what they should do. I said, "Take the school out of Battle Creek, if you can possibly do so. Go out into a place where there are no people who believe as we do, and there establish the school on a location with plenty of land, that the students who come may be educated in right lines." They obeyed the instruction given. This was the first move made. It has been a success. God has been pleased with it. He endorsed the effort made to get away from the congregation of Battle Creek. (RH, April 14)

This move would possibly have been delayed with disastrous consequences had Ellen White not persisted in her counsel. She warned against the mentality of holding the school at Battle Creek, but at first, it was not accepted. Finally, the school administrators listened to her counsel to move the school to the countryside.

White did not give up and stop giving counsel, when leaders failed to accept her directions. Today, we must be careful not to do the same. In addition, as leaders we must not give up when we feel our particular counsel has been rejected. A counsel that might be applicable to today and to the church in Zambia is the advice White (1915) gives stating that church leaders should not be laboring in the same church, district, even as conference president for so many years but to change positions. She encourages change of gifts as a good sign of church growth. Furthermore, church leaders should understand the reasons for changes, and if they do, they would not refuse to labor in other places (p. 420). 


\section{Summary}

Ellen White served as a counselor to leaders, but her visions received from God were her guide. She does not share capricious thoughts of her own, but through prayer, study, meditation and understanding, she led and counseled. Her willingness to continue to share counsel and guidance from God, in spite of her advice being rejected by church leaders, should be a comfort to leaders today.

\section{Conclusion}

\section{Elements of Initiating Successful Change}

As demonstrated in the lives of the leaders in the Old Testament and the New Testament, pastors and lay leaders initiating change must be people who have a relationship with God, people of integrity and patience. In some cases, biblical leaders had to learn inclusiveness and acceptance of all peoples. God used their innate gifts, but He also developed the needed changes in their leadership, such as the case where Moses was led by Jethro to change his style of leadership.

The ability to communicate is important, but as seen in the life of Ellen White, even clear communication can be rejected. White is an example of someone who did not lose courage, but instead she was persistent and determined to share God's message and

counsel. This exemplifies the need for leaders to learn to accept God's leading as well as the need to accept the listener's power of choice.

Jesus was the ultimate example of a leader who exhibited active listening skills. He listened and responded to the needs of those who appeared to be interrupting His mission. He stayed focused, but He brought the people with Him as evidenced in His triumphal entry into the city of Jerusalem. 
Practical applications can be learned from the biblical leaders and Ellen White. Church members should trust their leaders; church members should have confidence in their leaders. The leader's character should be exemplary to the church and the community. Joseph overcame all the problems he encountered in his life by maintaining the purity of his character and trusting in God.

Pastors and lay leaders should be credible leaders for them to be successful in initiating change. In leadership, experience and ability to lead are guides to making better decisions for the church to move in the right direction. Therefore, the leader initiating change must show leadership credibility, which includes administrative skills and member-leader confidence.

Pastors and lay leaders initiating change should be good listeners for the body of believers for it helps to be able to synthesize information as it comes from the members; it will be relevant to both the leader and members. It is important for leaders initiating change to have a listening ear and allow others to speak. The leaders mentioned in the discussion used the listening skill in solving the problems. All leaders can develop this skill.

Pastors and lay leaders initiating change should allow discussion and consultations from church members. Church members should not be isolated but included in the process of change; in doing so, the change will more likely succeed and be supported.

Pastors and lay leaders initiating change should understand change does not come by coercion but through the guidance of the leader. Change comes with humility, patience, education, and the winning of confidence. The leader must also obtain the 
consensus of the people, perhaps meeting first the board of elders before going to the church business meeting. The people and the leader must agree to change and not just have one group impose it on another group.

The most important lesson to be learned from the leadership examples in this chapter is that of the love principle. If leaders accept what Peter learned, that all people are equal; if leaders accept what Jesus taught, that all people are worthy through His life and death for them; if leaders use an educative process to guide the people; if leaders will first obey and be transformed by His power, the love principle will help facilitate change. 


\section{CHAPTER III}

\section{LITERATURE CONTRIBUTING TO A SUCCESSFUL INITIATING OF CHANGE}

\section{Introduction}

This chapter explores change theory literature by extracting information from what other scholars have written on change and the change process. Discussion of the information will be in the Zambia context. This will include anthropological literature on Zambian culture, which will help pastors and elders in initiating change. I will review current and relevant information from books, articles, journals, on-line data, newspapers, and available data from the Zambia Union Conference.

There are three major divisions in this chapter. The first section focuses on literature having to do with organizational change, mainly by asking such questions as (a) Why initiate change? (b) Where to change? (c) What to change? and (d) When to change?

The second section presents strategies for managing organizational change. In this section, the question is how to initiate change. The third section deals with change as it relates to culture. It is on literature from and about Zambia in reference to the practice of leadership in the family and church. Also included is a review of literature about the Western culture as it relates to Zambian culture and change. 


\section{Literature on Initiating Organizational Change}

Introduction

The discussion in this section focuses on the definition of change, nature and the factors of change. On the nature of change, I will focus mainly on reasons for initiating change in the organization. When it comes to discussing the factors, I will focus on where to change. This section I believe to be the stepping-stone to strategies for managing change in the organization. Meanwhile, I begin with the definition of "change."

\section{Definitions of Change}

Numerous writers have proposed various definitions of change. Gove (1986) defines change as the "action of replacing something with something else;" or "departure from a norm;" or a "religious or moral conversion" (p. 374). According to Pickett (2000), change means to abandon something and go for something new, and to undergo transformation (p. 310). Allen and Schwarz (2000) define change as a transition to a new system or change of attitude (p. 273). Mish (2003) adds to say change is the act, process, and taking a different direction (p. 206).

Macionis (2007) from a sociological perspective defines change to mean "the transformation of culture and social institutions over time" (p. 483). From the management point of view, change is transitioning of individuals, teams, and organizations from a current state to a desired future. These definitions help in the discussion and are all-important when initiating change.

Different scholars have written literature on change, and discussed different approaches on several fronts by answering such questions as:

1. Why initiate change? 
2. Where has the church gone wrong for change to be required?

3. When to initiate change?

4. How to initiate change?

5. What strategy should be used?

Such questions give guidance to the pastor and lay leader when initiating change in the church organization. Christian and secular scholars use certain elements when initiating change. I will develop these principles when dealing with nature of change. There must always be reasons why the pastor and lay leader initiate change in the church, and this must be the starting point.

\section{Nature of Change}

\section{Change is Biblical}

As discussed in chapter 2, the Bible is full of characters that initiated change as the environment dictated. For example, Joshua at the Jordan River initiated change when he told the children of Israel "for you have not passed this way before" (Joshua 3:4) and they moved without hesitating. As Mish (2003) pointed out, that type of change means to take a new direction (p. 206). So it was with the children of Israel taking a new direction where they have never been before. To the children of Israel, it was a new route and environment.

Change is transformation of ones' character. Youngblood (1986) defines transformation as "to change radically in inner character, condition, or nature" (p. 1274) of a person. This means the conditions surrounding an individual tends to change one's character. Weems (2003) adds that Gods' people change as the time comes to do so (p. 15). The events that take place also transform one's character. 
Gove (1986) said it right when stating that transformation is a religious or moral conversion, and that is life changing (p. 374). This experience is in one's actions or deeds. According to Herrington, Bonem, and Furr (2000), change is a central aspect of the Christian experience (p. ix). This is indeed an outward and inward experience of a believer in Jesus Christ. Lynn Anderson (1994) adds, "Everything being Christian means change" (p. 7). Being Christian is to change from those actions that do not conform to the Bible principles. Bridge (2002) adds that any "Christian or a church" that is not daily changed by works of the Holy Spirit is spiritually dead (p. 168). The Christian has to live a spiritual life daily. Herrington et al. (2000) believe that "the first step of the transformational journey is the leaders' own self-examination and willingness to be personally transformed" (p. 159).

Change means repentance. Youngblood (1986) defines repentance as "turning away from sin, disobedience, or rebellion and a turning back to God" (p. 1077). This is a change of direction in life. King Hezekiah's heart was filled with pride, but later repented of his disobedience and humbled himself before God (2 Chr 32:26). Nichol (1976, 3:302) comments to say Hezekiah repented and "accepted the will of the Lord." Before initiating change, the leader must turn away from sin.

Change means conversion. Youngblood (1986) defines conversion as "the initial change of attitude and will that brings a person into right relationship with God" (p. 296). The good examples include "the conversion of the Gentiles" that caused joy to all believers (Acts 15:3), and the sudden conversion of Paul (Acts 9:3-21). Lydia's conversion took some time (Acts 16:14-15) because she first heard of the apostles' 
messages before baptism. Pastors and lay leaders initiating change are to live exemplary spiritual lives that are in conformity with Bible principles.

\section{Change is Dynamic and Inevitable}

Change is dynamic. Mish (2003) defines dynamic in terms of "continuous and productive activity" (p. 389). The Bible refers to this as sanctification, a work of a lifetime or something that is ongoing. The same principle applies to organizational structures, as in the case of the Seventh-day Adventist Church in Zambia, which has gone through changes in organizational structures and programs since 1905 when missionaries brought the message to Zambia. The church has continued changing some programs.

Allen and Schwarz (2000) say dynamic is "any driving force instrumental in growth or change" and as a "pattern of growth or change" (p. 504). Correctly so, change in the organization must be a driving force in achieving the intended goals. The administrative force here could include the pastor and lay leader, the local/union conference, division/general Conference of the Seventh-day Adventist Church with new programs. Paulsen (2009) agrees with Mish that the world we live in is not on "stand still" thus the life of the church "is dynamic" and it is in motion always (p. 13).

Change is dynamic in the sense that it prefers new programs that meet the test of time. Lynn Anderson (1994) states that churches need to grow; otherwise, they will be using outdated programs and methods that make young people leave the church (p. 36). In the same vein, Sahlin (2007) states that the Seventh-day Adventist church "from 1913 through the 1940 's" had to change focus on evangelism to urban ministry to "reach immigrants and ethnic minorities" (p. 15). The church had to adopt new methods and approaches to evangelism. 
External forces encourage change in the church. Church buildings are in the community since members are part of the community. The community is not static; it is always experiencing changes, which also affect the church. Weems (2003) embraces this whole idea of changes in the community putting pressure on the church to change (p. 18). This means that a leader must be prepared for changes in the church as well. Pue (2005) says a leader must read the times and respond to changes that come about in the community (pp. 210-211).

Jones (2006) warns the church that we live in "a time of rapid and profound change"; we must therefore move along with it but cautiously (p. 15). Weems (2003) states that "we cannot become what we need to be by remaining what we are," but by rising to the test of time (p. 16). Sahlin (2007) adds a different perspective to Jones and Weems' views by stating, "urbanization is the reality driving most of the changes in our world" (p. 35). The push factor in rural communities and the pull factor of urban centers make change irresistible. We see this in developing countries like Zambia where large numbers of rural dwellers are pushed to urban centers in search of jobs. Traditionally, urban dwellers are also connected to the rural communities of their ancestry, and so there is back and forth movement resulting in changes of lifestyle. This cross-cultural interface results in change or modification in worldview. This shows there is no culture that is stagnant.

Leith Anderson (1990) advises church leaders that as the world is changing, "whether we like it or not, change is inevitable" (p. 11). Evison (2006) cautions that the hardest part for a leader is to bring what is seen out in the world or community into usefulness and the realities of the church. It is not always prudent to follow changes 
taking place outside the church (p. 28), but to think in terms of church growth and develop better strategies.

Leith Anderson (1990) observes that change is a chain reaction, that when one segment of life changes it affects the other, and this comes about the way change is handled (p. 11). Paulsen (2009) further states that the church "can't afford to ignore change" and church leaders (p. 13) must initiate this change. Lynn Anderson (1994) also adds that the church needs to change to become relevant (p. 36). Pappas (2009) agrees with Lynn stating that it is about time for change and the church should not be behind (p. 32).

White (1915) supports the idea of adjusting by stating that the church must not be 'one-idea' people doing the same things year after year; there must change in the work (p. 119). Pue (2005) emphasizes that the leader must be able to adjust or even be able to live by the change in the community (p. 210). Paulsen (2009) also agrees with Pue that the church needs to adjust the methods used with modern ones that relate to society (p. 13). We are living in the twenty-first century and need to move along with new methods as we initiate change.

Gangel (2000) states that people desire change because of "dissatisfaction with status quo" and "to put it more simply, people have to be somewhat unhappy with the present game plan before they will welcome a new one" (p. 98). This is common in the political world where people are tired of leaders who stay in power for years as such people want change from autocratic, monarch, dictatorship to democracy. In the church, it is rare to desire for change unless the pastors and lay leaders do so. On the other hand, 
change is inevitable because the changes in the political world and the church move in that direction when necessary.

Pastors and lay leaders initiating change in the organization should understand that change is biblical. Change involves transformation, repentance, and conversion of leaders before thinking of initiating change. For sure change is biblical, dynamic and inevitable because of dissatisfaction of some members. We have discussed the reasons for change. Still the question remains: Where should the leaders initiate change?

\section{Factors of Change}

In this section, I discuss the three factors of change, which are (a) winning confidence, (b) behavior change, and (c) servant leadership. Change cannot take place unless these factors are considered.

\section{Winning Confidence}

When initiating change the leader should not impose it but rather exert influence on the mind-set of the people. The leader must change his or her mind-set before the member will change. Kouze and Posen (2008) add that to have church members move along with the leader when initiating change it is important to "break old mind-sets" (p. 193). According to Sahlin (2007), first and foremost the leader must "mingle" with people and "win the confidence" of those he or she interacts with them (p. 7). This is achievable by building relationships with old members of the church. This kind of relationship will help the leader to know the dynamics of how the church operates. 


\section{Behavior Change}

Behavior change has to begin with the pastor and lay leader and then the church members. Downing (2006) suggests behavior change must start with the leader by becoming a servant of the poor, who are the most vulnerable in the community (pp. 20, 21). Sahlin (2007) states that in order "to overcome social and cultural barriers, it is necessary" for the pastor and lay leader "to learn new ways of thinking and behaving" (p. 39). I agree with Sahlin because the church in Zambia is multicultural. There is a tendency of some leaders to side with one culture in the church. This has to stop because it derails any changes initiated.

Owens and Valesky (2007) suggest the pastor and lay leader should also understand the behaviors of the church members in their social and cultural context because this is the key to the success of change (p. 80). They further state that to consider environment first because it is "evoking and shaping the patterns of behavior of the people in them" (p. 203). Think of how people in the community behave socially in the way they talk and act to one another. Similarly, church members behave the same way as the community behaves. This helps the pastor and the lay leader know how to approach the initiation of change in the church.

Kouze and Posen (2008) add that to have church members move along with the leader when initiating change it is important to "change existing behavior patterns" (p. 193). That is why Owen and Valesky (2007) suggests the behavior patterns must be watched because they influence both the choice for change and the amount of time devoted to implement the change (p. 364). 
In the spiritual aspect, Dubrin (2004) adds that behavior change of church members is necessary because those not influenced by the Holy Spirit will act emotionally, when they do not understand the need for change (p. 81). I agree with Dubrin because both the leader and members ought to change their behavior patterns in order to see a meaningful and successful change.

\section{Servant Leadership}

Apart from Jesus and Paul, Block (2005) states that Moses exemplified true servant leadership when he delivered the children of Israel from slavery in Egypt to the Promised Land under God's direction (p. 260). Moses humbled himself before the people, even when they continued complaining along the way to the Promised Land. Furthermore, Kohlenberger (2009) states that to be good change agents, it is good to start with a lesson from Jesus' servant leadership because He ushered in biblical equality without looking into race, cultural, age, and gender (p. 5). This is very important to the church leaders because the church in Zambia is multicultural and is tempted to be biased. However, when practicing servant leadership, the leader will not be biased for or against a certain race or tribe.

According to Block (2005), a servant leader does not use his or her position or personal gain to initiate change (p. 277). Pue (2005) reaffirms by stating that leaders using positions for personal gain tend to fail to bring change and resort to tearing down old programs (p. 205). Haffner (2005) adds a true servant leader must use his or her eyes "to notice the needs of people" (p. 27) before initiating change. Block further states that the leader must be a paradigm "of fidelity and virtue" by leading with an exemplified life (p. 278). This is what it means to be a true servant of God and the people. Therefore, 
when initiating change in the church the leader should exemplify true servant leadership as discussed above by different authors.

In addition, the leader must have a positive attitude before initiating change in the church. According to Herrington et al. (2000), the leader must first have (a) personal spiritual formation, (b) capabilities, and (c) the right timing to initiate change in the church (pp. 32, 33). Pue (2005) adds that to be successful in initiating change the leader must first (a) change his/her own thinking process, (b) remove fear, and (c) have ability to come up with a meaningful strategic plan of attack (p. 213).

\section{Strategies for Managing Change in the Organization}

\section{Introduction}

Initiating a successful change in the church is a difficult process to pursue. It is difficult for any pastor or lay leader because change affects the existing structure and culture of the people. Herrington et al. (2000) state that "change is difficult to initiate" because it requires someone to lead the church "toward a common destination" (p. 159). To achieve this goal, the pastor and lay leader need to adapt to the twenty-first century leadership skills and techniques during any transition. The leadership skills and techniques obtained through reviewing current literature will help leaders to move the church to better programs.

The pastor and lay leader initiating change should not just impose it on the members, but has to plan how to do it without causing much resistance. The leader should come up with meaningful strategies of how to initiate change. Therefore, this section deals with meaningful strategies set up by different authors. It starts with 
(a) initial stages to initiate change, (b) strategies that can work, (c) comprehensive skills that help, and (d) finally handling resistance to change.

\section{Initial Stages to Initiate Change}

Change can be initiated when there is a felt need in the church. The pastor and lay leader do not initiate change for the sake of just changing the existing program, even though it is relevant. Change only comes when the existing program becomes irrelevant. Bossert (2007) states that Wausau church was at a standstill without evangelism. However, they (a) welcomed change that brought the ministry of Christ forward, (b) improved their work for Him, and (c) now the church is evangelizing to young adults in the community (p. 12). The church saw the need to evangelize the young people in the community and used this insight as a strategy. Young people evangelized whom they thought were receptive to the Word of God and would share it with other youths in the community.

It can be argued, therefore, that change is initiated when people feel the need for it. This means that those affected by a situation should be involved in the talk about change. This brings unity to organizations.

Holberton (2001) observed that:

From experience, most change comes from the top but turning it around and getting the bottom part of the organization to take a leadership role in effecting change goes a long way to having the change initiative be successful. (para.14)

I agree with Holberton's observation because most of the changes come from the top to the bottom. For instance, change often comes from the General Conference of the Seventh-day Adventist Church world headquarters in Washington, DC. down to the local 
church. The pastors and lay leaders have no choice but to effect the changes in their churches because they come from higher up in the organization.

\section{Strategies That Work}

\section{Strategy 1: Assess Church Situation}

How can the leader initiate change? The pastor and lay leader initiating change should first assess the degree of the situation at the church. Heifetz et al., Grashow, and Linsky (2009) suggest that it is better first to (a) assess the situation, (b) take the best of the tradition, people identity, and history of the church and (c) incorporate them into the change situation (pp. 22, 23). In addition, the pastor and lay leader should "connect with the values, beliefs, and anxieties of the people you are trying to move" for change (p. 38). Furthermore, the leader should also (a) engage the church members, (b) find out "their strongest values," and (c) see if there will be any support by serving such values (p. 92). Assessing the situation of the church in various segments is very important when initiating change.

\section{Strategy 2: Communicate Your Vision}

Planning is very important if things are to move smoothly and for the benefit of the organization. The leader must lay down all necessary procedures for change to succeed. Questions to be asked in planning, especially when it is top-down change or bottom-up change, include:

1. Is it minor or major change?

2. Whom will I involve?

3. What is the mode of communication? 
4. What is the time limit?

5. What is it that to be achieved?

Schaper (2006) states that initiating change means vision casting, which is achieved through teaching the members of all age groups in the church (p. 39). I agree with Schaper because if the pastor and lay leader is to achieve a successful change it is done by educating members. Schmidt (2000) states that change is the result of vision casting to church members while the essence of leadership is about focusing to the future and what is near (p. 43). Once the members know the vision and understand it, they will support it. The direction of change must be clear to the members. The leader prepares the roadmap for the future, which involves changes in the church. Bossert (2007) states, "decline and lack of a shared vision can lead to sour attitudes and talk about everything and everyone" (p. 12). I agree with Bossert because when the vision is shared with the church members, the leader and the members work together for a common goal.

Holberton (2001) suggests that the pastors and lay leaders are to plan with care when initiating and implementing change in the church. In addition, the leader should assess the speed the church or organization can adopt the new change. Furthermore, with caution, "going too fast can be more painful than the change itself" (para. 13). When initiatives come from the top down and pastors and lay leaders are forced to make immediate changes without proper planning, the often achieve less as expected.

Pollard (2000) states that the leaders must know the true purpose of communication, which includes teaching and informing about upcoming changes (p. 22). Lynn Anderson (1994) advises pastors and lay leaders initiating change that communication is very important at every step taken because people are interested in any 
information about the future (p. 189). Accurate information should accompany any meaningful change initiated by the pastor and lay leader. Palmisano (2008) encourages leaders initiating change to "learn communication skills" because effective communication "not only helps deliver a concise message with clarity, but can also save lives" (p. 80). Dissemination of valuable information to the members is very important and this helps achieve the intended goal on change.

Anthony and Estep (2005) state that the leader must clearly (a) define the problem or issue, (b) state the desired outcomes, and (c) gather relevant information and materials that may include the historical and current condition of the church. In addition, "effective decisions require accurate, reliable, and current information" and there is a need to gather facts, and "engage in fact finding, collecting materials and insights" (pp. 226, 227). Gangel (2000) adds that the accurate information should include the past and the present (p. 78). Bossert (2007) suggests that it is important to make the information on change available to every age group of the church (p. 11). Pollard (2000) states that "the sharing of messages with the least possible distortions" should be within the context of a leader's own culture bearing in mind the "differences in age and gender, social status and goes along with the sender and the receiver" (p. 22).

Establishing good relationships with church members is another important way of communication. According to Kouzes and Posner (2008), the leader initiating change should establish good relationships with members who have more information regarding the change. They can be good sources of information (p. 175). When the leaders connect themselves to the members, they will be able to translate the information in a simpler 
way. Heifetz et al. (2009) contend that the leader must be able to translate the change in a simplified manner by giving out the purpose, strategy, and period (p. 241).

Listening to church members is also an important way of communication. Gangel (2000) states that listening is another important tool of communication because failing to listen is failing to carry out the responsibility (p. 114). According to Greenleaf (2002), to be successful in initiating change the leader must be able to listen to the church members' concerns about change (p. 31). Kouzes and Posner (2008) agree with Greenleaf that the leader initiating change must be able to listen to peoples' concerns either in person or on the phone (p. 175). Listening to the views of members enables the pastor and lay leader to adjust where possible. Weems (2003) adds that the leader "must always be open to adjustment and to the working of God's spirit in unexpected ways during the entire venture" of initiating change (p. 116). Heifetz et al.(2009) suggest that for the opponents to change they need to be loved and not be marginalized, silenced, or relieved from their duties, but their ideas need to be heard (p. 145).

\section{Strategy 3: Be Inclusive}

Anthony and Estep (2005) state that the leader initiating change should engage church members to participate through brainstorming and assess their ideas for the desired outcome (p. 228). One way members can participate in the change process is to identify the supporters and non-supporters of change. Heifetz et al. (2009) suggest making a list of potential supporters and opponents who are not in extreme opposition (p. 137). Having such a list will give the leader an opportunity to initiate change that will balance the views from both sides. Anthony and Estep further suggest the use of SWOT analysis (strength, weakness, opportunities, and threats) the targets (a) strengths, (b) the 
missing targets (weaknesses), (c) positive outcomes (potential), and (d) some risks involved (threats). All this can be done during a brainstorming session with members (p. 229).

This idea of brainstorming is supported by Knott (2006) stating that this is the time when leaders should be able to "identify the decision markers" who have the ability to influence others and are familiar with the proposal for change (p. 5). There are many such decision makers in the church who can be easily be identified. In most cases, the decision makers can be the rich people, managers in business houses, or even just influential people. On the other hand, Heifetz et al. (2009) further suggest that it is better to identify potential opponents who think they will lose something if the change succeeds and stay close to them and get their views as well (pp. 140,141).

A group can bring about change, and not just the pastor or lay leader. Gangel (2000) adds that "sometimes the best thing that can happen to a new idea is to give it away and make it group property. Participation depends on the sincerity and honesty with which we go about attempts to involve other people" (p. 99). Do not make the change to be yours but for the church. Boria (2007) supports Gangel stating that everyone is involved in group discussions and change needs to come from a church program not the leader alone (pp. 79-81).

\section{Strategy 4: Develop Other Skills}

According to Flikkema (2009), the leader must be skilled enough to initiate change and move along with the church (p. 11). One of the skills is to learn people's areas of concern. According to Elmer (2006), the best strategy the leader can take is threefold: (a) Learn about others to help adjust the changes where necessary, (b) learn 
from others to help promote trust relationships, and (c) learn with others to produce greater partnerships in change (p. 106).

MacDonald (2005) states when initiating change one must consider the following:

1. Historical values of the church

2. Age group relationships

3. Honoring the past

4. Awareness of those members who can kill any idea for change, while involving those supporting the change and advocates for the plan

5. Inviting a guest speaker on change to generate excitement by presenting meaningful "philosophy behind the change" (p. 51).

The other skill is to ask the elderly or old members of the church to help. In the same vein, Lynn Anderson (1994) quoting from Titus 2:1-5 that Paul shifted strategies as he moved from one culture to other and "expected the church at Crete to change and even said the older people should lead the charge" (p. 54). According to Pue (2005), it is good for the leader initiating change to "work with the 'old guard' in advance of the change" (p. 215). Engage the old people when you want to introduce change and make them as changing agents. MacDonald (2005) suggests that when initiating change the old members must have trust in their leader. The leader has to understand that old members are "less persuaded by logic" but "more convinced through love" (p. 54).

The pastor and lay leader initiating change must fully understand the nature of change. I mean to test the mood and reaction to change. The leader needs to develop this skill. This is a very important aspect when initiating change in the church, and it will be successful. Lynn Anderson (1994) advises leaders in order to minimize chaos when 
initiating change in the church or organization, "never underestimate the inflammatory nature of even the word change" (p.143). Instead of being wonderful, it can turn ugly. Understand change in the context of answering the what, why, and how of initiating change in the church. Lynn Anderson (1994) encourages leaders initiating change in churches or organizations to answer three questions:

1. What is it that I need to change and what has gone wrong with that which I need to change?

2. Why do I need to change it anyway if the people are comfortable with what they have?

3. If I need to change, then how do I initiate change that will be acceptable to the church without creating much resistance (p. 145)?

The pastor and lay leader will be able to answer the what, why, and how to change; then it is better to precede initiating change with caution. Tread softly and not to cause confusion and hatred for those that resist change.

Lynn Anderson (1994) advises the pastor and lay leader to proceed initiating change with caution as it is advisable to know the limits. These limits include (a) "you cannot change a person's tolerance for change," (b) "you cannot force people to change," and (c) "you cannot form people's perceptions for them" (p. 142).

According to Lynn Anderson (1994), it is prudent for the pastor and lay leader initiating change to come up with his or her own strategies and not copying other people's strategies because the needs of change differ from church to church. Formulate strategies according to the needs of the church. Furthermore, when initiating change the leader must carefully (a) evaluate the motive for change and (b) evaluate the current 
programs compared to what is to be achieved in the new program. The other aspect to initiating change in order to circumvent failure is for the leader to examine the "change implementation approach" (p. 142). The leader should ask: What approach am I going to use in this particular change? Approaches to initiate change differ according to the nature of change.

Lynn Anderson (1994) suggests that it is not advisable to "introduce the most important changes at the point of greatest risk" during the church service or large gatherings (p. 142). From my own experience in the ministry, such introductions have caused resistance to change. A good example was the resistance to the introduction of Women Ministry in Zambia Union Conference at a large gathering in Lusaka.

\section{Strategy 5: Understand Types of People}

The pastor and lay leader should be able to identify and understand the different types of temperament in the congregation. There are those in the church who grasp things fast, and there are those who take time to grasp things they are taught. When the leader initiates change in the church not every member will understand the change the first time it is presented. Some of the members will accept new ideas immediately while others need thorough teaching and explaining. Rogers and Shoemaker (1971) describe the types of people that are in the church:

1. Innovators (venturesome)-those who "are eager to try new ideas" and are good in communication, doing rash things, taking risks, and accepting failures if change is proven unsuccessful (p. 183).

2. Early adopters (respectable) - -these are good at giving out opinions, advice and information about change. They should be consulted before any new idea or change is 
introduced in the church. Early adopters are respected in the church because most of the ideas they support are successful. They are consulted by many change agents to reduce tension and make speedy decisions. Early adopters are considered the people to check "before using a new idea" (p. 184).

3. Early majority (deliberate)-these take a little time deliberating the new ideas but adopt them "before the average member of the" church does. They take their time deliberating the new idea but do not want to be in the lead adopting it (p. 184).

4. Late majority (skeptical)—-these "adopt new ideas just after the average member of the" church (p. 184). They are very cautious in making decisions of adopting the new ideas. They weigh all the norms of the church before they are convinced. They are also easily motivated to adopt new ideas by peer pressure (p. 185).

5. Laggards: (traditional)—-these "are the last to adopt" any new ideas or change. They are more traditional in their opinions because they always refer to past generations and that is when they make decisions on the new idea or change. They are always suspicious of new ideas or changes initiated by leaders. This group, because of their traditional inclinations, delay the process of change. While other members of the church are "looking to the road of change ahead, the laggards" have their "attention fixed on the rear-view mirror" (p. 185).

I agree with Rogers and Shoemaker in the above ideal types of people. These personality types are found in every church organization and should not be ignored by every pastor and lay leader initiating change.

Anthony and Estep (2005) state that the following ...dimension to the idea of change is the pace or degree of the change introduced into a congregation or organization. Gradual change: refers to small or incremental 
changes, minor alterations within the congregation or organization's existing administrative framework-change decisions made within the matrix of the mission, vision, and core values of the congregation or organization. Radical change: refers to large-scale changes, those that alter the very framework of the congregation-change decisions that reengineer the congregational and organizational matrix. (p. 208)

The pastor and lay leaders can handle the gradual changes in the church without involving all the church members. However, the radical changes require the inclusiveness of the church.

Lynn Anderson (1994) observes that some approaches might require a lot of time and methods and some are just simple announcements as discussed in the church board and business meetings. Change can take some time or can take place immediately with the pastors' or lay leaders' announcements during the church service. The bottom line is that it is better to initiate change "at an appropriate pace", especially when it might seem to be difficult; do not rush (p. 142).

Holberton (2001) adds that when changes are initiated the leader should understand that "going too fast can be more painful than the change itself" (para.13). Heifetz et al. (2009) further observed that change in many cases generates "chaos, confusion, and conflict, for yourself and others around you" (p. 206). Hobgood (2001) views resistance to be good for it gives opportunity for leaders to dialogue and bring a good result from the first proposal (p. 125). However, this is not always the case in the church organization in Zambia, more especially in East Zambia Mission Field.

\section{Why is There Resistance to Change?}

The following are reasons why some Seventh-day Adventist churches in Zambia resist change: 
1. Traditions-it is important first to define "tradition" as we have defined culture. Mish (2003) defines "tradition" as "an inherited, established, or customary pattern of thought, action, or behavior (as a religious practice or a social custom)" (p. 1325). According to Weems (2003), churches that are rooted in culture or tradition and have a long history of Christian faith resist change. Tradition is taken to be an important issue in the church and members are not used to change or "at least to thinking consciously about change" (pp. 14,15). Weems further states that the old members who have deep cultural background and a long history in the church have the capital to trigger an explosion of resistance (p. 51). While I agree with Weems about the reasons why old members with deep cultural background resist change, I also implore that even new members with conservative ideas also resist change. These new members, once they hold on to the tradition of the church, they would love to live by it always.

2. Approach to change-Gangel (2000) observes that leaders initiating change become arrogant and sometimes even abusive when they bang church member's heads against their "own ideas until they either submissively follow what" they "want or leave the church" (p. 93). From my own experience in the ministry, some leaders impose change on members, and those who do not like it may leave the church. Equally, conference leaders compel church pastors to either accept changes or leave the ministry. This was exactly the case with the introduction of Women's Ministry in Zambia Union Conference.

3. Fear-Bossert (2007) suggests that leaders initiating change should bear in mind that change brings conflict in the church because some members fear that things would be different from what they are used to and not sure if Adventist roots would be 
completely abandoned (p. 11). Pue (2005) agrees with Bossert that people resist change because of fear (p. 216). Gangel (2000) states that people fear the unknown even if they voted in favor of the new plan. They also have a fear of the timing or not having enough resources to make change possible (p. 94).

4. Loss-Pappas (2009) says people resist change because they will lose something important they loved so much (p. 96). Holberton (2001) adds that people resist change because they lose "power and influence." I agree with Holberton because this is the situation in some churches in Zambia, where some leaders fear they will lose positions and status in the church. They would rather continue resisting change at all cost to maintain their positions. Heifetz et al. (2009) states that "it is not really true" that people resist change instead they "love change when they know it is a good thing." People only resist "loss," because they want to hold to what they have already (p. 22). Gangel (2000) state that when people "begin to sing only praise choruses from slides on a screen or wall, people have lost the hymnal... If we lock the organ and bring on the worship team guitars, people have lost something they loved. So we need to be careful here" (p. 93).

5. Status Quo-Matandiko (2001) suggests that women in Zambia resist change because Women Ministries and Dorcas Society are the same and would rather not accept the new department plus continue with Dorcas society (p. 174). Heifetz et al. (2009) add that people resist change because they are not "convinced by logic and facts;" hence, "they prefer status quo" (p. 22). Pappas (2009) adds that people resist change because "they are comfortable with what they have" (p. 12) and the leader is not reaching the people's heads and hearts (p. 38). I agree with Pappas because the pastor or lay leader did 
not communicate well the reasons and benefits for change. Ridley and Goodwin (2003) also add that people resist change because it will "cost them time and effort through the process of change" (p. 26).

Ridley and Goodwin (2003) state that resistance to change sometimes "occurs when an individual or group of individuals obstructs the flow of organizational energy moving towards a changed future" (p. 19). On the other hand, people are comfortable in their usual environment and naturally are inclined to resist any change that may come (p. 19).

6. Condemning attitude-Gangel (2000) observed:

Leaders tend to react negatively when someone opposes their plans or programs. However, frigid reaction to resisters can never facilitate the thawing process. If we condemn our opponents, common ice cubes could change into dry ice and doom all prospects of change. (p. 98)

\section{Handling Resistance to Change}

Gangel (2000) states "many people feel uncomfortable during a change even if they voted to go ahead with it. The awkwardness can come from several sources but arises most often from the way the leadership team approaches the change" (p. 92). Gangel (2000) further states:

In my opinion we become arrogant and even sinfully abusive when we bang people's heads against our own ideas until they either submissively follow what we want or leave the church. The way some leaders handle change, awkward probably doesn't adequately describe how a congregation feels. (p. 93)

Gangel (2000) continues:

To calm such fears, good ministry coaches emphasize spiritual peace and prayer.... Keep the goals in clear focus, and relate everything to the organization's mission. Help people raise their capacity for change and thereby help them adjust their attitudes. (p. 94) 
Handling resistance to change requires skill to remove fears in the minds of the church members. According to Heifetz et al. (2009), (a) love them, (b) spend time with them, (c) explain the need for change, (d) discuss how painful it will be and (e) get their views (pp. 140,141). With such a humble approach to those that oppose the change, your supporters "have more positive feelings about" the leader and his or her initiative for change (p. 145).

According to Gangel (2000):

When the game plan changes, people tend to focus on what they have lost, not what they will gain. The greater the change, the greater the loss. We need not argue about whether that response is good or bad, mature or immature-we need only recognize its reality. If we begin to sing only praise choruses from slides on a screen or wall, people have lost the hymnal.... If we lock the organ and bring on the worship team guitars, people have lost something they loved. Therefore, we need to be careful here. However, as a leader you cannot ignore the issue of loss in people's response to change. And we ought not to associate change with age. (p. 93)

Boria (2007) urges leaders to diffuse the hardened status quo by bridging the age groups and involving them in discussions on change (pp. 79-81). Gangel (2000) states:

Falling back on the familiar is common behavior for all of us. ... Most people find it hard to throw away a comfortable pair of old slippers or even trade in a car or truck that has served them well for many years. And the past is not bad or wrong just because it is older than the present or the future.... When people corporately hold on to the past, we should neither rebuke them nor shun them. We celebrate with them and together realize how the past has become a gateway to the future, a bridge to tomorrow. (pp. 95, 96)

\section{Change and Culture}

This section discusses the definition of culture. The pastor and lay leader should not ignore the culture of the church and community when initiating change. It is important to understand the context of the norms of the church and community in which they apply. In addition, the discussion will focus on the Western and African leadership structures and culture. Thereafter, the discussion will also focus on Zambian leadership 
structure and culture. Finally, the discussion will focus on the impact of culture in the church.

Many scholars, including anthropologists, sociologists, and many others, debated extensively to find the meaning of the word culture. Mish (2003) defines culture as "the set of shared attitudes, values, goals, and practices that characterizes an institution or organization" (p. 304). Owen and Valesky (2007) define culture as "the shared philosophies, ideologies, values, assumptions, beliefs, expectations, attitudes, and norms that knit a community together" (p. 192). Macionis (2007), the sociologist, defines culture as that which involves "the ways of thinking, the ways of acting, and the material objects that together form a people's way of life" (p. 40). Northouse (2007) defines culture "as the learned beliefs, values, rules, norms, symbols, and traditions that are common to a group of people" (p. 302). Moran et al. (2007) define culture as a "means of adapting to circumstances," while at the same time maintaining a "sense of who they are," and "how they should behave" (p. 6). According to Weems (2003), culture is "who we are and how we do things around here" (p. 59).

\section{Culture is Learned}

Pollard (2004) in his study discovered that from birth, people learn culture through the mother, family, socialization, environment, and in cultural groupings; they share values (p. 21). Northouse (2007) adds that cultures are learned (p. 302) in the community or organization. According to Heifetz et al. (2009), they found that "cultures change slowly" like a child learning how to speak the language of the family (p. 17). When new members come into the church organization, they will have to learn the culture of the church although it takes some time to adapt to it. 


\section{Cultural Differences}

One other aspect to consider in this discussion is cultural differences in churches. For Pollard (2000), cultural differences are shaped by (a) differences in people's values, (b) basic cultural assumptions, (c) in the way they perceive reality, and (d) in their views of what is right or wrong, good or bad, ideal and desirable (p. 22). Most of the churches in Zambia Union Conference are multicultural; therefore, pastors and lay leaders should use the Christian culture that unites all the different cultures of the church. The Word of God should be the base of the Christian culture. The Christian culture includes the beliefs and values of the Seventh-day Adventist Church. Sahlin (2004) adds that the leader initiating change must "understand the local culture, the needs of the people, their values and religion," and then develop a meaningful "strategy contextualized to the local situation" (p. ii), but again should be based on the Word of God.

Western and African Leadership Structure and Culture

\section{Western Leadership Structure and Culture}

Robin Williams Jr. states that the values of American culture include (a) "equality of opportunity," (b) science to solve their problems, (c) individuality in pursuing their goals and not collectiveness, and (d) judging others according to race and gender (as cited in Macionis, 2007, p. 47). Pollard (2000) adds that low-context cultures, mostly found in Western countries, are (a) time and task oriented, (b) information focused, and (c) individual oriented (p. 22). Moran et al. (2007) state Western culture believes in equality and self-reliance; "they are a noncontact culture and maintain certain physical 
and psychological distance with others" (p. 682). Finally, husband and wife do not impose decisions on the other since they are all equal.

\section{African Leadership Structure and Culture}

The African leadership structure and culture differ in many aspects with that of the Western culture. Muganda (2000) observes that in the African set-up, people and their culture are respected (p. 48). The church leader initiating change in Africa must consider the leadership structure in the context of culture. The people come to church with their culture, and it takes time to abandon some ways of life that are not in accordance with the Scriptures.

Family unit

Muganda (2000) further explains that the African culture is a strong social unit based on extended family linked to a larger society of the same clan. Furthermore, from a family unit there comes an extended family built on a single kinship called a village united by elders. In the village, grouping the "aunts and uncles play a very important role in cementing families" (p. 44). Moran et al. (2007) support this family unit structure when they state, "the basic unit of African society is the family, which includes the nuclear family and the extended family or tribe" (p. 614). There is no such family unit in the Western culture.

Tribal grouping

African tribal groupings are families larger than Western or European family. Smith and Dale (1968) in their study discovered that tribal groupings are families larger 
than the normal Western family consisting of about twenty-five members (p. 284). Muganda (2000), with his African family experience, adds that such a "community supersedes the individual," also known as mukwashi meaning "us together" and as opposed to Western individualism (p. 47).

Family elders

Muganda (2000) states that elderly people deserve respect because the advanced age is equivalent to wisdom (p. 44). Moran et al. (2007) agree with Muganda when they state that age is an important factor in Africa, because it is also "believed that the older one gets, the wiser one becomes" and the elders need to be respected (p. 617). Muganda further states that the family, the clan, and the whole village value their leaders, their counsel and "are given top priority in every social activity" (p. 44). With my experience in ministry, such elderly people who once came to church still carry that level of respect and their counsel is still sought. Moran et al. (2007) alluding to Mugandas' statement they compare the African set up and the Korean where "elders in Korean society are always honored, respected" and "age allows an older person to influence the opinions of others" (p. 475).

According to Muganda (2000), the leader initiating change must "value oral tradition" because people in the community value stories and illustrations and change must be based in that context (p. 44). I agree with Muganda because family elders transmit this oral tradition to the younger generation. Even if the family elder becomes a Christian, he will hold and transmit oral traditions for generations to come. 


\section{High-context culture}

In his research, Pollard (2000) discovered that most African countries are highcontext cultures that focus on events over time and emphasize relationships more than message. Kenya is a good example of a high-context culture (p. 24). Even in Zambia, an event is more important than time. Muganda (2000) adds that in African culture

(a) communication with people is first, (b) then the task, (c) choice of words,

(d) explaining ideas, (e) way of expression, and (f) personal feelings are respected with gentleness (p. 48).

African religion

Ndung'u (2008) discovered in his study that African Christianity has integrated two influences running side by side and these are "the Christian teachings and their African culture." The latter has taken precedence because Christians tend to "revert to the traditional customs for solutions" (p. 72). The only way to change the influence of African culture in the Christian community is to do as Chu Ilo (2007) suggests-cultural experiences in Africa must be understood in the context of light and truth of God's manifestation of Himself in history (p. 187). That is the only way to take the Gospel through cultural experiences.

On the positive side, Bauer (2010) states that people worship, praise, and express their faith in God "through their local culture" shaped by "cultural meanings, feelings, and values" (p.172). Harper and Metzger, (2009), add that culture is also responsible for distorting our perception and understanding of God by shaping them in ways that are cultural rather than biblical" (pp. 33, 34). 
I have noted that the Western leadership structure promotes equality of husband and wife. Extended family is not a priority at all. In the African leadership structure, however, the husband is the head of the family, and there is respect for elderly people. Having discussed about the Western and African leadership and culture, our focus is on Zambian leadership and culture.

\section{Zambian Leadership Structure and Culture}

The Zambian family has large social structure units and on such all social service programs are organized. The elders in these social structure units are the authoritative figures of the family and sometimes of the clan. Although women with age gain more say in the family, they are subservient to the will of the male head of the family. Sons get first priorities in almost all areas of decision making. However, they do provide good education for their daughters ("Zambia Women," 2009).

Men have most of the power. There has been an effort to gain greater influence for women's rights, but it is difficult to incorporate programs that change traditional beliefs ("Zambia Culture," 2009). The trend today has changed but not significantly:

Throughout its colonial and post-colonial history, Zambian women have always been treated with a little lesser respect than men folk. The cultural orientation of Zambia being male dominated and patriarchal, women were not given their due respect and position in society despite making significant contributions to it. ("Zambia women," 2009)

Smith and Dale (1968) observed that the typical Zambian family unit "consists of a man, his wife or wives, their children, the children under his guardianship, sometimes an aged parent" (p. 283). On the other hand, Randal (1970) observed, "both the husband and wife share in making decisions" (p. 124). Contrary to Randal's observation, Colson (1958) argues that in the household of a married couple, the husband has the authority in 
making decisions and normally referred as "the owner of the house" (p. 105). While this is true it all depends on which part of Zambia where you draw your observations, but in general, the husband has the final authority in decision making. The Zambian social structure has three levels. They are presented in ascending order.

\section{Household}

Raelly (1981) observed that the "family structure of the Zambian community still holds" (p. 48). This is referred to as a household (mukwashi in Ila, ing 'anda in Tonga and Bemba, $n g$ 'anda in Ngoni, and $n d u$ in Lozi). Hence Shewmaker (1970) defines the Zambian household as a "group of people which gathers about a common fire and usually consists of a single adult male and female and their offspring" and tells lovely stories about their ancestors (p. 17). Raelly concludes by stating that the Zambian households "are dependent upon each other" and share all things in common (p. 49). The next stage in the Zambian structure is the village, which is larger than a household is. In the household, the husband is the head and makes decisions.

\section{Village}

According to Randal (1970), villages are made of households and usually are large, and those considered as large "contained 863 people" while the average village contained 135 people (p. 116).

As stated earlier, in the household the husband makes decisions. Randal (1970) in his study of Zambian peoples discovered that, in the village all decisions are made "by the headman, with the help of the elders" (p. 124). Moran et al. (2007), from their study, support Randal and state "the village elders become judges, mediators, trade masters, and 
leaders within both religious and tribal life" (p. 614). I add to say the village headman will make a final decision after consulting some senior elders, or the inner circle.

\section{Chiefdom}

Several villages combined make up the chiefdom and are under one chief. There are some territories in Zambia ruled by several chiefs with one paramount chief. This is the case with the Bemba in the Luapula, Lunda in the North Western, Lozi in the Western, and Ngoni in the Eastern provinces. The sub-chiefs do not make final decisions without informing the Paramount Chief. Bilima (1993) points out that the Paramount Chief orders his "ndunas" (counselors) or sub-chiefs to convey his messages (p. 110). Chiefs or Chieftainesses control and direct Chiefdoms. The Chief or Chieftainess has absolute power, wealth, and influence in the whole chiefdom ("Zambia culture," 2009).

Once these leaders of the community are in the church, they have a greater influence to their subjects to be members of his or her church. Above all, they will have a greater influence in the business of the church. Therefore, leaders should not ignore such people when initiating change.

\section{Impact of Culture in the Church}

According to Kaplan (1979), Zambia has about seventy-three ethnic groups and all these speak different languages (p. xiv). This makes the church in Zambia to be multicultural and change must go along these lines.

The impact of culture on the church persists even today, causing the church to react to some practices. The church in Zambia condemns kukwenzha (men mourning the dead with spears), kulamba (women mourning the dead by smearing with ashes), and 
chisungu (maturity and counseling of a girl) of the Ila converts. Furthermore, the church condemns the use of traditional musical instruments such as malimba, kalumbu, namalwa accompanied with kuyabila, ingoma during worship services. The instruments that the church allows during worship are western instruments such as a guitar, keyboard, organ, piano, xyraphone, accordion and many more. Some churches do not allow women to be in the baptismal pool with plaited hair. In addition, some churches counsel women to put on a headdress during Holy Communion.

\section{Cultural Practices}

Santrac (2010) observed that "the church had a tendency to condemn, or at least criticize, various cultural issues that were situated in direct opposition to the spirit of the gospel as revealed by the totality of the Bible" (p. 27). The church should test every cultural practice with the Word of God to determine what should be accepted, rejected, or discouraged.

The Zambian church can use its culture in worshiping and praising God without conflicting with the Word of God. Leaders can tailor some of these cultural practices to the biblical way of worshiping God and evangelism. This study is to help pastors and lay leaders become skillful in initiating a successful change without merely condemning the culture of the people. Some of the cultural practices and beliefs can be used as bridges for effective evangelism.

The following principles as stated by Pollard (2000) can be useful in cultural situations:

1. Know the meaning of words that are used in that culture. 
2. Know the content and context of the message bearing in mind the high- and low-context cultures.

3. Identify yourself with members in the setting of their culture so that they know you are with them (p. 24).

Pollard in the above section deals with cross-cultural dialogue, suggesting ways by which one can understand what goes on in a culture. However, Pollard does not say how one determines what is acceptable in cultural practices. Ncube (In personal communication, May 25, 2011) suggests the following principles as a guide to a Christian response to cultural practices:

1. There are practices like drinking beer that the Bible condemns. They should be out-rightly rejected.

2. There are wrong practices that will change in time as people's worldview changes.

3. Some practices are in the gray area, where there is no clarity one or the other. In this case, no decision can be made.

4. Then there are practices such as drinking caffeinated drinks that are neither a test of faith nor of fellowship. Education or teaching is the answer here. The individual makes the decision.

Further, Ncube (1988) suggests that Christians have to internalize the gospel message so they can make decisions on their own without relying on leaders to tell them what to do. This is based on the new covenant principle in Jer 31 (p. 135). 


\section{Role of Local Leadership}

Every church organization has its own bylaws and ways of governing the local church/district. According to Weems (2003), the power of doing all these things is in with the people of that particular church. They know how they do things in that church, and of course, this is a negative experience when initiating change. Furthermore, "a local church culture is often the first line of defense against change" (p. 61).

In such circumstances, pastors and lay leaders would try to react by changing the people's culture. Weems (2003) asks an important question that should be answered by every leader- "Does the culture permit the church to fulfill its primary task" that is missionary in nature (p. 61)? Therefore, leaders initiating change are to be cautious on change and culture. Learn the culture of the church before initiating change.

\section{Role of Women}

As discussed earlier on culture and tradition, Gashugi (2010) observed, in his study on the influence of culture in the church, that "the capacity of a female church member would be restricted" by cultural norm (p. 86). I agree with Gashugi's assertion because the leadership of men in the family and society is the general norm of the rest of Zambia and in the church. I have also observed that because of the cultural norm women continued to play a low profile in decision-making process even in the church. Hence, Watling (2002) implores that women must be involved in any forum of the change process and once involved in the process they "may enhance the ability of religion to negotiate change" (p. 533).

In chapter 1, the example the role of women in the church as presented at the Zambia Union Conference was discussed. Vyhmeister (2008) confirms in her research 
"women in some churches in Zambia are not permitted to preach" from the pulpit on the Sabbath day (p. 36). In East Zambia Field, churches disbanded because men in these churches could not allow women to preach according to the cultural tradition of the church.

Matandiko (2001), serving as Zambia Union Conference President at the time, gives a practical example where attempts to introduce women's ministries in Zambia met with resistance from laity because of various charges that were advanced, such as it "was introduced by some Jesuits," and "promoting the political wing of the women liberation struggle" (p. 175). In the same vein, crossing Chipata border into Malawi which has the same cultural norms as the Ngoni people in Eastern Zambia, Dabrowski and Bilima (2000) discovered that in the vicinity of capital city of Blantyer, two churches were disbanded because they did not want women to preach from the pulpit at the Sabbath main service (p. 19).

Many reasons may be given for reasons that women should not stand and preach from the pulpit during the divine service, such as influence of the Jesuits, women's liberation, and others, but the bottom line is the cultural norm enshrined in the Christianity found in Zambia.

I consider this discussion very important because change can only be successful when initiated in the Zambian context as long as it does not conflict with the Scriptures, Spirit of Prophecy and church organization. Kim (2004) states that "in this changing climate of today's church and theological education," women must be involved in preaching and teaching of the gospel, and in all aspects of church growth (pp. 2-4). 
Pappas (2009) adds that "culture continues to shift" and women must preach God's Word (p. 32).

Kohlenberger (2009) states that "culture characterized by social status and power" was not Jesus' plan but supported biblical equality. Jesus fit well into all cultures of His time. Elmer (2006) adds biblical equality be understood in the present and local context and through (a) "openness in everyone in the new culture, (b) demonstrate acceptance, (c) build trust and (d) learn from others" and (e) look "more Zambian among Zambians" (p. 109).

\section{Summary}

Change is all about people's culture. Change transforms culture and social institutions over time. Change is biblical. The world is changing, the community is changing, and the church is changing. Initiate change as soon as there is a need. Formulation of strategies to foster a successful change is very important. Expect resistance to change, and the leader needs to be prepared. In the event of resistance to change, the leader should know the temperaments of the people.

It is prudent in these circumstances to understand the changing world and adapting the culture of the community served. Successful change must be in the context of the local culture with strategies gradually put in place. In the Zambian culture, the leader initiating change has to (a) adopt a friendly attitude, (b) be trustworthy, and (c) adapt to the prevailing culture. The strategies must include the behavior change of church leaders and members as they do away with status quo. 


\section{CHAPTER IV}

\section{ANALYSIS OF LEADERSHIP AND \\ CHURCH GROWTH IN ZAMBIA}

\section{Introduction}

Chapter 3 discussed how the Zambian social structure is organized. Wood (1961) states that before the Europeans came, the lifestyle in the tribal areas was (a) strictly regulated according to custom, (b) properly organized in family groups and (c) democratic in choosing the headman and the chief. Meetings of the older men decided family and village matters. Chiefs were men of intelligence and had the ability to lead (pp. 80, 81). Even today, older men in the community, village headmen, and the chiefs are highly respected by the locals.

\section{Contributions of Missionaries}

According to Mish (2003), a missionary is one sent out as an agent to propagate religion (p. 1571). A missionary is one sent by the organization to go and preach the Word of God to a foreign land or within the country from one province to another.

When missionaries first came to Zambia in 1905, they came with skills to train and advance the social life of the locals. They came to teach the locals the Word of God. They had to learn the culture of the Zambian people in order to share the Christian values. 
The method used by these missionaries was to adapt to the local culture. They learned peoples' culture. They shared their skills by establishing new institutions such as clinics and schools. The training of the mind meant that Seventh-day Adventist primary schools were opened in every province of Zambia. The spiritual training meant the mission stations were opened in some provinces. The physical training provided clinics and hospitals for healthful living of the locals. The physical training did not just provide healthful living among the locals but also new methods and tools in agriculture. The missionaries taught carpentry and building. They trained people to be church leaders as well as Bible teachers in mission schools.

These missionaries had one thing in common-they were all Christians. However, not all missionaries had leadership qualities. They used various methods and approaches to reach the locals by establishing institutions. Wood (1961) states that the missionaries "established their little stations, churches, schools, and dispensaries to win the heathen over to the grace of Christianity" (p. 53). According to Kaplan (1979), missionaries used prophets and priests because they "had significant influence" to the locals as they were considered direct descendants of the high god (p. 98).

By and large, the coming of the missionaries had a positive effect on the locals. Kaplan (1979) states Christianity opened doors to education (literacy, crafts, and skills), which was essential to their future and an escape from existing social constraints (p. 100).

\section{Leadership Development}

This section deals with leadership development in the Zambia Union Conference. When looking at the number of pastors from 1992 to 2010, Table 1 below indicates the development in church leadership. In 1992, the total number of pastors in Zambia Union 
Table 1

Zambia Union Conference Leadership Comparison Statistics

\begin{tabular}{lcc}
\hline & \multicolumn{2}{c}{ No. of Pastors } \\
Conference/Field & $\mathbf{1 9 9 2}$ & $\mathbf{2 0 1 0}$ \\
\hline South Zambia & 32 & 38 \\
\hline Central Zambia & 32 & 64 \\
\hline Copperbelt Zambia & 28 & 35 \\
\hline North Zambia & 34 & 12 \\
\hline Luapula Zambia & - & 13 \\
\hline West Zambia & 24 & 18 \\
\hline East Zambia & 12 & 13 \\
\hline Zambia Union Conference Totals & 170 & 193 \\
\hline
\end{tabular}

Note. Adapted from Don F. Neufeld (1993) and Zambia Union local conference/field Executive Secretaries, May 23, 2011.

Conference was 170 as compared to 2010 when the total was 193 . These figures do not include pastors at the union office. These figures indicate a slight increase of 23 pastors in the period of 18 years. This means the calling of pastors to full time gospel workers was limited. The limitation was due to criteria used to accept someone into the ministry. The prerequisite to full time gospel work was one year in Literature Evangelism. The organization of Luapula Zambia Field was after 1992 from North Zambia Field; hence, the 1992 box is empty. In addition, North Zambia Field and Luapula Field there is a drop of the number of pastors from 34 in 1992 to 25 in 2010 (adding the two fields in 2010, a loss of 9). The reason might be the downsizing of pastors during this period due to 
financial difficulties, some re-directed to literature ministry, some for further studies and others called to serve in other conferences and fields.

There was also a time when the Zambia Union stopped sending young recruits for theological training because there were too many pastors already. It took Zambia some time to catch up with the demands for new pastors when others retired or left the ministry.

Analysis here considers two issues. First, holding to church and community traditions, the church was to preserve its cultural heritage in its understanding of 1 Cor $14: 34,35$. Members come into the church with strong Zambian culture, where women play a low profile in public. As earlier indicated in chapter 1, Zambia is male dominated with most cultures being patriarchal, and women have not been allowed to occupy positions of leadership in society. The church has also gone in the same direction with the community.

Secondly, there was an issue with the manner in which Women Ministries was introduced. Introducing this new department was the major problem to church leaders because of the strategies used. There is nothing wrong with the department and its mission. In my view, the resistance to change is as a result of a lack of skills and strategies in initiating change. The pastors and lay leaders have something to learn from the missionaries as to how they should initiate change to the locals in their contexts.

\section{Summary}

To introduce new programs in the church, it requires leadership skills that meet the challenges of the time. People should feel that they are part of the change process. 
The pastor and lay leader initiating change must (a) engage the situation, (b) learn, and (c) understand the culture of the people.

\section{Profile of Zambia Union Conference at Initiating Change}

Having talked about pastors' development in the previous section, I now discuss the development of pastors from 1970s to 1990s. A number of changes in the church have taken place during this period. I will mention just a few examples where changes have taken place and how pastors and lay leaders handled the situation.

\section{Pastors' and Elders' Understanding of Initiating Change}

In the first place, there were changes in the church departments such as the Junior Missionary Volunteer became Adventist youth; Home Missionary became Lay Activities and then Personal Ministries; Church Ministries that embraced all the departments of the church; and the introduction of Children's Ministries. Church leaders handled these changes by simply introducing it without further discussion. These changes were coming from the General Conference and adopted by unions and local conferences. In the case of Zambia, church pastors would just receive memos from the local field administration. Then the church pastor and lay leader would just announce to the church.

During this period in ministry, I observed that there was not much resistance from church members. This was because church members had much respect for their pastors and lay leaders. Whatever they announced was accepted and official. It was not possible for a church member to question the pastor about the changes. I would say this was a continuation of cultural norm from the colonial mentality of saying "yes" to everything. 
This was a period of "yes" man attitude or mentality. That is why the pastors and lay leaders managed change without much resistance.

Unlike in the past, church members no longer say "yes" to everything that is presented by the pastor or lay leader. This is an age of inquiry to everything. This is no longer a period of "yes" mentality, but that of questioning. The case in point here is the handling of Women Ministries. The pastors and lay leaders handled it as any other previous departments. However, this time they could not handle the situation as in the past where leaders just announce the new changes in the church. Church members started questioning the differences between the Women Ministries and Dorcas Society. The question may be asked, "Why did it not work this time on Women Ministries?" Because church leaders used steps that did not work and these are:

1. Introduce new department through announcement during divine service.

2. Introduce new department during a large gathering.

3. Introduce new department without pastor and lay leader orientation.

4. Introduce new department without enough information.

Pastors and lay leaders should not have used these steps to introduce women ministries. Divine services and large gatherings are not good places to introduce big changes but small groups. The pastors and lay leaders should be oriented of such changes first before the rest of the church members. There must be enough information regarding the change.

Pastors and lay leaders need to have more knowledge about initiating change in their churches and districts. In this section, I discuss the pastors' and lay leaders' understanding on initiating change. Before initiating change, the leader needs to 
understand the scope of change. In addition, pastors in Zambia need more leadership training that will enable them initiate successful change. All pastors went through basic leadership training in the ministry and seminary. I have selected some areas that pastors need to emphasize when training leaders.

\section{Servant Leadership}

Church leaders in Zambia Union Conference need more leadership training. The training of leaders in the area of leadership is a very important aspect, especially those who want to successfully initiate change in their churches and districts. Moses in the Old Testament is a good example. He received training in Midian where he tended the sheep of Jethro his father-in-law (Exod 2:16-20). While Moses looked after the flock of Jethro, he saw the burning bush. God called and told him to go and liberate His people from Egypt, the land of bondage. He has now finished his forty years of leadership training while tending Jethro's flock. During this period, he learned (a) patience, (b) humility, and (c) compassion just to mention a few qualities. He spent forty years tending sheep, but this was a training that enabled him to bring a successful change to the children of Israel in Egypt. Jesus in the New Testament is another good example in the area of servant leadership. He had all the qualities of leadership.

To be successful in initiating change, pastors and lay leaders need to understand what it means to be a "servant leader." Apart from Jesus and Paul, Block (2005) adds that Moses exemplified true servant leadership when he delivered the children of Israel from slavery in Egypt to the Promised Land under God's direction (p. 260). Furthermore, Kohlenberger (2009) states that to be good change agents, it is good to start with a lesson from Jesus' servant leadership because He ushered in biblical equality without looking 
into race, cultural, age, and gender (p. 5). Block (2005) adds that a servant leader does not use his or her position or personal gain to initiate change (p. 277). Because initiating change does not require force, but patience, humility and integrity. Haffner (2005) adds that a true servant leader uses his or her eyes "to notice the needs of people" before initiating change (p. 27). Block (2005) concludes by saying that the leader must be a paradigm "of fidelity and virtue" by leading with an exemplified life (p. 278). Hence, this training is important to pastors before initiating change.

\section{Management and Marketing Strategies}

Mish (2003) defines marketing as a "process or technique of promoting, selling, and distributing a product or service" (p. 760). In order for pastors and laity to understand on initiating change, they need better strategies. Pastors and lay leaders need selling techniques of new products such as change of programs in the church. Pastors may not be managers in big companies but can learn principles and strategies of how to market the new product. In this case, the pastor learns marketing strategies that can be applied to initiating a new program in the church. This is an important aspect of reality when initiating change.

The leader needs to know and understand what strategy is best for the church. Heifetz et al. (2009) suggest that it is better first to (a) assess the situation, (b) take the best of the tradition, people identity, and history of the church and (c) incorporate them into the change situation (pp. 22, 23). In line with this strategy, it is also better to understand the culture of the church. Change can only come to the church according to culture and the prevailing situation, and this is a good strategy. 
To successfully understand how to initiate change, pastors need to take management and marketing courses. It is essential for pastors initiating change to be knowledgeable in management skills and marketing strategies and principles. Flikkema (2009) states that the leader must be skilled enough to initiate change and move along with the church (p. 11). Therefore, church members should see administrative skills in their leader.

\section{Church Growth and Change in Zambia}

\section{Structure Organization}

Neufeld (1996) states that Northern Rhodesia (now Zambia) became an organized field in 1921 and that J.V. Wilson was the first elected president at the headquarters in Lusaka. Two more mission stations were organized and these include Chimpempe from 1926-1942 and Barotseland from 1946-1958. In 1945, the headquarters moved from Lusaka to Chisekesi. In 1928, Mwami Adventist Hospital established while Yuka Hospital was established in 1955. Rusangu Secondary was established in 1960 along with coeducational boarding school. Also, Rusangu Ministerial School for pastors was established. In 1989, the Zambia Adventist Press began in Chipongwe (p. 940).

Today, if Neufeld were present, he would see how the church in Zambia is organized. Many changes have been built from 1921 to 2010. There is one union conference, two local conferences, and five mission fields. From Rusangu Secondary School, three more Adventist Secondary Schools were established. In addition, apart from Mwami and Yuka Hospitals, the Zambia Adventist Eye Hospital in Lusaka was established. Rusangu Ministerial School reorganized to create Zambia Adventist University. 
What happened in the Zambia Union Conference from 1921 to 2010 is what Anthony and Estep (2005) describe as (a) active change which is due to desired "planning and structuring, dream-driven, future-focused administration of the ministry;" and (b) passive change which is due to "administrators responding to institutional change" (p. 207). I would apply both active and passive change because the leaders had vision for the church in Zambia. They had to establish institutions like schools, clinics, and church conference headquarters in every province of Zambia. They had to develop the ministry by training the pastors as administrators at local church/district as well as to serve as administrators and departmental directors.

\section{Church Programs}

Programs also keep on changing as the need arises. In the initial organization of the Adventist church in Zambia there were only two departments run by one director. However, later as the church kept on growing, a number of departments and directors increased at both the union and local conferences. The personnel elected in the departments include both men and women.

\section{Church Statistics}

Table 2 shows church and membership growth from 1992 to 2010. During this period, the membership grew from 198,721 in 1992 to 659,336 in 2010 at Zambia Union Conference. The organized churches grew from 990 in 1992 to 2,003 in 2010. There is an increase of 460,615 members, while an increase of 1,013 churches. Luapula Zambia field is a new field that was part of North Zambia Field. This explains the blank spaces in 1992. The West Zambia Field had 281 churches in 1992 while in 2010 there were 109, 
Table 2

Zambia Union Conference Membership and Church Statistics

\begin{tabular}{lcccc}
\hline Conference/Field & M & C & M & C \\
\hline South Zambia & 51,600 & 152 & 177,328 & 375 \\
\hline Central Zambia & 43,778 & 165 & 205,488 & 614 \\
\hline Copperbelt Zambia & 50,768 & 149 & 109,009 & 412 \\
\hline North Zambia & 37,377 & 147 & 42,493 & 185 \\
\hline Luapula Zambia & - & - & 65,430 & 210 \\
\hline West Zambia & 11,035 & 281 & 44,729 & 109 \\
\hline East Zambia & 4,163 & 96 & 14,861 & 98 \\
\hline Zambia Union Totals & 198,721 & 990 & 659,336 & 2003 \\
\hline
\end{tabular}

Note. $\mathrm{M}=$ Membership; $\mathrm{C}=$ Churches. Adapted from Don F. Neufeld (1993) and obtained Zambia Union Conference local conference/field Executive Secretaries, May 23, 2011.

there is no clear explanation whether Neufeld included organized companies in his statistics. West field statistics, as the membership increases the churches should increase, but only increased by two churches, and there is no explanation to these figures. In addition, in the East Zambia Field the number of churches in 1992 was 96 and 98 in 2010, during the same period the membership in 1992 was 4,163 while in 2010 was 14,861 . To the rest of the conferences and fields as the membership grew, churches increased well. 
Demographic Information of Pastors

\section{Theological Background}

As shown in Table 3, most of the pastors in the Zambia Union have the ministerial diploma from the former Rusangu Ministerial School. This was used as a

Table 3

Zambia Union Conference Pastoral Theological Background Statistics (2010)

\begin{tabular}{lcccc}
\hline Conference/Mission & $\begin{array}{c}\text { Ministerial } \\
\text { Diploma }\end{array}$ & $\begin{array}{c}\text { Bachelor's } \\
\text { Degree }\end{array}$ & $\begin{array}{c}\text { Master's } \\
\text { Degree }\end{array}$ & $\begin{array}{c}\text { Doctoral } \\
\text { Degree }\end{array}$ \\
\hline South Zambia & 10 & 23 & 4 & 1 \\
\hline Central Zambia & 30 & 25 & 8 & 1 \\
\hline Copperbelt Zambia & 21 & 12 & 2 & 0 \\
\hline North Zambia & 6 & 3 & 2 & 1 \\
\hline Luapula Zambia & 8 & 3 & 2 & 0 \\
\hline West Zambia & 11 & 5 & 2 & 0 \\
\hline East Zambia & 6 & 6 & 1 & 0 \\
\hline Zambia Union Office & 0 & 5 & 0 & 1 \\
\hline Rusangu University & 0 & 0 & 0 & 3 \\
\hline Totals & 92 & 82 & 21 & 7 \\
\hline
\end{tabular}

Note. Obtained from Zambia Union local conferences/field Executive Secretaries May 23, 2011.

professional entry to pastoral ministry before introducing theological degrees at Rusangu University in Monze, Zambia to keep pace with the changing world.

The Zambia Union Conference has now 202 pastors (this figure includes 6 pastors at the Zambia Union as compared to Table 1 with 193) of which 92 have a ministerial diploma as their highest level of training, 82 with BA in theology, 21 with Masters in 
theology and 7 with doctoral degrees. The 92 pastors with a Ministerial Diploma have only in their curriculum pastoral work in the churches and districts. The pastors with BA to doctoral degrees obtained theological training that includes pastoral leadership.

We can see from the Table 3 that there is a good trend of training pastors in the Zambia Union Conference to meet the needs of the church in the changing world, especially in the area of leadership. There is collating between training of pastors and membership. The conferences and fields with degrees have high growth of members.

\section{Leadership and Management Training}

Kotter (1990) defines leadership as "a process that helps direct and mobilize people and/or their ideas" (p. 3). Dubrin (2004) adds to say leadership "deals with change, inspiration, motivation, and influence" (p. 4). Mish (2003) states leadership is the "capacity to lead" and is an "office or position of a leader" (p. 707). Bell (2003) states that leadership is not about a position one holds in the church structure or administration, but to practices of pastors and members as they use their spiritual gifts for the church to move forward in accomplishing its mission. I accept all these definitions for the purpose of the discussion in this section. The pastors, especially those reflected in Table 3 with a Ministerial Diploma need further training in leadership. The training can be done through refresher courses at the newly established Rusangu University for the Seventh-day Adventist Church in Zambia.

Dubrin (2004) defines management to deal "planning, organizing, directing (or leading), and controlling" (p. 4). Kotter (1990) states management involves planning, budgeting, setting goals and timetables (p. 4). Pastors need refresher courses in the area 
of management. Management training is essential for pastors who are church and district administrators at the same time doing pastoral work.

Education is very important if change is to be successful. The pastors and lay leaders need education in areas of leadership and management. Such training helps leaders to be skillful when initiating change.

As discussed in the previous chapters, the trend of change affects all aspects of life in the world and the church. Change is all about people's culture. Change transforms culture and social institutions over time. Change is inevitable because it is biblical; the world is changing, the community is changing and the church is changing. Initiate change as soon as there is a need. Formulate and implement strategies to foster meaningful change.

It is prudent in these circumstances to understand the changing world and adapt the culture of the community served. Change done in the cultural context and gradually with all strategies in place can be successful. In the Zambian culture, the leader initiating change has to (a) adopt a friendly attitude, (b) be trustworthy, and (c) adapt to the prevailing culture. The strategies must include the behavior change of church leaders and members as they do away with status quo.

The Western culture, which is spreading all over the world and demanding equal opportunities, cannot work efficiently in the Zambian culture. In the Zambian context, the leader initiating change should understand the cultural inheritance of the people. This involves the respect of the elderly people and leadership in family unit. Zambian culture is largely male dominated and patriarchal where women have less voice in the church and community, but it must be in harmony with the Word of God in dealing with culture. 
As discussed in chapter 3, the Seventh-day Adventist Church Manual has a provision to initiate change applicable to conditions and circumstances. The church in Zambia has to adopt the "adaptive leadership model" when initiating change.

\section{Statistics on Training}

Table 4 shows the need for pastors to have more in-service training in leadership and management. The figures shown in the table are seminars conducted by the Zambia Union Conference Ministerial Director at the union level for all the fields and local conferences. In the five-year period, only eight leadership trainings were conducted and only one for management. The church has a long way to go in the area of leadership and management skills. Hence, the pastors are facing resistance in initiating change. They are lacking certain skills and strategies for initiating change.

Table 4

Pastors' Leadership and Management Trainings Conducted From 2005 to 2009

\begin{tabular}{lccccc}
\hline & $\mathbf{2 0 0 5}$ & $\mathbf{2 0 0 6}$ & $\mathbf{2 0 0 7}$ & $\mathbf{2 0 0 8}$ & $\mathbf{2 0 0 9}$ \\
\hline Leadership & 1 & 3 & 1 & 2 & 1 \\
\hline Management & 0 & 0 & 1 & 0 & 0 \\
\hline Totals & 1 & 3 & 2 & 2 & 1 \\
\hline
\end{tabular}

Note. Obtained from Zambia Union Conference Ministerial Director, July 28, 2010.

\section{Conclusion}

It is important to learn from the British colonialists and the way they initiated change to the Zambian community. The colonialists and missionaries used inclusiveness 
of the local leaders in administrative duties. The missionaries also trained pastor-teachers in leadership. To effect change, they first changed the attitude of the leaders in the community. The British used chiefs as agents of change. These methods were very effective in the community.

The missionaries used schools, clinics and medical facilities to initiate change. Chiefs and village headmen became agents of change in the community. They also used the spiritual agents in preaching the message. They adapted to the situation in the community they served. People responded well especially to the social changes. The only resistance was on the role of women in the family. The man was still the head of the house and community.

Pastors and lay leaders in Zambia Union Conference need more training related to understanding of leadership and management. Pastors and lay leaders need marketing skills in initiating change. As the church grows, there is a need for new programs and strategies. 


\section{CHAPTER V}

\section{DEVELOPMENT OF INTERVENTION STRATEGIES FOR INITIATING CHANGE}

\section{Introduction}

The first section describes the workshops for pastors and elders on initiating change. This section focuses on workshops that present the principles of leadership and initiating change recorded in the Old and New Testaments. It concludes with counsel from the Spirit of Prophecy on initiating change. The second section presents workshops on spiritual and cultural steps leading to initiating change. The third section instructs the reader as to how teaching, using effective methods, can effectively initiate change.

\section{Workshops for Pastors and Elders on Initiating Change}

The previous chapter was an analysis of leadership development and growth of the church in the Zambia Union Conference. As the church grows numerically, there is also the need to initiate changes in some programs to meet the demands of the time. This will involve the training of pastors and lay leaders in workshops in Local Conference/Field Headquarters (see Appendix A), and daily schedule (see Appendix B). The material for workshops is based on combination of chapter 2, which is on theological aspects, and chapter 3 on literature available for successful initiation of change (see Appendix C). 
Principles of Leadership and Initiating Change in OT

\section{Principle 1}

Change should start with the leader himself or herself by understanding his or her strengths, weaknesses, and individual calling.

Moses from the time he led the children of Israel from Egypt until he met his father-in-law, his leadership method was that of ministering. He did all the leadership . roles by himself. However, when he met Jethro his father-in-law he made significant changes in his leadership methods. He (a) changed his way of thinking, (b) changed his way of working, (c) became a man of prayer, (d) became a good communicator, (e) became a visionary by showing the people the way to walk as they keep God's statutes, and (f) became a trainer of other leaders (Exod 18:19-21).

\section{Principle 2}

Initiate change when there is need in the church.

Moses saw the need for change when his own people were suffering from the leadership of Pharaoh. He was troubled in his mind with how to free them from this kind of slavery. He wanted to bring change from this kind of injustice and oppression. He assured the people that God would soon deliver them from injustice and oppression. $\mathrm{He}$ chose to suffer together with his own people though he was in the palace (Heb 11:24-26). Pastors and lay leaders today initiate change when there is a need for it and when the older programs are no longer needed in the church. 


\section{Principle 3}

To be successful in initiating meaningful change, the leader should be able to create a strong vision that moves the congregation in a new direction.

Woods (2001) defines vision as that guides and moves the congregation (p. 1). Such a vision should come from God because His thoughts are higher than any leader (Isa 55:9). For God knows the needs of His church. The church leader should recognize such a vision from God through "prayer, Bible study and reflection" (p. 2). This can be done through (a) seminars with Scripture reading, (b) group discussion, (c) prayer time, (d) sharing insights from prayer sessions, and (e) reflections from groups.

Apart from guiding the congregation into a new direction, the vision can protect it from the past. In the analogy of the cloud and fire in Exod 14:19, the children of Israel were protect from going back to the old and were guided to a new direction. Pastors and lay leaders should embrace this concept during the training. The leaders will be trained to make the vision simple and easily communicated.

\section{Principle 4}

Give people access to discuss the changes so that they feel connected with decision makers.

Joseph was a visionary leader, and through God's wisdom, he was able to lay down the master plan for the plenteous years and the drought years before Pharaoh and his counselors. In order to carry out this policy effectively, Joseph initiated this change by stating, White (1958) "Let Pharaoh do this, and let him appoint officers over the land" to keep food in cities in the years of plenty (p. 220). The food was to be given out in the years of drought that was to come on the land (Gen 39). White states, "for some time the 
matter of the appointment was under consideration" (p. 221). The master plan Joseph placed before Pharaoh and his counselors was under discussion (Gen 41:37-38). Nichol (1978, 1:447) adds, "Joseph's counsel was so sound and pleasing to Pharaoh and his counselors that the king proposed the appointment of Joseph as minister of food, and granted him emergency powers." This was not a simple and regional plan that was under discussion, but it involved whole land of Egypt. When Joseph accepted the responsibility of leadership, he executed his strategies. He became a leader in Egypt, and God had a purpose for him. When initiating change, the leader has to allow discussions and consultations from church members.

The church leader must be concerned with purity of the members. Change may be initiated when there is need connected with members of the church. Change goes along with a strategy that is effective for the people. The pastor and lay leader are to use table strategies and execute them for the benefit of the church. Leaders, when initiating change, should first see the need and then execute them effectively. This change must begin with the leader himself whose character is pure, active, moral, firm and reflects a clean mind.

\section{Principle 5}

Courage is the force that drives the leader into action for successful change.

Every leader, be it the pastor or lay leader, should be courageous enough to initiate change where necessary. Palmisano (2008) advises that courage is necessary despite fearing that the outcome might not succeed (p. 59). Leaders need to press on even if there are obstacles ahead. Each leader has been given a chance to be courageous. Moses and Aaron were courageous to face Pharaoh to let God's people leave slavery and 
go to the Promised Land. This principle will help the pastors and lay leaders to initiate change when there is need.

\section{Principle 6}

Leaders should be persistent when initiating change and not give up when things do not go their way.

Palmisano (2008) rightly said, "Persistence doesn't mean blind repetition when failure occurs" but gives opportunity to analyze to "see if the conclusion or approach is correct" and move on (p. 71). A good example is when Moses and Aaron continued to talk to Pharaoh to free the children of Israel; they never gave up (Exod 14:19).

\section{Principle 7}

Pastors and lay leaders need wisdom and skill when initiating change.

Such traits in leaders will help them come up with approaches to changes and gives them opportunity to learn from mistakes, which is good for leadership development. Leaders that fear are men of truth who hate covetousness (Exod 18:21). A good example is Jethros' advise to Moses—-to select men who fear God and who are full of wisdom to judge the children of Israel (Exod 18:21, 22). Joseph also advised Pharaoh to look for a leader who is "discreet and wise" to take charge of the land of Egypt (Gen 41:33). Nichol $(1978,1: 446)$ adds that not one leader is to be appointed but "a staff of officers to carry out his" advice. Pastors and lay leaders should look for men and women who are discreet and wise to spearhead the change- men and women who understand what change means to the growing organization. This portion of training will 
help the pastors especially when guiding the church nominating committee as they choose new church leaders.

\section{Principle 8}

Interpersonal relationships with church members are essential when initiating change.

To be successful in initiating change, the pastor and lay leader should be a good communicator and a good listener. Moses listened to his father-in-law Jethro on administrative issues (Exod 18). There are times when pastors and lay leaders separate themselves from being in touch with the church members because of their status. They do not want to listen to other members of the church. When the leader is separated from the members, it will be difficult to initiate change because you will not know their feelings about change.

Moses was a good listener (Exod 18:24). Reading from Deut 1:13-15, it suggests that at first Moses assumed all the leadership roles of the children of Israel because that is how it was practiced among the surrounding nations. This time, after accepting God's approved change in leading the people, Moses let the people of Israel choose leaders of their choice as long as they met the criteria of judging (Exod 18:25). Jethro's method of leadership helped Moses because it relieved him of his heavy responsibilities that were upon him. This was also good for better leadership in the camp because it brought a perfect order. Before the change, it was chaos when dealing with day-to-day cases. This change was necessary for Moses to allow the people to exercise democracy. Change was necessary at that time. There are times when changing leadership style is necessary to replace the old system. 


\section{Principle 9}

The leader initiating change should have integrity.

Joseph's integrity was displayed as he met his brothers who came and humbly bowed down before him. Instead of using his authority as a high-ranking officer in Egypt to retaliate against his brothers, he said "You meant evil against me, but God meant it for good, in order to bring it about as it is this day, to save many people alive" (Gen 50:20). It was only his integrity that landed him in a high position in Egypt and kept him from carrying out vengeance against his brothers.

In many instances, I have seen a number of pastors and lay leaders holding grudges against fellow pastors and parishioners. In such circumstances, it will be difficult to initiate change. Like Joseph, the leaders need to spend time in God's characterbuilding training. When resistance to change comes, that is the time when the leader's character is truly revealed. When leaders choose to develop their characters in God's perspective, they become much stronger. Pastors and lay leaders need to understand and live by this principle of God's character building.

\section{Principle 10}

The leader initiating change should be able to size up a situation.

When Jethro arrived at the camp of Moses and saw his leadership style, he immediately reacted (Exod 18:13-18). He concluded in his mind that there was a leadership problem in the camp that needed to be changed immediately. In this situation, any leader in any organization needs to size up the situation and act immediately for a change. The leader need not wait for the church board or church business meeting to have 
a discussion, but the leader's intuition should dictate if change is needed and if it will benefit the congregation.

\section{Principle 11}

The leader initiating change should follow the trends in the church and the community.

Jethro as he visited Moses in the camp could read the trends and could see where his son-in-law was heading with his leadership. He could easily see that his son-in-law was heading towards trouble. He then told Moses "Both you and these people who are with you will surely wear yourselves out. For this thing is too much for you; you are not able to perform it by yourself" (Exod 18:18). Jethro could tell beyond a doubt that Moses was heading into a disaster if he did not change.

The leader initiating change should ask himself/herself such questions as:

1. What programs are other churches doing that we are not doing?

2. Why are we lagging behind our sister churches in church programs?

3. Why is our church still doing things in the old way?

4. The world is fast changing; so is the community where the church is located, but our church is still doing things the old way. Why?

If the leader does not take initiative of change, the church is then heading into isolation from other sister churches and lagging in church growth. As the membership grows, there is need of change to meet the needs of the congregation.

\section{Principle 12}

The leader initiating change spends some time in prayer relationship with God. 
God was with Joseph even in the foreign land of Egypt (Gen 39:2, 21; 41:45).

Nichol (1978) states that God was always at his side to prosper and bless him (p. 439). Haynes (1962) comments that after listening to stories about his grandfather Isaac and his father Jacob, God became very real to him. He had the knowledge of God, and what He "had done in the history of his family" (p. 21).

From his early life, he had a vital relationship with God. This means that on his own he could do nothing. He relied upon God for wisdom and knowledge. Blackaby and King (1998) state that he could only achieve this through his relationship with His God and by being obedient to Him (p. 80). God wants his leaders to (a) prosper, (b) find favor in the eyes of the people, and (c) have success.

\section{Principle 13}

The leader initiating change should be able to empower other leaders.

Moses, after being empowered by his father-in-law Jethro, empowered other leaders who were chosen. Instead of doing all the judgments in the camp alone, he now assigned new responsibilities to appointed leaders (Exod 18:21, 22). Gangel (2000) suggests that "no one person can accomplish the task alone" unless he or she does it with other leaders who are entrusted to do it. In other words, "sharing responsibility and authority with other people" (p. 111). When initiating change in the church, it is important to train other leaders and share the change so that they in turn are given authority to speak on your behalf. Give them the necessary tools to implement the change with less supervision. In this case, when you empower other leaders it means you have confidence in them to do the work. Pastors and lay leaders need to be trained in this area as well. 


\section{Principles of Leadership and Initiating Change in NT}

\section{Principle 1}

The leader initiating a successful change must establish a common ground.

In conversation with the Samaritan woman, Jesus being thirsty and hungry, asked for a favor (John 4:7,8). Therefore, water was a good connection because it was a common interest between Him and the woman. Leaders initiating change should ask: What is the common ground between the change I am initiating and the members? Once this is established, it becomes easy to begin the process of change.

\section{Principle 2}

The leader initiating a successful change must initiate the contact with other leaders in the church.

When Jesus was with the Samaritan woman at the well, He initiated the contact by asking her for a drink (John 4:7). From that moment, the discussion started that led to a big spiritual change in her life and not only her, but also the people of the city believed in Jesus (John 4:39-42). In this principle, leaders initiate the contact that changes the life of an individual, and they in turn, change the lives of others too!

\section{Principle 3}

The leader initiating a successful change must stick to one issue at a time.

Jesus in the discussion with the Samaritan woman at the well did not allow any distraction or divert from the real issue, nor did He allow her to divert from the real issue at hand (John 4:20-24). The key issue here was not on cultural differences between Jews and Samaritans, but on accepting Jesus as the Messiah. 


\section{Principle 4}

The leader initiating a successful change must be a good communicator on that particular change.

In the conversation between Jesus and the Samaritan woman, Jesus made it clear to her that He was the Messiah (John 4:25, 26). Before He revealed His identity to the woman, Jesus explained about Himself from water to worship in a clear manner. This led her to ask about the Messiah to come. Leaders initiating change learn from this principle of being good communicators by simplifying the process of change. In addition, leaders will ask how the members will benefit from this change. The leaders must be able to sell their agenda for change through better communication.

\section{Principle 5}

The leader initiating a successful change must be receptive to people with different temperaments.

Jesus in the conversation with the Samaritan woman at the well knew what kind of a woman she was in the community. After establishing who she was, Jesus did not rebuke or condemn her sinful activities in the community (John $4: 17,18$ ). This principle teaches leaders to embrace every other leader of the church by understanding and knowing their temperaments. Engage every leader into a meaningful discussion on change by accepting whom they are and by acting the way they act.

\section{Principle 6}

The leader initiating a successful change needs to be empowered to empower others. 
This principle is almost similar to that of principle 13 in the Old Testament principles above. The only difference is that the leader must first be empowered before empowering others. The empowerment here is when the leader is filled with the Holy Spirit (Acts 4:8; 9:17; 13:9).

\section{Principle 7}

The leader initiating successful change must expand the horizon of ministry and help other leaders to think outside the box.

Church leaders, and especially old members in the church who want to maintain their status quo, must first be convicted of the change and then be able to help other leaders to accept new ideas. A good example is when Peter accepted a new vision that expanded his horizon of ministry to Gentiles like Cornelius a Roman centurion (Acts 10:9-16).

\section{Principle 8}

The leader initiating a successful change must develop the skill of persuasion.

Peter before the Jerusalem council saw the need for change among the Jewish leaders. He suggested a big change in the way the church was doing things regarding the conversion of the Gentiles. In the discussion at this council, Peter aimed at shifting the thinking and belief of the Jews toward Gentile converts. He finally persuaded the council leaders of God's mission to the Gentiles (Acts 15:7-11). Training leaders by using this principle will help them achieve a successful change in the church. 


\section{Principle 9}

The leader initiating a successful change must exercise a positive influence on other church leaders.

When there is an urgent need for change in the church, the leader initiating that change must exercise a positive influence on other church leaders. In this influence, the initiator must show cause of change in a positive manner. Leaders must learn a lesson from the positive influence of Barnabas, Paul and James, who was the chair of the Jerusalem Council (Acts 15:12-29).

\section{Spirit of Prophecy Counsel on Initiating Change}

\section{Counsel 1}

Believe in the prophetic counsel to change.

Ellen G. White (1983) gave counsel to the church regarding the publishing work at Battle Creek and how it needed to be moved to other places. She counseled the church leaders that "when the Lord tells us to move, we are to obey, however inconvenient and inconsistent such a command may seem to us to be" (p. 182). The pastors and lay leaders in Zambia Union Conference need to be educated through workshops and seminars about this counsel when initiating a successful change.

\section{Counsel 2}

Change leaders for better administration.

There are times when some leaders do not function as expected, and they take wrong direction in administration. In these cases, a change of leaders may be needed. Hence, Ellen G. White (1983) counseled the church that in institutions that lose direction 
of leadership in accordance to the Word of God, a change of responsibility is needed. It is important to put with firm principles mingled with love in place, so they can conduct God's work in rightful manner. In other words, a reorganization of leadership is needed (pp. 142,143).

\section{Counsel 3}

Change needed to advance the gospel.

Ellen G. White (1896) counseled church leaders against making wrong decisions, methods, and carrying out "plans which are not of the Lord's devising" in evangelism (Letter 81). This is what is needed of pastors and lay leaders regarding evangelism. Many decisions, methods, and plans are devised, but they are not in accordance to God's plans. Therefore, a change of course in evangelism is needed. The emphasis should not be on promoting our own goals and offerings.

\section{Counsel 4}

Change to advance unity.

Ellen G. White (1962) counseled the leaders to have a form of church organization to avoid great confusion. The change was not easy at this time; most Seventh-day Adventists opposed such organization and had an upper hand during debates on such counsel. Finally, the opposition was wrong and the advocates for change prevailed through prayer and light given by the Holy Spirit that "organization was essential" (p. 26). There are times when the members are disorganized. In such cases, the leaders need to be in harmony with members in all the areas of church development. 


\section{Counsel 5}

Change is important when the community changes.

Ellen G. White (1948) gives counsel to church leaders to be careful when initiating change as the community changes. She counsels that when the community. changes, especially in the dress code, the church must be cautious not to be first or last but strike the balance, which is modestly in God's design (pp. 424-426).

\section{Spiritual and Cultural Steps Leading to Initiating Change}

The Spiritual Steps Leading to Initiating Change

Pastors and lay leaders need to take spiritual steps in their leadership roles. These steps include (a) spiritual formation, (b) developing arenas of movements in spiritual formation, and (c) communion with the Holy Spirit through prayer.

\section{Step 1: Emphasize Spiritual Formation}

\section{for the Leader}

The strategy to initiate change begins with the leader and his or her attitude towards the members. Herrington et al. (2000) state that the leader must first have (a) personal spiritual formation, (b) capabilities to initiate change, and (c) find the right time to initiate change in the church (pp. 32,33). To be successful in initiating change, the leader must (a) change his/her own thinking process, (b) remove fear, and (c) have ability to come up with a meaningful strategic plan of attack. Also the leader must have a positive attitude to change before it is initiated to the church. 
The experience of the Gospel

The pastors and lay leaders need to know and experience what it means to be a child of God. They need to have faith in God that He will guide them in what they want to change. Their hope in the Lord should not be diminished because of resistance they will experience when initiating change. It is imperative for leaders to love God supremely with all their mind, soul, and strength. For the leaders to experience the Gospel, they need to live a life of faith, hope, and love in God. Then the change initiated will be successful. In other words, experiencing the Gospel is the whole being of the leader.

The kingdom living

The pastors and lay leaders in spiritual formation need to be practical in their living as children of God. They need to be doers of the Word they present to the church members. Above all, the leaders initiating change in the church need to behave as children of God. They are representatives of the kingdom of God here on earth. In actual fact, the leaders need to live a representatives live, with values and ideals of the kingdom of God and also of the Seventh-day Adventist Church in Zambia. They should be good examples to the church members, and those in the community. They should show obedience to God and others in the church.

The pastors and lay leaders must feel the presence of God. They must seek God's face always in their ministry as church leaders. They must have confidence that God is always with them as they initiate change in the church. They must have courage to move on despite resistance from those with opposing views. They must be assured that they have God on their side and a faithful Friend in times of leadership hardships. 
The pastors and lay leaders should seek the presence of the Holy Spirit. Not only should they seek the presence of the Holy Spirit, but they need to walk in the Spirit always. It is important for the church leaders to allow the Spirit to guide them in their visions for the church. They should always respond to the promptings of the Holy Spirit. They should receive the (a) comfort, (b) guidance, (c) correction, and (d) power of the Holy Spirit.

\section{Step 2: Develop Three Arenas of Movements in Spiritual Formation}

The relationship with God

The pastor and lay leader need to experience a movement toward God in spiritual formation. There must be a strong relationship to God. The leader should have that compiling desire to live a holy life. The leader initiating change should have a vision of Jesus. This relationship should compel the pastor and lay leader to have a desire for the presence of God. Furthermore, this relationship should compel the leader to accept suffering when encountering resistance to change. The leaders should also understand that the ordinary events of life should be turned into opportunities for spiritual growth.

The relationship to self

During spiritual formation, the leader initiating change should examine oneself. The leader should know his or her strengths and weaknesses. The leader needs to discover his or her strengths and the areas of achievements, and then be evaluated by other leaders in the church. The leader needs to know his or her weaknesses, and this can be assessed by fellow leaders through some failures in some programs of the church. All this can be done through a questionnaire sent to other leaders of the church departments. 
The relationship to others

Pastors and lay leaders initiating change should have good relationship with others in the church. In addition, they need to have a good relationship to those outside the church. There must be good relationships with the departmental leaders of the church that including the Adventist Youth leader, Pathfinder leader, Dorcas leader, Adventist Men's Organization leader (AMO), Sabbath School leader, Personal Ministries leader, Head deacon and deaconess leaders, and other leaders in the church. These leaders are potential agents to change in the church and should not be ignored.

\section{Step 3: Develop the Breath of the Holy Spirit-Prayer}

During the spiritual formation, the pastor and lay leader should ask the following questions:

1. Am I taking my vision for the church to God in prayer and surrendering my life to Him each day?

2. Am I spending sufficient time talking to God each day?

3. Am I spending enough time praying for the opponents of change in the church? Read from these verses: John 15:7, 16;16:23.

\section{The Cultural Steps Leading to Initiating Change}

The pastor and lay leader initiating change must follow cultural steps. These steps help when leading old established congregations. Some of these churches are rooted in traditions, maintaining a status quo. 


\section{Step 1: Consider the Cultural Practices of Each Church}

The pastors and lay leaders in these workshops and seminars need to know the definition of culture. Culture is the understanding of peoples' values, beliefs, rules, symbols, traditions, attitudes and norms that knit a community together. In other words, it is a "way of life," or a way people live in the community. Sometimes culture is defined as a means of adapting to situations in the community.

In addition, church culture is defined as a way of how we do things at this church. This understanding has become a negative experience for leaders when initiating change. Most of the rural churches in Zambia Union Conference are rooted in culture or tradition and have a long history of Christian faith to resist change. Tradition is taken to be an important issue in the church, and members are not used to change.

\section{Step 2: Consider the Culture of the Community}

The pastors and lay leaders need to know the culture of the community. The leader initiating change must (a) understand the culture of the community, (b) know the needs of the people, (c) know the values and religion, and (d) then develop a meaningful strategy which is contextualized to the local situation. The leaders need to (a) know the meaning of words as they are used in that culture; (b) know the content and context of the message bearing in mind of the high- and low-context cultures; and (c) identify themselves with members in the setting of their culture.

The pastors and lay leaders need to learn from Jesus Christ because He fit well into all cultures of His time. Hence, He met and discussed spiritual things with the Samaritan woman. To this regard, today, pastors and lay leaders according to Elmer 
(2006) need "to learn how to express Him in the local context." They need to portray a Christ who will look "more Zambian among the Zambians." Elmer cautions the leaders initiating change so that, though they may fit in local culture, they need to be "careful not to mistake our own culture values with biblical truth" (pp. 109, 110). Always Scriptural truth prevails. These are some of the issues pastors and lay leaders should know. This is a very important issue in Zambia when it comes to cultural changes in the church. The training should be helpful to the church leaders.

\section{Step 3: Understand and Know the Elderly People in the Church}

The pastors and lay leaders need to be taught on how to handle the elderly members in the church. These elderly members have deep cultural backgrounds and a long history in the church. They have the capital to trigger an explosion of resistance if not handled properly. It is important to give respect to the elderly people in the church, because in the Zambian context, advanced age is equivalent to wisdom. In other words, the older one gets, the wiser one becomes. The pastors and lay leaders need to know that these elderly people in the family, the clan, the whole village value them as their leaders, and their counsel is followed. They are given top priority in every social activity in the community and in the church too. The family, clan, village structure is very important in the church when leaders are initiating change, because when the elder is converted, it means converting the whole family or clan.

In the seminars and workshops, the pastors and lay leaders need to be reminded of the Zambian culture as a strong social unit based on extended family, which is linked to a larger society of the same clan. These social units should not be ignored in the church 
when initiating change. It is much easier to communicate and explain the changes in the church to the head of the family than to everyone in the family.

\section{Step 4: Apply the Joseph Model}

The churches in Zambia are multicultural based on different tribal groups with different cultural backgrounds. The pastors and lay leaders should learn a lesson from Joseph who lived cross-culturally. According to Elmer (2006), Joseph maintained the Hebrew culture believing in the Lord God and that of the Egyptians. He embraced the Egyptian culture, but then continued revealing the presence of the Lord through his conduct. He also learned how they communicated, but he did more by giving respect to those he came into contact with. "Like Joseph, we need to d

.00 what the local people do and fit in as much as possible without violating our faith" (p. 195).

\section{Teach Effective Methods for Initiating Change}

\section{Method 1: Use Old Guard Method}

This method means that pastors and lay leaders initiating change need to make use of elderly people in the church. These elderly people should not be sidelined in the process of initiating change. To be more specific, elderly people are those who have been in the church for a long time, probably from the time the church was organized as a company of believers. In other words, they are the nucleus of the church and need to be identified.

Why then should the pastors and lay leaders use this method when initiating change? It is because the elderly, or the old guards, are influential and their voice is heard 
more than any other member of the church. As a matter of fact, in the Zambia Union Conference, this method is more practical in the rural churches than urban areas. The rural churches are where you find elderly members in the church. This method helped Moses and Aaron to deliver the message of deliverance to the children of Israel. This was to be a change of direction for the children of Israel. They used this method by first meeting "all the elders of the children of Israel" (Exod 4:29). Therefore, it is imperative for the pastors and elders initiating change, whether in rural or urban churches, to know and understand this method.

\section{Method 2: Use Adaptive Change Method}

In order for pastors and lay leaders to be successful in initiating change, they need to use the adaptive change method. This method implies that when initiating change the leader, as pointed out by Heifetz et al. (2009), should "build on the past rather than jettison" (p. 15). In other words, when initiating change using this method, leaders should not get rid of or throw away the old system or program completely. Furthermore, the leaders initiating change should involve the church members so that they will be able to distinguish what is important in order to preserve their long cherished heritage. Also, what is to be noted in thị method is that it is "both conservative and progressive" (p. 15).

Paul and Peter used this method at the Jerusalem Council when they addressed the elders of the church regarding the Gentile converts. They convinced the leaders who were gathered at this council to adapt to change as the situation dictated. The situation of the Gentile Christians was different from that of the Jewish Christians when it came to traditions. In their discussions, a change was initiated by Peter to accept Gentile Christians as they found the message. This was a paradigm shift in their belief, though 
the condition was given to the Gentile Christians to do away with traditions that contradict the gospel (Acts 15:7-11).

There is a provision for adaptive change in the Seventh-day Adventist Church Manual (2005) that stipulates that each division can modify recommendations given by the General Conference of the Seventh-day Adventist Church according to local conditions and circumstances prevailing. Once this modification is made, it has to be endorsed by the General Conference Committee before it is implemented (p. xxi).

\section{Method 3: Use Marketing Method}

The pastors and lay leaders need to know and understand a few marketing principles. Whenever change is initiated in the church, some of the marketing methods are to be used. The leaders need to know the right marketing method for that particular church or district. In this marketing method, the leaders are not restricted to one medium of advertising their new product, which is the new program initiated.

What are some of the marketing ideas that can be used in advertising the new product? The leader has to survey the environment before initiating the change. The leader needs to choose the best method of communication that will help the people to understand and accept the product. The leader chooses the best strategies to market his or her new product to the people.

\section{Method 4: Have an Inner-Circle}

In these workshops and seminars, the pastors and lay leaders need to know and understand the following inner-circle method Moses used when he met the elders (Exod 3:16): 
1. Moses meets Aaron (Exod 4:28).

2. Moses and Aaron meet the elders (Exod 4:29).

3. Moses and Aaron and the elders meet the people (Exod 4:31).

Moses and Aaron gathered the elders and told them the time for change had come, and they accepted the message (Exod 4:29-31). As Moses and Aaron met with elders, so it is with leaders initiating change to include and educate the inner circle of church elders and church board.

\section{Conclusion}

Change should start with the leader by gaining an understanding his or her strengths, weaknesses, and individual calling. To be successful in initiating meaningful change, the leader should be able to create a strong vision that moves the congregation in a new direction. The leader initiating a successful change must develop the skill of persuasion, and must exercise a positive influence on other church leaders.

The pastors and lay leaders initiating change should adhere to the Spirit of Prophecy counsel. There is spiritual danger for ignoring the Spirit of Prophecy when initiating change. The spiritual formation is a necessity for pastors and lay leaders. Spiritual formation involves the total being of a leader as a child of God. In addition, the leader needs to live a life that represents the life, values and ideals of the kingdom of God. The leader initiating change should be to adhere to leadership principles and counsels for successful change. 
CHAPTER VI

\section{SUMMARY, CONCLUSION, AND RECOMMENDATIONS}

\section{Summary}

Chapter 2 basically discussed theological foundations on initiating a successful change that was based on the Old and New Testaments and on the writings of Ellen G. White. It should be noted that change is biblical. The Bible is full of characters that initiated change as the environment dictated both in the Old and New Testaments. The discussions in this chapter focused on the lives and ministries of Joseph, Moses, Jesus, Peter and Paul.

\section{Essential Change Elements}

\section{Integrity}

As learned from the life of Joseph, integrity is important for leaders who are eager to initiate change in the church. Pastors' and lay leaders' integrity should earn them a good reputation within and outside the church. They should be noble leaders who can be trusted by church members. This can only be achieved by being faithful and doing God's will. It must also be understood that God shapes the leader's character in order to be strong in the course of the initiation of change.

As it was learned from the ministries of Joseph, Moses, Jesus, Peter, and Paul, pastors and lay leaders today serve as God's changing argents in the lives of people and 
church programs. At its conference sessions, the Seventh-day Adventist Church World Headquarters in Washington, DC introduces changes in its operations. The pastors and lay leaders should be agents of these changes in their local churches and conferences.

\section{Leadership Credibility}

Pastors and lay leaders initiating change must show qualities of leadership to be credible. They must possess administrative skills that go along with strategies to execute change in the church.

\section{Listening to the Members}

The leader initiating change should listen to church members and to the Holy Spirit as he speaks to members too. Leaders do not have a monopoly on the Holy Spirit. Listening to members on issues related to change is very important to the pastor and lay leader. Listening also helps the leader to be able to synthesize information as it comes from the members. The leader must listen to other people's counsel and talk less. Pastors and lay leaders should put into consideration that God should be the driving force for success with every change that is initiated.

\section{Clear Communication}

When initiating change the leader must communicate the change clearly to the members. The interpretation of the change and strategies must be very clear to those that are going to implement them. Communication is very important when initiating change. The leader must sell the changes initiated to the members of all age groups, and let them discuss and submit ideas where necessary. 
Poor communication cannot make successful change. Communication is an important aspect in initiating change. The leader must (a) move around and talk to the church members, (b) listen to their concerns on change, (c) establish more relationships, and (d) give more information on change by making it available to every age group of the church. The leader must be able to translate the change in a simplified manner by giving out the (a) purpose, (b) strategy, and (c) time frame.

\section{Absence of Coercion}

When initiating change in the church, the leader must not use force get the people to accept that change (Exod 2:11, 12). The leader must obtain the consensus of the church members-first from the board of elders and then from the church board or business meeting. People and the leader must agree to that change. It should not just be imposed on them.

\section{Inclusiveness of Process}

It is wise for the leader initiating change to seek assistance from the inner circle of close supporters who share the vision and can point out some weaknesses. The inner circle must include individuals of different spiritual gifts. Also, the inner circle must share the same vision as that of the leader. Leadership is not a one-man army, but it is through working with others who are more experienced and Spirit led. In this way the leader learns from others' wisdom and skills on how to initiate change in the church.

Leaders initiating change must be able to listen and allow others to speak as well (John 4:9). The most important thing is to accept church members where they are as Jesus did with the Samaritan woman (John 4:17-18). When initiating change, it is better to stick 
to the issue of concern (John 4:20-24). These issues must be communicated directly to the church in simplified a manner (John 4:25-26).

\section{Cultural Sensitivity}

As a leader, when initiating change, one needs to understand the culture of the people in the way they have been doing things. Peter as God's agent of change broke down the cultural barrier. The leader has to understand and adapt to the culture of that particular church. It is prudent also to learn and understand the culture of the people to change their behavior. This can be done through having direct contact with individual elders of the church and the community (John 4:1-7). In addition, it is better to look for the common ground with church members as change is initiated (John 4:7-8).

Most churches that are rooted in culture or tradition and have a long history of Christian faith resist change. Tradition is an important issue in the church and members are not used to change; they do not even dream about change. This is especially true of the old members who have a (a) deep cultural background, (b) a long history in the church, and (c) they have the capital to trigger an explosion of resistance. In order for the leader to overcome social and cultural barriers, it is necessary to learn new ways of thinking and behaving. The leader can achieve this (a) by knowing the meaning of words that are used in that culture, and (b) by identifying with church members in their cultural setting.

\section{Anticipation of Resistance}

Whenever there is change, there are those who resist such changes. As evidenced in the Jerusalem Council, Paul and Barnabas experienced opposition to the changes that 
came into the spiritual lives of Gentiles. Even today, pastors and lay leaders should be prepared for any opposition to changes that might be initiated. Pastors and lay leaders experience similar controversies whenever there is a change of programs in any department of the church. Not every elder in the church will accept change initiated by the church pastor and conference leaders. There will be those who will oppose and come up with their own plans and ideas to confuse the church. They would want to impose their plans and ideas on believers. This is where lessons can be learned from the Jerusalem Council: Whenever there is change in any organization, resistance from some prominent pastor is inevitable. Even some pastors are found on the side of the opposition transition party.

\section{Leadership Influence}

There are times when leaders can use the power of influence when initiating change in the church. A good example is the influence from the council in Jerusalem. The decision of the Jerusalem council gave freedom to the Gentile Christians from the bondage of the Jewish ceremonial laws. The council made the burden light by exercising their influence and changed the direction of the church. The decision was a positive influence that would be emulated throughout generations to come.

Change is necessary if it builds the unity and progress of the church. On the other hand, change may bring the church out of harmony with the principles of the Word of God. The leader may give freedom of choice to the church for any change they want, but they need to be warned about the effects of these changes upon their spiritual growth. Therefore, it is important for the church leader to initiate change that will enhance unity in the church. 


\section{The Process of Change}

Chapter 3 discusses literature that can be used when initiating change in the church. Many writers have written much on the definition of change. One of them is Macionis (2007). From his sociological perspective, he defines change to mean "the transformation of culture and social institutions over time" (p. 483). From the Christian point of view, everything that is known as Christian means change, such as in John 3:5 (new birth), and 2 Cor 5:17 (new creatures). It is known that change is a central aspect of the Christian experience. Therefore, change is not just initiated because it is biblical, but because the community and world we live in is changing as well.

As the community changes, the leader must be prepared for changes in the church. Change is good for the spiritual life of the church members, and the leader must read the times in which we live in and respond to changes that come about in the community. The world we live in does not stand still; thus, the life of the church is dynamic, and it is always in motion. Churches need to grow. Otherwise, they will be using outdated programs and methods that make young people leave the church. The Seventh-day Adventist Church in Zambia cannot simply ignore change, and church leaders must initiate that change.

\section{Adaptive Change}

Leaders can use adaptive change methods because it focuses on changing the people's beliefs and habits. In this method, it is important that church members move along with the leader when initiating change. It is important to break those old mind-sets, or change the present behavior patterns. It is, therefore, imperative that the leader be able 
to understand the behaviors of the church members in their social and cultural context because this is the key to the success of change.

The leader initiating change must (a) assess the situation, (b) take the best of the tradition, people identity, values, beliefs, and history of the church, and (c) incorporate them into the change situation. Furthermore, (a) engage the church members, (b) find out major values, and (c) see if there will be any support by serving such values. The hardest part for a leader is to bring ideas from the world or community and make them useful realities of the church. It is not always about following changes that take place outside the church, but to always think in terms of church growth and develop better strategies.

\section{Engaging Others}

One of the goals of the leader initiating change should be to think of decision makers who have the art of influencing others and are familiar with the proposal for change. These people are in the churches and can be used for God's work. On one hand, it is better to identify potential opponents who think they will lose something if the change succeeds and (a) stay close to them, (b) love them and (c) spend time with them explaining the need for change and how painful it will be. Such an approach of humility to those that oppose the change makes your supporters have positive feelings about their leader and his or her initiative for change. On the other hand, it is good for the leader initiating change to work with the elderly people in advance of the change. Once these people are fully engaged, they can be changing agents in the church. 


\section{Demonstrating Change}

The leader must first have (a) personal spiritual formation, (b) capabilities to initiate change, and (c) find the right time to initiate change in the church. To be successful in initiating change, the leader must first (a) change his/her own thinking process, (b) remove fear, (c) have the ability to come up with a meaningful strategic plan of attack, and (d) have a positive attitude to change before it is initiated in the church.

\section{Training for Change Competence}

Chapter 4 focuses on the training of church leaders as an important tool that can be used for successful initiation of change in churches and districts. Training can be through workshops or seminary for pastors. Training in management and marketing skills are essential tools when initiating change in the church.

To be successful in initiating change, pastors and lay leaders need to understand what it means to be a servant leader. To be good change agents, it is good to start with a lesson from Jesus' servant leadership, because He ushered in biblical equality without looking into race, cultural, age, and gender. Most importantly, a servant leader does not use his or her position for personal gain to initiate change. A true servant leader uses his or her eyes to see the needs of church members before initiating change and then use better strategies.

Chapter 5 discusses the development of intervention strategies for initiating change. Pastors and lay leaders need to know and understand the principles of leadership and initiate change as recorded in the Old and New Testaments. It is equally important for pastors and lay leaders to take heed from the Spirit of Prophecy counsels on initiating change. Furthermore, workshops should be conducted for pastors and lay leaders on 
spiritual and cultural steps leading to initiating change. Finally, the most successful way to initiate change is through teaching and using effective methods.

\section{Conclusion}

The trend of change affects all aspects of life in the world and the church. Change is all about people's culture. Change transforms culture and social institutions over time. Change is inevitable because it is (a) biblical, (b) the world is changing, (c) the community is changing and (d) the church is changing. Change can be initiated as soon as there is a need. Strategies to foster meaningful change have to be formulated and implemented.

It is prudent in these circumstances to understand the changing world and adapting the culture of the community served. Any meaningful change must be done gradually in the cultural context and with all strategies in place. In the Zambian culture, the leader initiating change has to (a) adopt a friendly attitude, (b) be trustworthy, and (c) adapt to the prevailing culture. The strategies must include the behavior change of church leaders and members as they do away with status quo.

The Western culture, which is spreading all over the world and demands equality of opportunity, cannot work efficiently in the Zambian culture. Any meaningful change in the Zambian church must be in the Zambian cultural context. The leaders must (a) respect the elderly people and their cultural inheritance; (b) understand the family as a social unit; (c) respect the husband's authority in making decisions; (d) understand that the Zambian culture is largely male dominated and patriarchal where women have less voice in the church and community; (e) make sure changes are in harmony with the Word 
of God when dealing with culture. The Seventh-day Adventist Church Manual has a provision to initiate change applicable to conditions and circumstances.

\section{Recommendations}

\section{Zambia Union Conference}

1. I recommend that the Zambia Union Conference administrators should take a leading role by calling all the seven field and local conference administrators to educate them on new changes in the organization.

2. I recommend that the Ministerial Department set aside a budget to assist the seven local conferences and mission fields for the purpose of conducting denominational workers' meetings to educate them on new changes in programs.

3. I recommend that immediately after the Seventh-day Adventist General Conference Session, when major decisions and changes are made, to immediately call for Union Conference Administrative Council to strategize the implementation of such changes.

\section{Rusangu University}

1. I recommend that a curriculum be developed that includes pastoral leadership, management, and marketing courses for pastors. These are to be core courses and not electives.

2. I recommend that a curriculum be developed for in-service training for pastors and elders according to local conferences and mission fields during school breaks. The training should focus on leadership, management and administrative. 


\section{Local Conferences/Mission Fields}

1. I recommend that the Ministerial Director set aside a budget for denominational workers' meetings to train and educate pastors on new changes from the Union and Local Conference.

2. I recommend that the Ministerial Director assist church and district pastors in training local lay leaders.

\section{Local Churches}

1. I recommend that church and district pastors call the elders' board at local and district level for training when effecting changes in church programs from the Union and Local Conferences.

2. I recommend that church elders, with assistance of the pastors, should call the church board and educate the members on changes that have been initiated by the leaders. 
APPENDIX A

WORKERS MEETINGS IN LOCAL CONFERENCE/FIELD HEADQUARTERS 


\section{WORKERS MEETINGS IN LOCAL CONFERENCE/FIELD HEADQUARTERS}

Local Conference/Field

1. East Zambia Field

2. Luapula Zambia Field

3. North Zambia Field

4. Copperbelt Zambia Field

5. West Zambia Field

6. South Zambia Conference

7. Central Zambia Conference
Centers for the meetings

Chipata

Kasama

Mansa

Ndola

Mongu

Monze

Kabwe

These centers are good for the pastors as they come for workers' meetings. These meetings are conducted twice a year-once in January and once in July. In January, they receive new programs from the office departmental leaders for churches and this is the right time to launch new programs and train the pastors. In July, progress of the work and programs that were initiated at the beginning of the year are evaluated. 
APPENDIX B

DAILY SEMINAR TIME TABLE 
DAILY SEMINAR TIME TABLE (Thursday-Sunday)

\begin{tabular}{|c|c|c|}
\hline Day & Time & Lecture \\
\hline \multirow[t]{4}{*}{ Wednesday } & $5: 00 \mathrm{pm}-6: 00 \mathrm{pm}$ & Leadership \\
\hline & $6: 00 \mathrm{pm}-7: 00 \mathrm{pm}$ & Supper \\
\hline & $7: 00 \mathrm{pm}-8: 00 \mathrm{pm}$ & Vision \\
\hline & $8: 00 \mathrm{pm}-8: 30 \mathrm{pm}$ & Devotion \\
\hline \multirow[t]{7}{*}{ Thursday } & 6:30am - 7:00am & Devotion \\
\hline & $7: 00 \mathrm{am}-12: 00 \mathrm{pm}$ & Lectures \\
\hline & $12: 00 \mathrm{pm}-1: 00 \mathrm{pm}$ & Lunch Break \\
\hline & $1: 00 \mathrm{pm}-6: 00 \mathrm{pm}$ & Lectures \\
\hline & $6: 00 \mathrm{pm}-7: 00 \mathrm{pm}$ & Supper \\
\hline & $7: 00 \mathrm{pm}-8: 00 \mathrm{pm}$ & Lecture \\
\hline & $8: 00 \mathrm{pm}-8: 30 \mathrm{pm}$ & Devotion \\
\hline \multirow[t]{3}{*}{ Friday } & 6:30am - 7:00am & Devotion \\
\hline & 7:00am - 12:00pm & Lectures \\
\hline & 1:00pm - 6:00pm & Lectures \\
\hline Saturday & $2: 00 \mathrm{pm}-6: 00 \mathrm{pm}$ & Lectures \\
\hline \multirow[t]{4}{*}{ Sunday } & 6:30am - 7:00am & Devotion \\
\hline & $7: 00 \mathrm{am}-12: 00 \mathrm{pm}$ & Lectures \\
\hline & $12: 00 \mathrm{pm}-1: 00 \mathrm{pm}$ & Lunch Break \\
\hline & $1: 00 \mathrm{am}-6: 00 \mathrm{pm}$ & Lectures \\
\hline Monday & 6:30am - 7:00am & Devotion/Departure \\
\hline
\end{tabular}


APPENDIX C

TOOLS TO BE USED DURING THE SEMINARS AND WORKSHOPS 
1. Blackaby, Henry T. and Claude V, King. (1998). Experiencing God. Nashville: Broadman and Holman.

2. Cymbala, Jim. (2003). Fresh Wind, Fresh Fire. Grand Rapids: Zondervan.

3. Elmer, Duane. (2006). Cross-cultural servanthood: Serving the world in Christlike humility. Downers Grove: Intervarsity Press.

4. Cosgrove, C. H., \& Harfield, D.D. (1994). Church conflict: The hidden system behind the fights. Nashville: Abingdon.

5. Bell, S. (2003). A time to serve: Church leadership for the $21^{\text {st }}$ century. Lincoln, NE: AdventSource.

6. Power point presentations on:

- Basics in leadership and management

- Creating vision statement for the church and district

- Initiating change - why? when? how? what?

- Conflict management

- Adaptive change

- Culture and change

- Spiritual formation

- Marketing and change (dealing with methods of advertising)

- Spirit of Prophecy counsels on change

These are some of the topics to be covered during the seminars for pastors at workers meetings. Printed handouts and books for sale will be available during these seminars. In addition, the same materials will be used for the lay leaders during the seminars in districts and churches. 
APPENDIX D

CREATING A STRONG VISION 
CREATING A STRONG VISION (Using Jane Thayer assessment)

\begin{tabular}{|c|c|c|}
\hline Transformation Strategy & Time & Teaching notes/Purpose \\
\hline Stimulating interest & $12 \min$ & $\begin{array}{l}\text { The teacher will show a PowerPoint of a } \\
\text { Bible character on leadership-Moses. } \\
\text { The teacher will find out what the learners } \\
\text { know about the character in the }\end{array}$ \\
\hline Needs Assessment & & $\begin{array}{l}\text { PowerPoint presentation in relation to } \\
\text { leadership. } \\
\text { Exod } 2: 11-15 \\
\text { Gen } 50: 19-20\end{array}$ \\
\hline $\begin{array}{l}\text { Scripture Reading-students } \\
\text { read the texts }\end{array}$ & & $\begin{array}{l}\text { Ps } 86 \\
\text { Isa } 40: 17-24 \\
\text { Isa } 43: 18-21 \\
\end{array}$ \\
\hline Stating the goals & $20 \mathrm{~min}$ & $\begin{array}{l}\text { The teacher will explain the purpose of the } \\
\text { material being presented. } \\
\text { - It is the PRAYER that creates good } \\
\text { vision. } \\
\text { - It is BIBLE STUDY that creates } \\
\text { good vision. } \\
\text { - It is the REFLECTION that gives } \\
\text { good and strong vision. } \\
\text { What needs exist in this congregation? }\end{array}$ \\
\hline Group Discussion & & $\begin{array}{l}\text { Where do we need to change? } \\
\text { What method to use when initiating } \\
\text { change? }\end{array}$ \\
\hline Prayer Time & $10 \mathrm{~min}$ & $\begin{array}{l}\text { Individual silent prayer. } \\
\text { Each learner to listen to God to reveal } \\
\text { ideas about a vision for his or her church. } \\
\text { Have a public prayer in closing. }\end{array}$ \\
\hline Share insights from groups & $10 \mathrm{~min}$ & $\begin{array}{l}\text { Form prayer groups. } \\
\text { Reports from groups. }\end{array}$ \\
\hline Summative Assessment & $3 \mathrm{~min}$ & $\begin{array}{l}\text { The teacher will give a quiz or } \\
\text { questionnaire on the topic presented. }\end{array}$ \\
\hline Total Time & $55 \mathrm{~min}$ & \\
\hline
\end{tabular}


REFERENCE LIST 


\section{REFERENCE LIST}

Allen, R. (Ed.). (2000). The Chambers Dictionary. Edinburgh, Great Britain: Chambers Harrap.

Anderson, L. (1990). Dying for change. Minneapolis: Bethany House.

Anderson, L. (1994). Navigating the winds of change. West Monroe, LA: Howard.

Athony, M., \& Estep, J. (Ed.). (2005). Management essentials for

Christian ministries. Nashville, TN: Broadamn \& Holman.

Bauer, B. L. (2010). Christian worship and cultural diversity: A missiological perspective. In B. L. Bauer (Ed.), Diversity (p.172). Berrien Springs, MI: Lithotech.

Bell, S. (2003). A time to serve: Church leadership for the $21^{\text {st }}$ century. Lincoln, NE: AdventSource.

Bilima, J. D. C. (1993). James Malinki of Malawi: Church leader in cross-cultural ministry (Unpublished doctoral dissertation). Andrews University, Berrien Springs, MI.

Blackaby, H. T., \& King, C. V. (1998). Experiencing God. Nashville: Broadman and Holman.

Block, D. I. (2005). The burden of leadership: The Mosaic paradigm of kingship (Deut 17:14-20). Bibliotheca sacra, 162(647), 259-278.

Boria, B. (2007). Before you introduce change: "Vision casting" isn't step one, or even step two. Leadership, 28(2), 79-81.

Bossert, B. (2007, August 9). Steps to change: Moving toward the new you. Adventist Review, 11.

Bridge, D. (2002). Church discipline. In H. Rowden (Ed.), Church leaders handbook. Carlisle, UK: Paternoster.

Colson, E. C. (1958). The plateau Tonga of Northern Rhodesia. Manchester: Manchester University.

Dabrowski, R., \& Bilima, K. (2000, July 25). Women in the pulpit issue splits congregation in Malawi. Retrieved from http://news.adventist.org/2000/07 /wome-i-the-pulpit-issue-splits-cogregatio-i-malawi.html 
Downing, F.G. (2006). Servant leadership: Jesus and Paul. Journal for study of the New Testament, 28(5), 20-21. doi:10.1177/0142064X0602800528

Dubrin, A. J. (2004). Leadership: Research findings, practice, and skills $\left(4^{\text {th }}\right.$ ed.). New York: Houghton Mifflin.

Elmer, D. (2006). Cross-cultural servanthood: Serving the world in Christian humility. Downs Grove: Intervarsity.

Evison, I. S. (2006). Learning to work the trends. Congregations, 32(1), 27-30.

Flikkema, J. (2009). Promoting the partnership of women in your church: Practical strategies for change. Mutuality, 16(3), 11.

Gangel, K. (2000). Coaching Ministry Teams. Nashville, TN: Word Publishing.

Gashugi, L. (2010). Social and cultural diversity of the Adventist church in Africa. In B. L. Bauer (Ed.), Diversity (p. 86). Berrien Springs, MI: Lithotech.

General Conference Working Policy. (2005-2006). Washington, DC: Review and Herald.

Goldstein, C. (2005, April 28). Cultural Adventists. Adventist Review, 17.

Gove, P. B. (Ed.). (1986). Third New International Dictionary Springfield, MA: Merriam-Webster.

Greenleaf, R. (2002). Servant leadership. Mahwah, NJ: Paulist.

Haffner, K. (2005, June 16). I am the servant leader around here. Adventist Review, 26-27.

Haffner, B., \& Metzger, P. L. (2009). Here we are to worship: Six principles that might bring a true to the age-old tension between tradition and popular culture. Christianity Today, 53(8), 33-35.

Haynes, C. B. (1962). God sent a man. Washington, D.C.: Review and Herald.

Heifetz, R., Grashow, A., \& Linsky, M. (2009). The practice of adaptive leadership. Boston, Massachusetts: Harvard Business Press.

Helm, H. (2009). Hands-on, life-changing learning. FOCUS - the Andrews University Magazine, 45, 24.

Herrington, J., Bonem, M., \& Furr, J. H. (2000). Leading congregational change: A practical guide for the transformational journey. San Francisco, CA: Jossey-Bass. 
Hobgood, W. C. (2001). Welcoming resistance. Bethesda, MD: Alban Institute.

Holberton, P. (2001). Initiating change. Speaking of Leadership, 3(17). Retrieved from http://www.hoberton.com/sol_vol-3-no17.html

Ilo, S. C. (2007). Contemporay African cultural values: A challenge to traditional Christianity. African Ecclesial Review, 49(3-4), 184.

Johnsson, W. G. (2010). A church on the move: Looking back on the past five GC Sessions. Adventist Review, 187(19), 16-18.

Jones, J. (2006). Leading for the future. Congregations, 32(1), 15.

Kaplan, I. (1979). Zambia: A country study. Washington, DC: American University.

Kim, E. M. (2004). Women preaching: Theology and practice through the ages. Cleveland, OH: Pilgrim.

Knott, B. (2006, March 9). Change agents. Adventist Review, 5.

Kohlenberger, J. (2009). Destined to cause the falling and rising of many: Jesus radical treatment of women. Mutuality, 16(3), 4.

Kotter, J. P. (1990). A force for change: how leadership differs from management. New York, NY: The Free Press.

Kouzes, J., \& Posner, B. (2007). The leadership challenge ( $4^{\text {th }}$ ed.). San Francisco, CA: Jossey-Bass.

MacDonald, G. (2005). One small step for a church . ..: One giant lesson about introducing new ideas. Leadership, 26(1), 52-54, 56-57.

Marcionis, J. J. (2009). Society: The basics $\left(10^{\text {th }}\right.$ ed.). Upper Saddle River, NJ: Pearson/Prentice Hall.

Matandiko, C. M. (2001). Seventh-day Adventism in Zambia. Lusaka: Zambia Adventist.

Maxwell, J. C. (Ed.). (2007). The Maxwell Leadership Bible ( $2^{\text {nd }}$ ed.). Nashville, TN: Maxwell Motivation.

Mish, F. C. (Ed.). (2003). Merriam-Webster's Collegiate Dictionary (1 $11^{\text {th }} \mathrm{ed}$.). Springfield, MA: Merriam-Webster.

Moran, R. T., Harris, P. R., \& Moran, S. V. (2007). Managing cultural differences: Global leadership strategies for the 21st century. Burlington, MA: Elsvier Butterworth-Heinemann. 
Muganda, B. G. (2000). Leadership insights for Africans in the twenty-first century. In L. Pollard (Ed.), Embracing Diversity. Hagerstown, MD: Review and Herald.

Ncube, Z. M. (1988). Ancestral beliefs and practices: A program for developing Christian faith among Adventists in Zimbabwe. (Unpublished doctoral dissertation). Andrews University, Berrien Springs, MI.

Ndung'u, N. W. (2008). Cultural challenge and the church in Africa. African Ecclesial Review, 50(1-2), 72.

Neufeld, D. F. (Ed.). (1996). Seventh-day Adventist Encyclopedia (Vol. II). Hagerstown, MD: Review and Herald.

Nichol, F. D. (Ed.). (1976). The Seventh-day Adventist Bible Commentary (Vol. 3). Washington, DC: Review and Herald.

Nichol, F. D. (Ed.). (1978). The Seventh-day Adventist Bible Commentary (Vol. 1). Washington, DC: Review and Herald.

Nichol, F. D. (Ed.). (1978). The Seventh-day Adventist Bible Commentary (Vol. 6). Washington, DC: Review and Herald.

Northouse, P. G. (2006). Leadership: Theory and practice. Thousand Oaks: Sage.

Owens, R. G., \& Valesky, T. C. (2007). Organizational behavior in education: Adaptive leadership and school reform. Boston: Pearson/Allyn and Bacon.

Palmisano, D. J. (2008). On leadership: Essential principles for leadership. New York, NY: Skyhorse.

Pappas, A. C., Pease, E., \& Faramelli, N. (2009). The bivocational congregation: Tomorrow's church? Congregations, 35(1), 12-15.

Paulsen, J. (2009). Things we can't afford to ignore. Adventist World-NAD, 5(12), 13.

Pickett, J. P. (Ed.). (2000). The American Heritage Dictionary of the English Language $\left(4^{\text {th }}\right.$ ed.). Boston, MA: Houghton Mifflin.

Polhill, J. B. (1999). Paul and his letters. Nashville, TN: Broadman \& Homan.

Pollard, L. N. (Ed.). (2000). Embracing diversity. Hagerstown, MD: Review and Herald.

Pue, C. (2005). Mentoring leaders: Wisdom for developing character, calling, and compentency. Grand Rapids, MI: Baker Books. 
Raelly, L. D. (1981). The development of a theological understanding strategy for mission employing small group structure in the SDA church in Zambia (Unpublished DMin. dissertation). Andrews University, Berrien Springs, MI.

Randall, M. W. (1970). Profile for victory in Zambia. South Pasadena, CA: William Carey Library.

Ridley, C. R., \& Goodwin, S. J. (2003). Overcoming resistance. St. Charles, IL: ChurchSmart Resources.

Rogers, E. M., \& Shoemaker, F. F. (1971). Communications of innovations. ( $2^{\text {nd }}$ ed.). New York, NY: Macmillan.

Sahlin, M. (2004). Understanding your community. Takoma Park, MD: Center for Metropolitan Ministry.

Sahlin, M. (2007). Mission in metropolis: The adventist movement in an urban world. Lincolin, NB: Center for Creative Ministry.

Sampley, J. P. (Ed.), (2003). Paul in the Greco-Roman world. Harrisburg, PA: Trinity Press.

Santrac, A. S. (2010). Church and culture: New challenges and a proposal to shape the culture in which we live. Ministry, 82(3), 26-28.

Schaper, D. (2006). Leading from inside out: Spirituality organizational change. Christianity Century, 123(16), 39.

Schmidt, W. (2000). Reading the resistance. Leadership, 21(3), 43-45.

Seventh-day Adventist Church Manual. (17 $7^{\text {th }}$ ed.). (2005). Hagerstown, MD: Review and Herald Association

Shewmaker, S. (1970). Tonga Christianity. South Pasadena, CA: William Carey Library.

Smith, E. W., \& Dale, A. M. (1968). The Ila-speaking peoples of Northern Rhodesia. New Hyde Park, NY: University Books.

Thayer, J. (2008). Teaching for discipleship: strategies for transformational learning (Unpublished class material for students). Andrews University, Berrien Springs, MI.

Vyhmeister, N. J. (2008). Quality research papers for students of religion and theology $\left(2^{\text {nd }}\right.$ ed.). Grand Rapids, MI: Zondervan. 
Watling, T. (2002). 'Leadership' or 'dialogue'? Women, authority and religious change in a Netherlands community. Sociology of Religion, 63(4), 515-538.

Weems, L. H. J. (2003). Take the next step: Leading lasting change in the congregations Nashville: Abingdon.

White, E. G. (1896). Letter, 81, 3. (Unpublished material). Battle Creek, MI.

White, E. G. (1903, April 14). Review and Herald.

White, E. G. (1911). Acts of apostles. Boise, ID: Pacific Press.

White, E. G. (1915). Gospel workers. Hagerstown, MD: Review and Herald.

White, E. G. (1940). Desire of ages. Boise, ID: Pacific Press.

White, E. G. (1948). Testimonies for the church. (Vol. 1). Boise, ID: Pacific Press.

White, E. G. (1958). Patriarchs and prophets. Boise, ID: Pacific Press.

White, E. G. (1962). Testimonies to ministers and gospel workers. Boise, ID: Pacific Press.

White, E. G. (1974). Sketches from the life of Paul. Hagerstown, MD: Review and Herald.

White, E. G. (1983). The publishing ministry. Hagerstown, MD: Review and Herald.

Wood, A. S. J. (1961). Northern Rhodesia: The human background. London, Great Britain: Pall Mall Press.

Youngblood, R. F. (Ed.). (1986). Nelson's new illustrated Bible dictionary. Nashville, TN: Thomas Nelson.

Zambia culture. (2009). Retrieved from http://www.mapsofworld.com/zambia/culture/women.html

Zambia women. (2009). Retrieved from http://www.mapsofworld.com/zambia/culture/women.html 
VITA 
VITA

Name: Edwin Shimunzhila

Date of Birth: February 16, 1956

Place of Birth: Namwala, Shimunzhila Village, Zambia

Married: November 18, 1979 to Beauty Kalinda Moonga

Children: Mainza, (1980), Maangwe, (1982), Moonga, (1984) and Mutobwe, (1986)

\section{Education:}

2009-2011 DMin in Leadership at Andrews University

2005-2008 MDiv from SDA Theological Seminary, Andrews University

1992-1995 Andrews University (Solusi Campus, Zimbabwe) - BA in Theology

1981-1982 Rusangu Ministerial School, graduating with a Diploma

1972-1976 Namwala Secondary School

1965-1971 Kantengwa Primary School

\section{Ordination:}

03/08/1989 Ordained to the SDA Gospel Ministry

\section{Experience:}

2004-2005 Lusaka, Zambia Union Conference Youth/Personal Ministries Director

2002-2004 Lusaka, Central Zambia Conference Church/District Pastor

2000-2001 Kabwe, Central Zambia Conference Executive Secretary

1996-2000 Kabwe, Central Zambia Conference Youth//Communication Director

1985-1992 Lusaka, Zambia Union Conference Youth/Personal Ministries Director

1984-1985 Monze, South Zambia Conference Youth/Sabbath School Director

1982-1983 Livingstone, South Zambia Conference District Pastor

1979 Namwala, South Zambia Conference District Literature Evangelist 